\title{
PROTECTING MINORITY SHAREHOLDERS IN CIVIL AND COMMON LAW SYSTEMS: CANADIAN, UKRAINIAN AND GERMAN EXAMPLES
}

Iushchenko Igor Sergiiovych

Submitted in partial fulfilment of the requirements for the degree of Master of Laws

at

Dalhousie University

Halifax, Nova Scotia

August 2012

(C) Copyright by Iushchenko Igor Sergiiovych, 2012 


\title{
DALHOUSIE UNIVERSITY \\ SCHULICH SCHOOL OF LAW
}

\begin{abstract}
The undersigned hereby certify that they have read and recommend to the Faculty of Graduate Studies for acceptance a thesis entitled "PROTECTING MINORITY SHAREHOLDERS IN CIVIL AND COMMON LAW SYSTEMS: CANADIAN, UKRAINIAN AND GERMAN EXAMPLES” by Iushchenko Igor Sergiiovych in partial fulfilment of the requirements for the degree of Master of Laws.
\end{abstract}

Dated: 22 August 2012

Supervisor:

Professor Sarah Bradley

Reader:

Professor Geoffrey Loomer

Examiner:

Professor Michael Deturbide 


\title{
DALHOUSIE UNIVERSITY
}

DATE: 22 August 2012

\begin{abstract}
AUTHOR: Iushchenko Igor Sergiiovych
TITLE: $\quad$ PROTECTING MINORITY SHAREHOLDERS IN CIVIL AND COMMON LAW SYSTEMS: CANADIAN, UKRAINIAN AND GERMAN EXAMPLES
\end{abstract}

DEPARTMENT OR SCHOOL: Schulich School of Law

DEGRE: LLM CONVOCATION: October $\quad$ YEAR: 2012

Permission is herewith granted to Dalhousie University to circulate and to have copied for non-commercial purposes, at its discretion, the above title upon the request of individuals or institutions. I understand that my thesis will be electronically available to the public.

The author reserves other publication rights, and neither the thesis nor extensive extracts from it may be printed or otherwise reproduced without the author's written permission.

The author attests that permission has been obtained for the use of any copyrighted material appearing in the thesis (other than the brief excerpts requiring only proper acknowledgement in scholarly writing), and that all such use is clearly acknowledged.

Signature of Author 


\section{DEDICATION PAGE}

This thesis is dedicated to the closest and most valued people for me - my parents, Sergii Iushchenko and Nina Iushchenko, and my brother Vyacheslav Yushchenko. 


\section{TABLE OF CONTENTS}

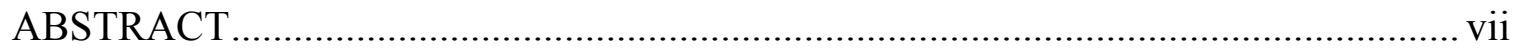

LIST OF ABBREVIATIONS USED ................................................................. viii

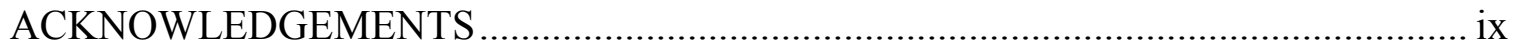

CHAPTER I INTRODUCTION ........................................................................ 1

CHAPTER II FUNDAMENTAL ISSUES ....................................................... 7

2.1 Why Do We Need to Protect Shareholders? ............................................ 7

2.2 A Controlling Shareholder: Advantageous or Not? ............................... 11

2.2.1 Advantages of Having a Controlling Shareholder............................. 12

2.2.2 Negative Aspects of the Existence of a Controlling Shareholder in a

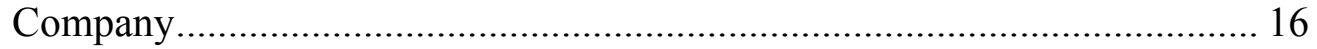

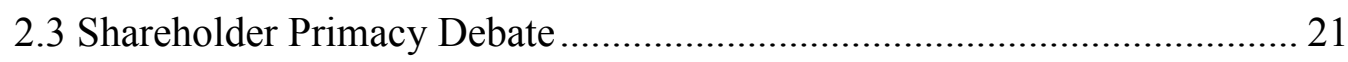

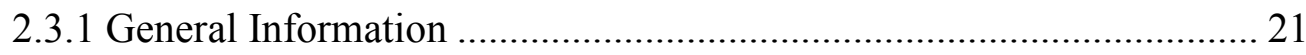

2.3.2 Berle and Means on Shareholder Primacy ...................................... 23

2.3.3 Dodd's Position: Support for Corporate Social Responsibility ............ 30

2.3.4 An Argument for Shareholder Primacy over Corporate Social Responsibility ............................................................................... 35

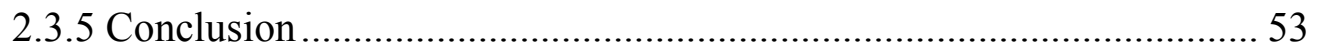

CHAPTER III SHAREHOLDER PROTECTION IN CIVIL LAW COUNTRIES:

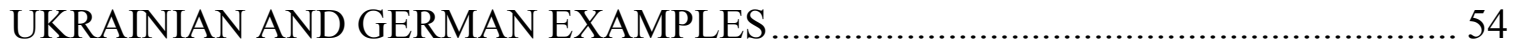

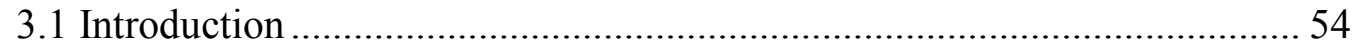

3.2 Private Companies in Ukraine and Germany: General information ........... 56

3.3 Protecting Minority Shareholders in Ukraine and Germany ..................... 67 


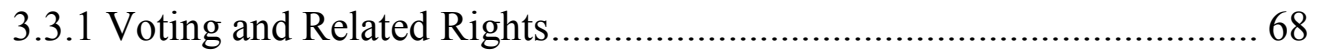

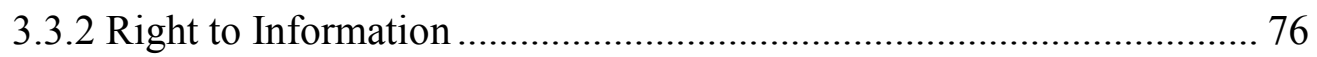

3.3.3 Withdrawal from the Company .......................................................... 79

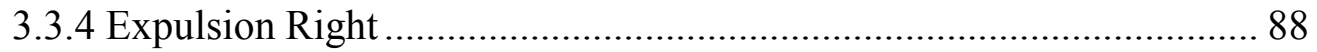

3.3.5 Dissolution of a Company ................................................................... 97

3.3.6 Derivative Action (Suit) and Direct Action.......................................... 101

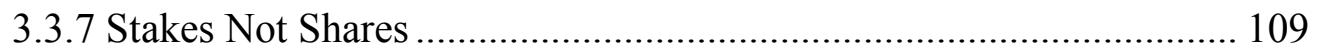

3.4 Shareholder Protection under Civil Law: A Summary of Problems......... 115

CHAPTER IV THE SOLUTION: SHAREHOLDER PROTECTION IN THE

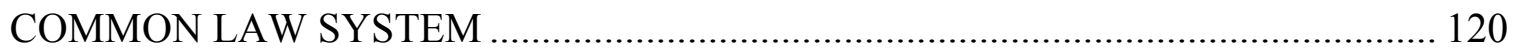

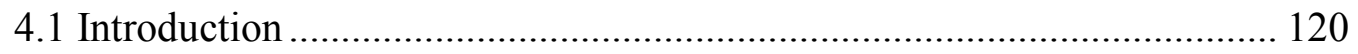

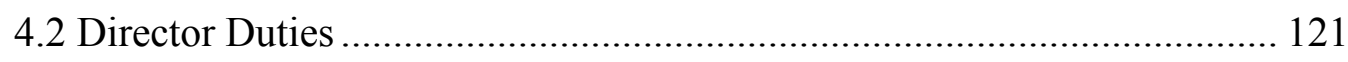

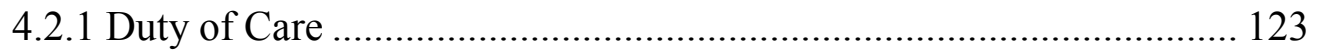

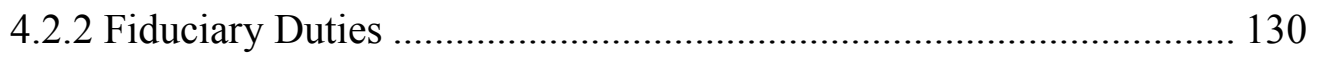

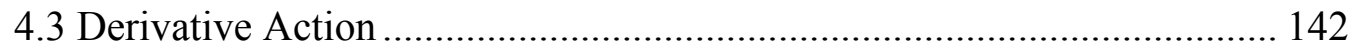

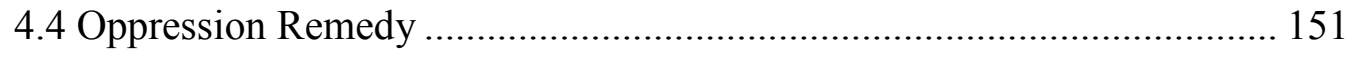

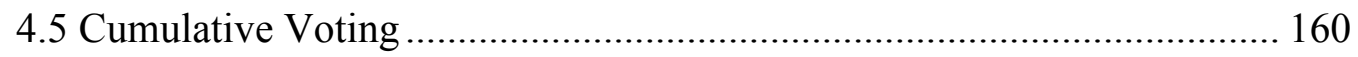

4.6 Obstacles to Implementing Common Law Remedies in a Civil Law

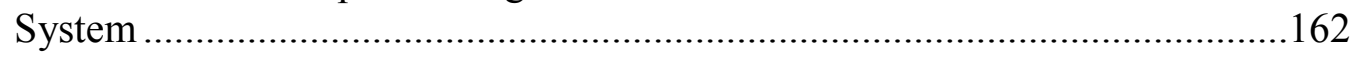

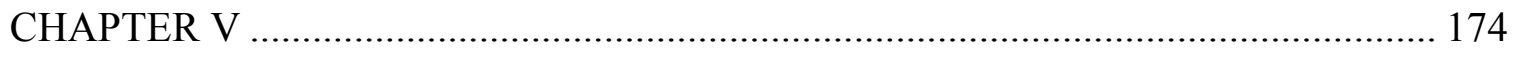

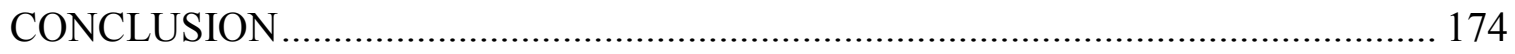

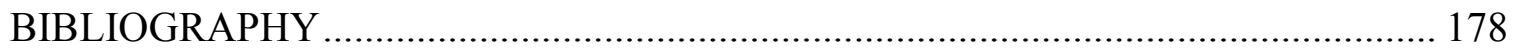




\begin{abstract}
This thesis analyses minority shareholder protection in common law and civil law systems. Principally, this is done by examining closely-held corporations created under Canadian, Ukrainian and German laws. It examines minority shareholder protection by critically analyzing voting and related rights, the right to information; withdrawal from the company, expulsion right, the dissolution of a company, derivative action and direct action. The thesis also summarizes problems in the civil law system that cannot be solved in favor of minority shareholders. In addition to the above-mentioned, it provides possible solutions to the problems of minority shareholder protection in the civil law system, that is, methods by which to increase protection for minority shareholders against the majority and/or directors. Specifically, it focuses on cumulative voting, common law director's duties, derivative action and the oppression remedy. Moreover, this thesis analyzes the possibility of incorporating some institutions into civil law legislation and considers obstacles to implementing them.
\end{abstract}




\section{LIST OF ABBREVIATIONS USED}

$\begin{array}{ll}\text { BGB } & \text { Civil Code of Germany or Burgerliches Gezetzbuch } \\ \text { CBCA } & \text { Canada Business Corporation Act } \\ \text { CEO } & \text { Chief Executive Officer } \\ \text { FGS } & \text { Faculty of Graduate Studies } \\ \text { GmbH } & \text { Gesellschaft mit beschränkter Haftung or Limited Liability Company } \\ \text { Hrn } & \text { Hrivna } \\ \text { IPO } & \text { Initial Public Offering } \\ \text { LLM } & \text { Master of Laws } \\ \text { TOV } & \begin{array}{l}\text { Tovarystvo z Obmezhenoyu Vidpovidalnistyu or Limited Liability } \\ \text { Company }\end{array}\end{array}$




\section{ACKNOWLEDGEMENTS}

I would like to take this opportunity to express my deepest gratitude to the people that made this thesis possible. My sincere thanks are to my supervisor, Professor Sarah Bradley, for introducing me to Canadian Business Associations and Securities Regulation laws, sharing useful thoughts and comments on every draft of this paper and exceptionally valuable advice in guiding the research. Moreover, thanks to her very much for always finding time for meetings with me, despite her busy schedule. I will always remember it and always will be indebted to her. It is my honor to present this thesis to her, and I could not have asked for a better supervisor.

To Professor Geoffrey Loomer, for giving the recommendations on how to improve my thesis and also for providing comments on the final draft of my paper.

To David Dzidzornu, for his extremely valuable help in editing of the thesis and providing comments regarding the paper.

To Michelle Kirkwood, for helping in all organizational issues.

On a personal note, I am grateful to my family for support during my research. Because of them, I have been able to come to Canada and pursue this degree.

I wish to all of you strong health, happiness, success in all initiatives that you undertake and all the best. Live long and be well. 


\section{CHAPTER I}

\section{INTRODUCTION}

Today, it is hard to imagine life without corporations ${ }^{1}$. Corporations have become more than artificial persons. They are the biggest employers, the biggest taxpayers and the biggest holders of assets in the world ${ }^{2}$. In light of their importance to national and global economies, governments and influential non-governmental institutions should pay attention to their protection and the protection of their members.

The central debates relating to corporate governance over the past century have asked: who should control the corporation and who should receive its profits? Who should be liable for its misconduct, who should carry the risk of its losses, and who should be protected? In this paper, these questions are examined in detail, and the case is made that the probable answer to all of these questions is the shareholders of a corporation.

There are several reasons for this conclusion. The economic contribution that corporations make to society cannot be overstated. The profits generated by corporations are significant to tax revenue, economic growth and a country's overall welfare. Corporations are principally governed by their shareholders and directors. Shareholders

${ }^{1}$ In this thesis the terms corporation and company are used interchangeably.

${ }^{2}$ See, for example United Nations Conference on Trade and Development, World Investment Report 2012: Towards a New Generation of Investment Policies, online: UNCTAD $<$ http://unctad.org $>$. 
invest money in a corporation with a view to receiving profits in the future and protection of their economic position is essential for investors. Therefore, in order to maintain investor confidence and increase investment, governments should make efforts to protect both majority and minority shareholders.

Shareholders' control over a corporation exists due to the rights they are granted by the corporation's enabling statute and constating documents. But these rights are only as meaningful as the mechanisms in place to protect them. Although in many countries shareholders have significant legal rights, the realization of these rights in some situations is difficult and problematic. In regard to minority shareholders, the difficulty is due to the "Majority rule" principle which puts them in a disadvantaged position in comparison to majority shareholders. Challenges of how to protect minority shareholders from exploitation by the majority, how to protect shareholders from wealth extracts by directors, and how to provide real participation in corporate management to minority shareholders, are the most common problems in the modern regulation of corporate affairs.

This thesis analyses minority shareholder protection in common law and civil law systems. Principally, this is done by examining closely-held corporations created under Canadian, German and Ukrainian laws. The reasons for the focus on closely held corporation are as follows. First, this form of legal entity is by far the most common in 
the aforementioned countries ${ }^{3}$. Second, there is no market for shares of such corporations, which puts a minority shareholder in the disadvantageous position of being unable to simply sell his or her shares. Third, from a theoretical point of view, it is easier to show protection for a minority in a closely-held corporation than in a widely-held corporation. Because of the large number of shareholders, the many remedies that exist are almost impossible to take advantage of because of the cost of doing so. Finally, a widely-held corporation has to fulfill security regulation requirements which provide more protection for shareholders than those of closely-held corporations.

The reasons the three principal countries, Canada, Ukraine and Germany were selected for analysis as follows. First, it provides a comparison between the world's two principal systems of law. Canada is a common law country, while Ukraine and Germany belong to the civil law family of nations. A substantial body of research indicates that common law countries offer superior shareholder protection ${ }^{4}$ when compared to civil law countries. ${ }^{5}$ Second, these countries have very different systems of shareholder protection.

3 According to the State Statistics Committee of Ukraine, on March 1st 2011, 1,301,495 entities were registered, 1,245,321 of which have the status of a legal entity, and 56,174 that do not. Of these, Limited Liability Companies (TOV) number 447,979. There are also 286,174 Private Enterprise, and 28,415 Joint Stock Companies. Regarding Germany, on January 1st 2005, "some 975,000 German commercial entities were organized as a GmbH”. In comparison with this number, the AG (Joint Stock Company) constitutes 15,000. See Klaus Muller, The GmbH: A Guide to the German Limited Liability Company, 3d ed (Germany: Beck; Kluwer Law International, 2006) at 4.

${ }^{4}$ See for example, R La Porta et al, "Law and Finance" (1998) 106 J Pol Econ 1113.

${ }^{5}$ Udo Braendle, "Shareholder Protection in the USA and Germany - "Law and Finance" Revisited”, (2006) 7:3 German Law Journal 257 at 260. 
Canada has been recognized for having one of the best shareholder protection regimes in the world, whereas Ukraine and Germany are ranked among the worst, according to the World Bank's ranking ${ }^{6}$. This ranking measures the strength of minority shareholder protection against directors' misuse of corporate assets for personal gain. The indicators distinguish three dimensions of investor protections: transparency of related-party transactions; liability for self-dealing; and shareholders' ability to sue officers and directors for misconduct. The data for the ranking come from a survey of corporate and securities lawyers and are based on securities regulations, company laws, civil procedure codes and court rules of evidence. ${ }^{7}$

The task of this thesis is first to analyze legislation, case law and scholarly works on mechanisms of protection for minority shareholders in common law countries (mainly based on Canadian law), and in civil law countries (based on Ukrainian and German law). Second, based on theory and practice, the thesis seeks to provide an answer to the question which system offers superior protection to minority shareholders. Finally, the thesis provides possible ways to deal with some of the deficiencies in the protection of minority shareholders in civil law countries.

This thesis has five chapters. Chapter I is the introduction. Chapter II begins by posing the question why minority shareholders must be protected. It discusses the

\footnotetext{
6 Doing Business, Economy rankings, online: Doing business $<$ http://www.doingbusiness.org $>$.

${ }^{7}$ Ibid.
} 
significance of majority and minority shareholders and examines the possible advantages and disadvantages of having a controlling shareholder, and what the minority can expect from him/her. This chapter also pays attention to the main role of the corporation by examining the concepts of shareholder primacy and corporate social responsibility. It concludes with the argument that preference should be given to shareholder primacy.

Chapter III considers shareholder protection in civil law countries based on Ukrainian and German law. This Chapter starts with a brief historical background to Ukraine and Germany, their corporate law, and general information on private companies established there. It then examines minority shareholder protection by critically analyzing voting and related rights, the right to information, withdrawal from the company, expulsion right, the dissolution of a company, derivative action (suit) and direct action. The chapter concludes by summarizing problems in the civil law system that cannot be solved in favor of minority shareholders.

Chapter IV provides possible solutions to the problems of minority shareholder protection in civil law systems, that is, methods by which to increase protection for minority shareholders against the majority and/or directors. This chapter focuses on how cumulative voting, common law director's duties, derivative action and the oppression remedy can help to achieve this objective. Moreover, it analyzes the possibility of incorporating these institutions into civil law legislation and considers obstacles to implementing them. 
Part V concludes by summarizing the main ideas put across regarding minority shareholder protection, and argues that it is worth adopting some remedies from the common law countries in order to develop civil law minority shareholder protection. 


\section{CHAPTER II}

\section{FUNDAMENTAL ISSUES}

\subsection{Why Do We Need to Protect Shareholders?}

In general, countries have a concern about investment. Investments produce workplaces and infrastructure (buildings, roads, networks and so forth), which eventually lead to higher tax revenue, and also positively reflect on the public image of a country.

Each shareholder is an investor, no matter if he or she invests one dollar or several million dollars. That is why his or her position should be important to the company and to policy makers. In real life, however, because of the "majority rule", which means that the right or power to control a corporation rests on majority shareholders, a minority shareholder is in a disadvantageous position. According to s. 2 (3) of the Canada Business Corporation Act (hereinafter $\left.C B C A^{8}\right)$ :

a body corporate is controlled by a person or by two or more bodies corporate if

- $\quad(a)$ securities of the body corporate to which are attached more than fifty per cent of the votes that may be cast to elect directors of the body corporate are held, other than by way of security only, by or for the benefit of that person or by or for the benefit of those bodies corporate; and

- $\quad(b)$ the votes attached to those securities are sufficient, if exercised, to elect a majority of the directors of the body corporate.

${ }^{8}$ Canada Business Corporation Act, RSC 1985, c C-44 at s 2(3) [CBCA]. 
Usually, in light of the small number of shareholders in a closely-held corporation, s. 2 (3) (b) is not often applied and, thus, a shareholder who owns 50 percent plus 1 vote, or in some cases 66.6 percent plus one vote ${ }^{9}$, can make any decisions without taking the minority's opinions into consideration ${ }^{10}$. Because of this rule, it is clear that the majority is able to exploit its rights and place the minority in a disadvantageous position. This happens because of the nature of the corporation and the purpose of the corporation (this question will be analyzed more depth in the next part).

Usually, people carry out business activities for two essential reasons: "producing the maximum benefit from the activity for themselves and reducing the risk arising out of the activity" ${ }^{11}$. In order to reduce risk, which in our case is liability, the government provides for different types of companies with limited liability, as developed by all legal systems. The prevailing form of corporation in Canada is the closely-held corporation. In Germany, it is the Gesellschaft mit beschränkter Haftung $(\mathrm{GmbH})$ that is, the Limited Liability Company. In Ukraine, it is the Tovarystvo z Obmezhenoyu Vidpovidalnistyu (TOV), also referring to Limited Liability Company. GmbH and TOV are civil law equivalents of a closely-held corporation.

${ }^{9}$ In the case when a special resolution is required. See for example, $C B C A$, supra note 7, s.2 (1).

${ }^{10}$ It needs to be noted that this statement does not hold true in every situation. For example, this is not true in the situation of fundamental changes.

${ }^{11}$ Daniel Szentkuti, Minority shareholder protection rules in Germany, France and in the United Kingdom: A comparative overview (LLM Thesis, Central European University, 2007) [unpublished] at 6. 
Producing maximum benefit from activity, which is the second essential reason for doing business, means that a shareholder expects some remuneration from the corporation for the risks which he or she takes. This remuneration can be expressed in the forms of salary, bonus, dividend, and so forth.

Because of the focus on wealth maximization, many problems arise between shareholders and director(s). This usually happens when there is a controlling shareholder in a corporation. Such a shareholder often supports his or her own interests and disregards the interests of the minority. Moreover, he or she may act in his or her own interests at the expense of the minority.

It is important to know that a well-functioning company serves not only the interest of the owners, either individually or as a group, but also provides job opportunities to employees, provides services to people and pays tax to support the national budget ${ }^{12}$. Shareholder abuse can lead to the dissolution of a corporation, which means "losing a functioning economic unit from the national macroeconomic aspect"13. Moreover, in light of recent developments, such as the global financial crisis, the public is losing faith in banks and is, therefore, investing less money in financial institutions ${ }^{14}$. It

\section{${ }^{12}$ Ibid at 8 . \\ ${ }^{13}$ Ibid.}

${ }^{14}$ This does not concern Canada and Germany, as much as it concerns Ukraine. Because of the crisis, people who had deposits in Ukrainian banks simply could not withdraw their deposit (money), because the National Bank of Ukraine issued a document which prohibited returning deposits in order to save the banking system. Moreover, historically the older generation does not believe banks, as after the 
is known that the worst situation for an economy is when the public does not spend its money and, instead, keeps it in their pockets. Money has to be in a turnover. That is why governments are interested in creating rules that work not only for big investors, but also for small investors who are usually in the position of minority shareholders. More importantly, those rules also protect the different interests within a company and support stable corporate operation.

It is also fair to protect the minority shareholder. Laws should protect all shareholders, not only the majority, but also the minority. This is because all shareholders are vested with the same power and rights, whether someone invests one dollar or one million dollars, or holds one per cent or 99 percent of the shares. The only difference is that their rights are realized differently. Moreover, most people cannot invest enough to be in a position of the controlling shareholder of a company. Thus, because of the money disparity, a minority shareholder, usually, is not able to compete on an equal level with majority shareholders without the assistance of governments and courts. In this case, the judiciary and legislation balance power between the minority and the majority.

To sum up, the protection of shareholders is needed to ensure economic growth, expand capital markets, increase employment and provide fairness. Investments are crucial for a country to function (economical aspect) and since they are crucial to the

disintegration of the USSR all the monies that people had in the USSR Bank were lost and Russia has not compensated them for even a cent. 
country, the investors, who, in most cases, are shareholders, should be protected (legal aspect and fairness).

\subsection{A Controlling Shareholder: Advantageous or Not?}

Before examining minority shareholder protection, it is important to consider the positive and negative aspects of having a controlling shareholder ${ }^{15}$. This is important for three reasons. First, it helps to explain how the majority can abuse the rights of the minority. Second, it helps to focus on the bigger problems of the minority, solutions to which are essential for them and for a company's interest. Finally, it helps to show that a government should not blindly support the minority over the majority shareholders because, in many situations, a controlling shareholder may bring positive contribution to a corporation.

A controlling shareholder can be one person, or it can be represented by a group related to each other (family, several companies which are controlled by the same person). Having minority and majority shareholders in a privately-owned corporation is a common situation in Canada, Ukraine and Germany.

${ }^{15}$ Controlling shareholders are those with enough shares under their control to dominate or strongly influence the board of directors and, therefore, to choose management. 
In common international practice the existence of a controlling shareholder can, and usually does, lead to a lowering in the ranking of a company ${ }^{16}$. But the controlling shareholder can also bring a corporation certain advantages.

\subsubsection{Advantages of Having a Controlling Shareholder}

\section{A "real owner" of the company}

A controlling shareholder presents as a "real owner" of the company. This is an advantage for a company because of the possibility of concentrating resources to apply to areas prioritized by a controlling shareholder. There is no need to persuade many persons regarding strategic decisions. In this situation, a controlling shareholder becomes a de facto owner of the company and decides the direction the company will go in. This presents key possibilities for the operation of the company.

Correlation between the economic interests of a controlling shareholder and a company

If one were to consider a controlling shareholder as an economically rational person, it would be right to assume that he or she tends to increase his or her own fortune ${ }^{17}$. Generally, this is not the same as increasing the market value of the company.

16 This mainly concerns a company which wants to initiate an IPO. See, for example, the general rules to assess a company by Standard and Poor's, Rating criteria, online: Standard and Poor's <http://www.standardandpoors.com>.

17 Hadiye Aslan, Controlling Shareholders and the Agency Cost of Debt: Evidence from Syndicated Loans, online: Social Science Research Network $<$ http://www.ssrn.com> at 5 . 
However, as the shareholder retains control in a corporation, the shareholder can increase his or her own fortune from increasing corporate value, which reflects positively also on the minority.

\section{Great involvement in management}

It is common that a controlling shareholder would occupy the position of a general manager of a corporation. In this case, ownership is combined with management. For a company which is in its infancy, this situation is not only common, but also quite usual. Until the company obtains sufficient capital, even current or routine bargains may lead to catastrophic results. Thus, to deal with these risks, a controlling shareholder takes on managerial functions. With capital growth, fatal risks move into the area of strategic decisions and strategic investments. This is why it becomes natural for the shareholder to leave day-to-day control and to concentrate his or her attention on strategic questions through the general meeting.

Also, a controlling shareholder works with management much more closely than other shareholders. This reduces the risk that management would make poorly thought and groundless decisions.

\section{Strengthening control under management and safety of assets}

A controlling shareholder is usually more careful and observant than the management and minority shareholders because the price of mistakes is much higher for 
him of her ${ }^{18}$. A majority shareholder reacts violently to the threat of losing assets and can be very effective in defending a company (though mainly in widely-held corporations regarding takeover).

Possibility of additional investments in company development, and additional support for the company at a time of crisis

The World Financial Crisis showed that many shareholders took risks by taking loans for themselves in exchange of pledges, and gave the money to the company in order to save it. This can mainly be performed by controlling shareholders, because in most cases only they are able to find or borrow a substantial amount of money which could help a corporation to pay debts and, accordingly, remain operational.

\section{Public image and reputation ${ }^{19}$}

Information on who is a controlling shareholder and who, per se, is the owner of a business, becomes more accessible. This information may attract the attention of the public and press, thereby shaping the shareholder's public image. Human psychology may then start working such that the shareholder would desire to gain public success, acknowledgement and respect. These factors might motivate a controlling shareholder to develop the corporation's business.

18 Jose Miguel Mendoza, The Controlling Shareholder as Reputational Intermediary, online: Saïd Business School, University of Oxford $<$ http://www.sbs.ox.ac.uk/centres/reputation/Documents/10-302The $\% 20$ Controlling\%20Shareholder\%20as\%20Reputational\%20Intermediary.pdf $>$.

${ }^{19}$ Ibid. 
The personality of a controlling shareholder, frequently, directly influences a company's reputation. It is known that the reputation of a company is very important for its operations and in many cases, plays the biggest role in choosing contractors, consumers or customers. Reputation is especially significant for professional firms, such as law, accounting, auditing, travel, stock exchanges, underwriters and so on. The importance of reputation can be seen in the example of audit firms. Almost all the international auditor market is controlled by the "Big Four" 20 . This is mainly because of their reputations, which they developed through many years of high level service to their clients.

\section{Possible interest in expanding the corporation through an IPO ${ }^{21}$}

Initiating an Initial Public Offering allows the majority not only to receive additional funds without loss of management, but also to evaluate the market price of a corporation and to increase liquidity of shares. Moreover, ownership of a control block of shares might be deemed prestigious. A good example is Facebook Inc ${ }^{22}$. Before 2012, the company was privately owned by Mark Zuckerberg and other founders. On May $18^{\text {th }}$ 2012, the stock market began selling its shares. From a small private company, Facebook turned into a large international corporation. By using Facebook as an example, we see

${ }^{20}$ The name of the 4 biggest audit firms in the world are PricewaterhouseCoopers, Deloitte Touche Tohmatsu, Ernst \& Young, KPMG.

${ }^{21}$ Initial Public Offering.

${ }^{22}$ Shayndi Raice, "Facebook Sets Historic IPO", online: The Wall Street Journal $<$ http://online.wsj.com>. 
how controlling shareholders helped to promote the company and eventually helped minority shareholders, since the value of the company dramatically increased.

\subsubsection{Negative Aspects of the Existence of a Controlling Shareholder in a Company}

A controlling shareholder can bring not only advantages to a company, but also risks for other shareholders and the company itself. The potential risks are:

\section{Risk of ill-considered decision-making}

Often while trying to achieve more substantial results, a controlling shareholder may initiate questionable business projects. Since he or she possesses the controlling packet of shares, a majoritarian shareholder, as a rule, can insist on moving forward with that kind of a project. This can lead to negative consequences. Generally, excessive closeness between the controlling shareholder and management, and the shareholder's involvement in the direction of business, can play both positive and negative roles. A sole director, who is appointed by a controlling shareholder, would take the majority's opinion into consideration very carefully, and would usually not propose something else that may be better for the company. In this situation, a director of the company is an executor of someone's ideas, but not a creator of such. He or she becomes the top executor rather than the top manager, not a leader of the company, but rather a "puppet" in the controlling shareholder's arms. 
The above-mentioned risk is increasing, especially in situations where the controlling shareholder is appointed to the position of an executive director. The shareholder might eventually feel like he or she is in possession of unlimited and absolute power in a company and, therefore, start thinking that he or she cannot be wrong, an attitude that might lead to fatal consequences for the business.

Egoistical (selfish) interest, disregard of other stakeholders' interests, and attempt to receive additional (subsidiary) income at the expense of other members

It is not a secret that a human being is selfish by nature. Most of the time he/she puts his or her own interests before those of others. This scenario is prevalent in corporate relationships.

This can happen when a majority shareholder ignores the interests of the minority and refuses to pay dividends. Meanwhile, for the minority in a closely-held corporation, there is no stock market for shares, and dividends are usually their only source of profit. The owner, who can always sell stakes easily, because per se, he/she sells the whole business $^{23}$, often prefers not to share the profit with others, but to use it for developing the company. At the same time, the shareholder may raise his or her salary and hire his or her relatives, friends or trusted persons as his or her counselors, with salaries substantially exceeding his or her own. Another widespread method for a shareholder's selfenrichment, which is more common in countries like Ukraine and Russia, is to sell the

${ }^{23}$ Ronald J Gilson \& Jeffrey N Gordon, Controlling Controlling Shareholders, online: Social Science Research Network <http://papers.ssrn.com> at 4. 
assets of a corporation to another company for an undervalued price ${ }^{24}$. Usually, the other company is also owned or controlled by the majority shareholder. In other words, this shareholder may concentrate profits outside the corporation. In those countries, the aforementioned scheme works for the director and the controlling shareholder because he or she does not owe fiduciary duties and the director is protected because his or her decision to sell the assets is usually approved by a majority of the shareholders.

\section{Desire to strengthen personal control}

Controlling shareholders may desire to strengthen their control in a corporation. There are many reasons for this. One is to obtain a special majority ${ }^{25}$ of votes. In this case, the controlling shareholder can make almost any resolution without considering the

opinion of the minority. ${ }^{26}$ Another reason, which is important in Ukraine and Russia, is to protect a company from seizure by the minority and/or outsiders, also called "raider attack" and "greenmailing" and so on. Such a seizure is much easier to accomplish if a minority exists within a company. These attacks from the outsider can be completely legal, such as when it is done to invalidate contracts by which the controlling shareholder obtained majority votes. It is considered somewhat legal (half legal) when an outsider, because of his/her connections, incites actions in the form of, for example, inspections by

${ }^{24}$ Ibid. See also Simon Johnson et al, “Tunneling” (2000) 90 Am Econ Rev 22.

${ }^{25}$ In this thesis special majority votes means possession of $2 / 3$ or $3 / 4$ of the votes or the subscribed capital, which requires passing a special resolution.

${ }^{26}$ An exception is when fundamental changes to the company are to be made. 
tax officials, the police, prosecutors, sanitary officials and others, during which a company is not able to work normally; or when an outsider "helps" to open a criminal case regarding the shareholder or his/her relatives. This cynical action is captured in the expression: "There is always a fitting law for a fitting person" 27 . Usually after such actions, the controlling shareholder sells his or her shares for a "peanut" in order to stop the inspections or to close the criminal case in order to avoid the last possible scenario: total criminal seizure of the company. That seizure happens when dozens of men block the entrance of a corporation's premises while showing documents that state that yesterday there was a general meeting and/or the CEO made a resolution by which a new "lawful" CEO was elected. This "newly-made CEO" takes all the documents and leaves the company. Without the director, stamps and documents, a company simply is not able to carry out any transactions or sign any contracts. Then the shareholders try to find the "newly-made CEO" and are ready to share stakes with him or her in order to save the company. This last scenario resembles a Hollywood movie; however, it happens in this day and age in Ukraine and Russia.

The problems with selling a controlling packet of shares and inheritance of the business

While making a decision to purchase stakes in a company, an investor takes into consideration the risks connected to the possible presence of a controlling shareholder. However, the majority shareholder has the right to sell his or her stakes at any time, and

27 This was commonly said in the USSR. 
usually he or she cannot be restricted by articles of association of the company. Furthermore, the controlling shareholder can sell his/her shares at a premium a value compared to what non-controlling shares may sell for ${ }^{28}$. "The existence of an ongoing stream of private benefits increases the value of the controlling shares compared to the non-controlling shares by the present value of the future private benefits" ${ }^{29}$

It is not different for a minority shareholder who will become a new controlling shareholder of a company, and what purposes he/she is pursuing. This shareholder may be an outsider who may wish to sell the company for the reason of the interests of the new owner. The purchaser can possibly be a competing company or a consumer company interested in lowering the prices of produced goods, a move that can lead to risks of losing profit. Moreover, there are many other possible negative scenarios associated with purchasing a control block of stakes from an outsider.

The inheritance of a business by heirs due to the death of the controlling shareholder can bring similar risks. The heirs may not have enough experience and knowledge to run the company. They may have disagreements among themselves and this can allow an outsider or minority to seize control of the company. They may also want to sell the company. There are other risks and problems, which may lead to negative consequences for a minority and for a company.

\footnotetext{
${ }^{28}$ Ronald J Gilson \& Jeffrey N Gordon, supra note 23 at 4. ${ }^{29}$ Ibid.
} 
Generally, a company in which the controlling shareholder is also the CEO is very vulnerable because losing the controlling shareholder also leads to losing the main manager. In that case the company has to solve two problems simultaneously: ownership and managerial succession. If a company does not have a board of directors (as a rule, the shareholder in control is not obligated to form a board of directors and usually does not deem it necessary), it automatically loses all control bodies. In this situation, it is very likely that the company will be dissolved.

The aforementioned disadvantages result in risks for minority shareholders, potential investors and other stakeholders. As can be seen, the majority in a company can bring not only additional opportunities, but additional risks as well. Thus, a controlling shareholder has to realize that he or she is responsible not only for his or herself, but also for the minority shareholders, other stakeholders and the company itself. Therefore, it is important to know how a minority is able to protect itself and the company.

\subsection{Shareholder Primacy Debate}

\subsubsection{General Information}

The previous part, on the relationship between shareholders, showed that along with advantages, the majority shareholder can abuse the rights of a minority. A director also can be another source of oppression for a minority. Thus, before analyzing minority shareholders' protection, it is necessary to focus on role of a corporation and its best interest. This issue is important, as different approaches say that a director's duties differ between constituencies, and that this obliges them to act differently to suit the best 
interest of a corporation. Furthermore, interpretation of the concept of "the best interest of the corporation" gives rise to the practical problem as to what the directors' duties are and how they have to carry them out. In other words, directors' duties may substantially vary depending on whether preference is given to one conception over another in how those duties are viewed.

In the early 1930 s, there was a lively debate "between two preeminent corporate scholars $" 30$ on the question of the purpose of a corporation. This debate is so important and complicated that even after almost a century, there has not emerged a sole approach to solving the issue the debate is about. "The beating heart of the [debate] is the question of what it means to act "in the best interest of corporation'."31

On one side, there was Adolph Berle and Gardiner Means (hereinafter Berle and Means or Berle) who wrote the book "The Modern Corporation and Private Property.",32 They support the position now called "shareholder primacy", according to which a corporation exists only for the shareholders' wealth maximization, in other words, to make money for its shareholders. Berle argued that:

${ }^{30}$ Lynn A Stout, "Bad and not-so-bad Arguments for Shareholder Primacy", (2002) 75 Southern Cal L Rev 1189 at 1189.

${ }^{31}$ Sarah Bradley, "BCE Inc. v. 1976 Debentureholders: The new fiduciary duties of fair treatment, statutory compliance, and good corporate citizenship" (2010) 41:2 Ottawa L Rev 325 at 331. [Sarah Bradley, BCE Inc].

32 Adolph Berle and Gardiner Means, The Modern Corporation and Private Property (New York, Harcourt, Brace \& World, 1968). 
[A]ll powers granted to a corporation or to the management of a corporation, or to any group within the corporation, whether derived from statute or charter or both, are necessarily and at all times exercisable only for the ratable benefit of all the shareholders as their interest appears. ${ }^{33}$

Thus, Berle asserted that there is only one kind of beneficiary of a company shareholders. As such, management must act in a way to maximize shareholders' profit.

On the other side of the debate stood professor Merrick Dodd (hereinafter Dodd) of Harvard. Dodd disagreed with Berle's position regarding shareholder primacy and supported the view of a business corporation "as an economic institution which has a social service as well as a profit-making function" ${ }^{\text {34 }}$. He thought that management "should be concerned with the interests of employees, consumers and the general public, as well as of the stockholders." 35

The following discusses these two position in detail.

\subsubsection{Berle and Means on Shareholder Primacy}

In their book The Modern Corporation and Private Property, Berle and Means argued that a corporation is a means by which to earn money for shareholders. Berle demonstrated in great detail how separation of ownership and control "was increasingly

33 Adolph Berle, "Corporate Powers as Power in trust" (1931) 44 Harv L Rev 1049 at 1049.

${ }^{34}$ Merrick Dodd, "For whom are corporate managers trustees?" (1932) 45 Harv L Rev 1145 at 1148.

${ }^{35}$ Ibid at 1156. 
characteristic of the large, powerful business corporations in which the broad dispersion of share ownership necessitated delegation of responsibility for control to a small group of professional managers". ${ }^{36}$ This separation resulted in a new employee class - the managerial elite or "princes" ${ }^{37}$ - with a variety of interests, which, inevitably, lead to a conflict of interests. Shareholders seek corporate profit maximization for their own benefit, and managers seek to entrench themselves in order to use their power and facilities to suit their own interests ${ }^{38}$. In their book, Berle and Means point out as follows:

[I]t is ... evident that we are dealing not only with distinct, but often opposing groups, ownership on the one side, control on the other - a control which tends to move further and further away from ownership and ultimately to lie in the hands of the management itself, a management capable of perpetuating its own position. The concentration of economic power separate from ownership has, in fact, created economic empires, and has delivered these empires into the hands of a new form of absolutism, relegating "owners" to the position of those who supply the means whereby the new princes may exercise their power. ${ }^{39}$

Berle and Means therefore support the position whereby corporate law would offer greater protection to shareholders, paying attention mainly to problems that may arise between shareholders and directors. The authors emphasized that managers, because of their power, can easily abuse the rights of shareholders and, thus, shareholders should be protected. Berle did not pay much attention to the relationship between shareholders

${ }^{36}$ David Millon, “Theories of the corporation”, (1990) 1990 Duke LJ 201 at 220.

${ }^{37}$ Adolf Berle \& Gardiner Means, The Modern Corporation and Private Property (New York: Macmillan, 1932) at 124.

${ }^{38}$ David Millon, supra note 36 at 221.

${ }^{39}$ Adolf Berle \& Gardiner Means, supra note 37 at 124. 
because, in his opinion, they have the same interest - to increase their profit. That is why, in his view, the biggest probable threat to shareholders is management. The problem is that managers, as human beings, desire to maximize their own welfare ${ }^{40}$, contrary to the interests of shareholders. Berle pointed out: "it must be conceded, at present, that the relatively unbridled scope of corporate management has, to date, brought forward in the main seizure of power without recognition of responsibility - ambition without courage." ${ }^{41} \mathrm{He}$ emphasized that the danger was that "[w]hen the fiduciary obligation of corporate management and 'control' to stockholders is weakened or eliminated, management and 'control' become for all practical purposes absolute." ${ }^{42}$ Managerial control on issuing shares, by which they can dilute the stock influence of shareholders ${ }^{43}$, having a broad discretion over whether to distribute earnings to shareholders, and deciding whether to sell or not to sell assets of a corporation, only lends a sense of urgency to Berle and Means's analysis. ${ }^{44}$ In light of the aforementioned problems, and as a supporter of the private property model of corporate ownership, Berle added: "It requires little analysis to make plain the fact that property, as understood in the capitalist

${ }^{40}$ William Bratton \& Michael Wachter, Shareholder Primacy's Corporatist Origins: Adolf Berle and 'The Modern Corporation', online: Social Science Research Network $<$ http://www.ssrn.com>.

${ }^{41}$ Adolf Berle, "For Whom Corporate Managers are Trustees: A Note in Harvard Law Review”, (1932) 45 Harv L Rev 1365 at 1370.

${ }^{42}$ Ibid.

${ }^{43}$ Adolf Berle \& Gardiner Means, supra note 37 at 153.

${ }^{44}$ David Millon, supra note 36 at 221. 
system, is rapidly losing its original characteristics. Unless the law stops the wide open gap ${ }^{45}$ which the corporate mechanism has introduced, the entire system has to be revaluated" ${ }^{\prime 46}$. Thus, Berle's main concern was the question how shareholders could be assured that management would act to maximize their profit.

In terms of solution Berle saw the role of management as that of a shareholder trustee. The main principle of trust is to protect the interests of the beneficiary. Thus, a director, as a trustee, should act in a way to protect the interests of the beneficiary (the shareholders). Furthermore, a court has to protect the interests of the shareholder because corporate statutes define the director's power very broadly and vaguely and, in many cases, give an extremely wide leeway. "For Berle and Means, use of the trust and property analogy led necessarily to the conclusion that the trustee must act for the benefit of the equitable owner or cestui que trust - the shareholder." ${ }^{47}$ Thus, any actions of management regarding spending corporate assets, charity or other activities which are not financially beneficial to shareholders are not allowed, or can be allowed only after the shareholders' approval.

It is worth mentioning that Berle did not deny that management, as a representative of a corporation, which is a social institution, does render a social service.

45 In this case, under the notion "gap", the author means whether to act in the best interest of shareholders or to serve the society is the main duty of directors.

${ }^{46}$ Adolf Berle \& Gardiner Means, supra note 37 at 247.

${ }^{47}$ David Millon, supra note 36 at 222. 
However, in contrast to Dodd, he supported the position that when shareholders, as part of society, receive profits, they extend the welfare of the general public and by this, satisfy a social need. It is important to recognize that shareholders will spend money on, for example, extending businesses and building houses, leading to increasing job opportunities. Eventually, this reflects positively on society. The public may say a lot of negative things about businessmen; however, it is necessary to remember that they play an extremely significant role in social structure development because many of them enable society to carry on numerous beneficial activities.

Berle's shareholder primacy position, which is mostly based on "private property" rights and aggregate theory, and using the institution of trust, was not entirely new. The concept of shareholder primacy can be found in the celebrated case, Dodge v. Ford Motor Company ${ }^{48}$.

The Ford Motor Company had accumulated a capital surplus of $\$ 60$ million. The price of the Model T, Ford's mainstay product, had been successively cut over the years while the wages of the workers had dramatically increased. The company's president and majority stockholder, Henry Ford, resisted the distribution of a surplus because he planned to make massive investments in new plants that would enable Ford to dramatically increase production and the number of people employed at the plants, while continuing to cut the costs and prices of his cars. Henry Ford asserted that his ambition "is to employ still more men, to spread the benefits of this industrial system to the

\footnotetext{
${ }^{48}$ Dodge v Ford Motor Company, 204 Mich 459, 170 NW 668 (1919) [Ford case].
} 
greatest possible number, to help them build up their lives and their homes. To do this we are putting the greatest share of our profits back in the business." 49 The minority shareholders, two brothers, John Dodge and Horace Dodge, who owned $10 \%$ of the company and were the largest shareholders next to Ford, objected to his strategy, and sought to declare dividends.

The Michigan Supreme Court's response said that management should first of all be responsible to shareholders:

A business corporation is organized and carried on primarily for the profit of the stockholders. The powers of the director are to be employed for that end. The discretion is to be exercised in the choice of means to attain that end, and does not extend to a change in the end itself, to reduction of profit, or to the non-distribution of profits among stockholders in order to devote them to other purposes. ${ }^{50}$

The shareholder primacy concept, as reflected in the opinion of the court quoted above, rejects any notion of using management's power to engage in socially responsive activities $^{51}$. Instead, as Berle and Means argued, management's responsibility is to the shareholder. David Millon correctly asserts that as "trustees, managers must act only in the way that furthers shareholder financial interest, because to countenance anything else would be to allow conduct no different from outright embezzlement of shareholder

${ }^{49}$ Ford case, ibid at 468.

${ }^{50}$ Ford case, ibid at 507.

${ }^{51}$ David Millon, supra note 36 at 223. 
property by the trustee." ${ }^{52}$ In other words, it is clear that corporate activity is nothing more than the "pursuit of business objectives by individual property owners acting through fiduciaries.. ${ }^{53}$

Since the Ford case and the articulation of the view of Berle and Means, the shareholder primacy concept has become the fundamental principle of corporate law, as well as the main "guide" for managers, and the best response to corporate social responsibility arguments. Thus, if managers want to act in a manner contrary to shareholders' financial interests, they must:

- receive express authorization under the articles or bylaws;

- receive express authorization from shareholders as per resolution;

- argue that, in fact, shareholders will benefit (even if only in the long run) from this conduct.

Regarding the question of whether it is permissible to engage in charity, the court in Hutton v. West Cork Ry. emphasized that "the law does not say that there are to be no cakes and ale, but, there are to be cakes and ale except such as are required for the benefit of the company." 54

As previously mentioned, Berle did not deny corporate social responsibility. He argued that enrichment of shareholders helps to enrich society itself, because

\footnotetext{
${ }^{52} I b i d$ at 223.

${ }^{53} \mathrm{Ibid}$ at 224.

${ }^{54}$ Hutton v West Cork Ry, (1883) 23 Ch D 654 at 673.
} 
shareholders are part of society. At the end of the dialogue between Berle and Dodd, Berle wrote:

Twenty years ago, the writer had controversy with the late Professor E. Merrick Dodd, of Harvard Law School, the writer holding that corporate powers were power in trust for shareholders while Professor Dodd argued that these powers were in trust for the entire community. The argument has been settled (at least for the time being) squarely in favor of Professor Dodd's contention. ${ }^{55}$

However, as Joseph Weiner points out, this does not mean that Berle accepted Dodd's theory, but rather he agreed that social facts and judicial decisions supported that view. $^{56}$

\subsubsection{Dodd's Position: Support for Corporate Social Responsibility}

Professor Dodd of Harvard Law School held a view different from that of Berle and Means. Dodd was sure that in the wake of the Great Depression, it became clear that business apparent disregarded public welfare. While 'natural entity theory' was being used to free the corporation from government-imposed restrictions on its ability to accumulate wealth, and, as well, to imply that corporate persons owed no obligations or responsibilities different from those owed by natural persons, Dodd, in his famous article

${ }^{55}$ Adolf Berle, The $20^{\text {th }}$ Century Capitalist Revolution ( New York: Harcourt, Brace, (1954) at 169.

${ }^{56}$ Joseph Weiner, "The Berle-Dodd Dialogue on the Concept of the Corporation" (1964) 64 Colum L Rev 1458 at 1464. 
of $1932^{57}$ demonstrated how the natural entity idea could provide and support a theoretical basis for corporate social responsibility. ${ }^{58}$

According to his point of view, a manager should concern his or herself with the interest of employees, consumers and the general public, as well as stockholders. The biggest problem Dodd was faced with, was how to justify a corporate policy that is beneficial not only for shareholders, because some acts which are advantageous to employees, customers and the public may potentially put shareholders in a disadvantageous position.

His solution was based on the entity theory. He argued that if management's role is to act as a shareholder's agent, failure to promote shareholder interests over others (employees, for example) would violate managers' fiduciary responsibilities. If, however, management were the agent of a corporation itself, distinct from shareholders, and that entity was obligated to be a "good citizen", then management, acting for the benefit of a corporation, would "enjoy the power to discharge the corporation's citizenship responsibilities, even in a situation in which the shareholders might object." ${ }^{, 59}$ In other words, Dodd supported the position according to which managers are trustees for the corporation, not for its shareholders.

\footnotetext{
${ }^{57}$ Merrick Dodd, supra note 34.

${ }^{58}$ David Millon, supra note 36 at 216.

${ }^{59}$ Ibid at 217.
} 
His position was based on the core element of the entity theory - the idea that a corporation is a separate entity from shareholders. This position can be found in many cases, one of which is the famous Salomon $v$ Salomon $^{60}$. Accordingly, if a corporation is a separate entity and management works for a corporation, but not for shareholders, then management's first obligation would be to act in the best interest of the corporation, and only then, in the best interest of shareholders. Thus, in Dodd's opinion, he disproved the shareholder primacy position, which was based mainly on the aggregate theory and, consequently, on the trust relationship between management and shareholders. Theoretically, putting shareholders in the background is somehow grounded, but what about employees, customers and the general public?

Dodd's support for stakeholders other than shareholders was based on the declaration of Owen Young, the President of General Electric Co:

If there is one thing a lawyer ${ }^{61}$ is taught it is knowledge of trusteeship and the sacredness of that position. Very soon he saw rising a notion that managers were no longer attorneys for stockholders; they were becoming trustees of an institution.

If you will pardon me for being personal, it makes a great difference in my attitude toward my job as an executive officer of the General Electric Company whether I am a trustee of the institution or an attorney for the investor. If I am a trustee, who are the beneficiaries of the trust? To whom do I owe my obligations?

My conception of it is this: That there are three groups of people who have an interest in that institution. One is the group of fifty-odd thousand people who have put their capital in the company, namely, its stockholders. Another is a group of well toward one hundred thousand

${ }^{60}$ Salomon v Salomon \& Co, [1897] AC 22 HL (Eng).

${ }^{61} \mathrm{Mr}$. Young practiced law for many years before becoming a business executive. 
people who are putting their labor and their lives into the business of the company. The third group is of customers and the general public.

Customers have a right to demand that a concern so large shall not only do its business honestly and properly, but, further, that it shall meet its public obligations and perform its public duties - in a word, vast as it is, that it should be a good citizen.

Now, I conceive my trust first to be to see to it that the capital which is put into this concern is safe, honestly and wisely used, and paid a fair rate of return. Otherwise we cannot get capital. The worker will have no tools.

Second, that the people who put their labor and lives into this concern get fair wages, continuity of employment, and a recognition of their right to their jobs where they have educated themselves to highly skilled and specialized work.

Third, that the customers get a product which is as represented and that the price is such as is consistent with the obligations to the people who put their capital and labor in.

Last, that the public has a concern functioning in the public interest and performing its duties as a great and good citizen should.

I think what is right in business is influenced very largely by the growing sense of trusteeship which I have described. One no longer feels the obligation to take from labor for the benefit of capital, nor to take from the public for the benefit of both, but rather to administer wisely and fairly in the interest of all. ${ }^{62}$

In contrast to Berle, who did not trust management and, therefore, supported the position according to which management's power should be restricted since it can be used for abusing shareholders' rights, Dodd asserted that managers should be given more rights. Dodd praised Young as an example of a "real" CEO, arguing that "the only way to defend capitalism is through leadership which accepts social responsibility and meets the sound needs of the great majority of our people. Such leadership will seek to form constructive plans framed not in the interest of capital or capitalism but in the interest of

${ }^{62}$ Merrick Dodd, supra note 34 at 1154. 
American people as a whole" ${ }^{\natural 3}$. However, eventually, Dodd changed his opinion about management and in his next paper, ${ }^{64}$ started paying more attention to shareholders: "a situation in which the shareholder has to depend rather on the conscience of the management than on his own legal rights is a dangerous one" ${ }^{\prime 65}$. But, he still trusted management, and believed that they are driven by the desire for prestige rather than by pecuniary interests ${ }^{66}$.

According to the corporate social responsibility theory, the power of directors is limited by the natural entity theory. In this sense, the ultra vires doctrine first of all protects the public's interest by preventing corporate usurpations of power not specifically delegated ${ }^{67}$. This doctrine also serves shareholders to protect their interests against the use of corporate resources in unexpected and unauthorized ways. However, it had become possible to use charters with wording that gave much power to directors. Thus, they could exercise their power "for any lawful business purpose or purposes", or "to promote or conduct any legitimate objects or purposes". As well, managers could "do any and all acts, and exercise any and all powers which a natural person may do or exercise, except such as are prohibited by law to corporations." As can be seen, this

${ }^{63}$ Ibid at 1156 .

${ }^{64}$ Merrick Dodd, "Modern Corporation, Private Property and Recent Federal Legislation (1941) 54:6 Harv L Rev 917.

${ }^{65}$ Ibid at 927.

${ }^{66}$ William Bratton \& Michael Wachter, supra note 40 at 37.

${ }^{67}$ David Millon, supra note 36 at 218. 
wording vested a director with almost unlimited rights and made the ultra vires doctrine almost useless. However, the ultra vires doctrine has been used as grounds to invalidate some activities. For example, in Brinson Ry v. Exchange Bank ${ }^{68}$, a donation was adjudged as an action which was beyond the power of the President of the railway company to do.

With the foregoing summary of the two important positions on who management owes its duties to, the next part gives the author's position regarding shareholder primacy and corporate social responsibility, and shows both the positive and negative aspects of these concepts.

\subsubsection{An Argument for Shareholder Primacy over Corporate Social Responsibility}

Berle's shareholder primacy concept and Dodd's corporate responsibility theory are both well-grounded and, most important, are broadly used in many countries by academics, practitioners and judges to justify one or the other view of the corporation. But up to now, there is no concrete approach that presents a solution to the debate reflected in the Berle-Dodd controversy.

From a theoretical point of view, neither of these theories can be supported in full. Berle's shareholder primacy theory is mainly based on the property model and aggregate

${ }^{68}$ Brinson Ry v Exchange Bank, 16 Ga App 425, 85 SE 634 (1915). 
theory, which is hard to justify because in the author's view, the most common theory now is the entity model. Shareholders, de jure, do not own a corporation. A corporation is a separate entity, and it is not an aggregation of money and labor. Thus, a manager is not a shareholder's trustee, but rather a corporation's trustee. However, it does mean that this theory should be dismissed. On the contrary, the shareholder primacy position must be supported over the corporate social responsibility view.

Indeed, Dodd's corporate responsibility theory cannot fully justify corporate social responsibility by giving almost unlimited power to directors. His idea is mainly based on the entity theory, according to which a corporation is a separate entity, with its own rights and obligations. A director is a representative of a corporation and thus, first of all, has to fulfill his or her duty to the corporation, but not to the shareholders. According to this approach, it can be justified that a director should act in the best interest of a corporation. But why the director should not act in the best interest of employees, consumers and the general public is hard to justify.

Indirectly, corporate responsibility theory can be understood to satisfy the interest of the public. If a corporation makes profit, it has to pay taxes, which is in the best interest of the state and, thus, in the best interest of the public. But this position can also be accommodated by the shareholder primacy approach.

In support of his position, Dodd used the declaration of the President of General Electric Co., Owen Young. Though a respected person, arguments to support a theory cannot be based on the declarations of a public person, more so the chief executive of a corporation. Owen Young's words seem more of a public campaign to draw attention to 
General Electric. Each person likes it when someone announces that the interest of each person is the foremost task and purpose of a corporation. In 99 per cent of cases, such words are "sweet" declarations. Owen Young announced that a director should "administer wisely and fairly in the interests of all",69. It is not a secret that responsibility towards all means no responsibility at all. As the famous quote puts it: "You like every one; that is to say, you are indifferent to everyone" ${ }^{\text {"70 }}$.

We live in an imperfect world. Directors of corporations are human; thus, they are imperfect agents. They worry not only about the interests of the firms to which they owe fiduciary duties, but also about their own interests. "As a result, they may sometimes allow self-interest to prevail over duty, and shrink or even steal from the firm",71. This problem is called "agency cost" and it is a good example of shareholder primacy. Agency costs can only be reduced when someone supervises or controls a director. However, to supervise someone or something, there should be some criteria. According to the Dodd approach, there is no defining measure. Regarding this position, Professor Lynn Stout argues:

If we ask directors to consider the interests of all the firm's constituents, we are asking them to maximize the joint welfare function of happy consumers, secure employees, self-actualized managers and wealthier shareholders. How are we to tell when they are doing a good job? Although it may be simply enough, at least in theory, to determine how

${ }^{69}$ Merrick Dodd, supra note 34 at 1155.

${ }^{70}$ Oscar Wilde, The Picture of Dorian Gray (Luton: Andrews UK Limited, 2010).

${ }^{71}$ Lynn A Stout, supra note 30 at 1199. 
directors' decision affect the market price of firm's stock and even some of its bonds, measuring the value of employee security, manager selfactualization, and consumer satisfaction (to give only a few examples) is far more difficult. In contrast, it is easy to measure stock price. As a result, a shareholder primacy rule leaves directors with far less leeway to claim that they are doing a good job for the firm when, in fact, they are doing well mostly for themselves.

Professor Mark Roe of Harvard University also supports the position that shareholder wealth maximization is the best rule for corporate governance, because "a stakeholder measure of managerial accountability could leave managers so much discretion that they could easily pursue their own agenda, one that might maximize neither shareholder, employee, consumer, nor national wealth, but only their own",72. As can be seen, increasing director discretion and the number of beneficiaries can lead to negative consequences for all of them.

If a theory cannot be supported by some positions, the second means for a lawyer should be logic. Employing a logical approach in this thesis starts with analyzing Berle's theory first. Why should a director take into account shareholders? First of all, they create the company. Secondly, they invest money in the company. Thirdly, they create workplaces and hire director(s). They are liable for the company. If a company has problems, shareholders, not directors, employees, consumers and general public are responsible and directly lose money. It is very rare, if at all, that consumers or the government, in order to save a private company, had given money for free (meaning not in exchange for shares, bonds, as a loan or as a tax exemption) to a corporation which

${ }^{72}$ Mark Roe, "The Shareholder Wealth Maximization Norm and Industrial Organization” (2001) 149 U Pa L Rev 2063 at 2065. 
needs financial support. No one wants to give money without receiving something in exchange. Therefore, shareholders who transfer their own money to a company must not be expected to take care of consumers and the general public who, in turn, do not care about the shareholders. One can argue that a government takes care of shareholders by enacting statutes which protect them and give them rights. However, there is a good argument to say that this is not true. In the author's view, the government is mainly thinking about itself. It supports its own interests because business pays taxes, which is essential for the state. Thus, this situation is an example of mutual benefit. Hypothetically, mutual benefit can be present among all stakeholders. For example, when a company works well and makes profit, this goes to shareholders as dividends. For a company it is a benefit in the form of increased productivity and expansion, for instance, through buying new machines, building factories or increasing its reputation. For employees the benefit is in the form of salary increases and bonuses. For consumers, it is in the form of the company's reputation, and for the public, it is beneficial because all constituencies are "happy" and the company pays taxes. However, this scenario of benefit is a myth and it cannot be achieved because each person wants more and more benefit all the time.

According to the shareholder primacy theory from a logical point of view, a corporation can be beneficial to many constituencies. First of all, employees are a means of income for shareholders. Thus, a shareholder is concerned about employees and is interested in creating the appropriate conditions for work. But again, a shareholder does it not because he or she is generous or a good person, but rather because he or she wants to earn money, which is impossible to do without employees. It should be acknowledged 
that in capitalism, a shareholder may very well see an employee as a machine and nothing more.

The same situation applies to consumers. A shareholder is concerned about consumers only because they buy the company's products and, thus, enrich shareholders. Employees are machines that produce goods, and consumers consume them. Both of them eventually enrich shareholders and only for this reason, shareholders take care of them.

As to the general public, if a company works well, it creates jobs, workplaces and products, which are all important to the public. Most importantly, the company pays taxes, which is a form of "government salary."

In essence, this is how the system of capitalism works. In this system, most people do not really care about others, and everyone is mostly thinking about money and themselves. However, this system works because of mutual interest and because it satisfies the needs of majority people.

The foregoing structure would support the view that in a shareholder-employeeconsumer-public "food chain", the most important element is the shareholder. By analogy, the shareholder is a "sun" and employees, consumers and the public are merely planets that revolve around it. If a shareholder does not invest money in a company, all three will suffer. The general public or the state, which Dodd mostly supported, is, in this case, not a compulsory element. This is the only element without which the chain can still work.

In accordance with Berle's theory, directors should be responsible to shareholders and act in their best interest. In other words, increasing profits or market value of a 
company is the company's purpose, and consequently the directors' main obligation. Any actions which can reduce the profits of shareholders or the value of a company are intolerable.

The shareholder primacy concept also fits economic theory and is supported by it. "Market systems do both generate winners and losers." ${ }^{73}$ According to the Pareto efficiency theory, any actions, changes or transactions are efficient if at least one person is better off and no one is worse off ${ }^{74}$. In our case, if a company pays salary to employees, even if it is minimum wage, pays taxes, and also distributes dividends, the incorporation of a company is, an efficient action. In general, an efficient action will increase the wealth of society ${ }^{75}$, which is the main aim and principle of economics. This principle does not constantly work in Dodd's approach. For example, according to his position, it is impossible to justify lottery or casino activities. If a director shall act in the interests of consumers it means that if a consumer loses money in a lottery (which is extremely likely), a director is not carrying out of his/her duties in an appropriate way.

73 Michael Treblicock, "Economic Analysis of Law" in Richard Devlin ed, Canadian Perspectives on Legal Theory (Toronto: Emond-Montgomery Publishing Ltd, 1991 at 83.

${ }^{74}$ Richard A Posner, "The Ethical and Political Basis of the Efficiency Norm in Common Law Adjudication" (1980) 8 Hofstra L R 487 at 488. See also Richard A. Posner, The Economics of Justice (Cambridge, Massachusetts and London, England: Harvard University Press, 1981).

${ }^{75}$ Richard A Posner, "The Ethical and Political Basis of the Efficiency Norm in Common Law Adjudication”, supra note 74 at 505. 
According to Dodd's model, a corporation is an economic institution which has social service as well as profit-making functions. Socially, it seeks to balance the interests of the employees, consumers, the general public and shareholders. In his view, a director should act in the best interests of all the constituencies of a corporation and the general public. Apple Inc., the most valuable (by market value) corporation in 2011, can serve as an example. In 2011, Apple's net profit was 25,922 billion dollars, and the corporation employed more than 60,000 people. This is a big corporation with many employees, consumers, and shareholders and it is very influential in the world. According to the shareholder primacy concept, Apple's directors have to carry out one of the following three actions ${ }^{76}$ :

- declare all profits as dividends for shareholders;

- not declare dividends and, instead, keep this money in the company account or spend it on development;

- declare dividends and keep some money in the company account, or spend it on development.

Generally, this is the full list of directors' actions according to Berle's approach regarding the distribution of profits. On the contrary, according to Dodd's theory, Apple's directors have to fulfill one of the following actions:

- declare all profits as dividends for shareholders;

${ }^{76}$ This example is concerned only with distribution of profits. 
- not declare dividends and, instead, keep the money in the company account, or spend it on development;

- declare dividends and keep some money in the company account, or spend it on development;

- spend all or part of the profit on employee salary or bonuses;

- hire more employees;

- $\quad$ spend all or part of the profit as donations to the "public ${ }^{77 " \text {; }}$

- $\quad$ spend all or part of the profit as gift to consumers ${ }^{78}$;

- take any combination of the aforementioned actions.

Clearly, Dodd's directors have much more leeway that Berle's. They have more rights, and more possibilities and temptations to abuse them, but Dodd's directors have to act in everyone's best interest. From a logical point view, "in everyone's best interest" means that everyone's interest should be "equally" taken into account. This is because if someone receives more than the other, it means that a director is not acting in the best interest of someone who received less. Therefore, Apple's directors have to divide all the profit into 4 or $3^{79}$ parts. They must give one part to the shareholders. If this happens, on the same day, the shareholders will try to sell shares and reinvest in other countries (if the same policy works in the whole country). They must give another part to employees in

${ }^{77}$ The public here means the government.

${ }^{78}$ In practice, this means that from the next year Apple Inc can sell its products, for example, at a 70 per cent discount, and compensate losses from the profit.

${ }^{79}$ We may not have to count the government, because a company has already paid taxes and it would be unfair to include the government in this. 
the form of bonuses or salaries. Employees will be very happy and will "pray" for the company's welfare. Then, they must give another part to consumers, or minimize product prices and increase product quality. Eventually, the fourth part would go to the government. As can been seen, under ideal conditions, shareholders are treated unequally. They bear the biggest risks, but at the end receive the same interest as others, who do not risk anything at all or risk less than the shareholders. Thus, we can see that under ideal conditions, shareholders are unsatisfied. But if one constituency is not satisfied, and everyone is part of society, it can be said that society itself is unsatisfied. Thus, logically, Dodd's approach is senseless. A manager cannot act in the best interest of all constituencies in a company.

Reverting to Apple Inc, it can be asserted that because it is one of the most influential companies in the world, it should be socially responsible. This would be Dodd's view. In 2011, the company faced a large scandal. Its employees in China earned almost nothing, compared to its employees in other countries. An Apple employee in China earned 4 times less than an Apple employee in Korea ${ }^{80}$. Moreover, employees in China repeatedly filed complaints about miserable working conditions in Apple factories. In this case the directors did not act in the best interests of the employees. But the government could do nothing because Apple is an important company for society and country. As well, the directors can at any time declare that they paid the employees

\footnotetext{
${ }^{80}$ Tim Worstall, Chinese Workers Get Only \$8 From Each Apple iPad 2, online: Forbes <http://www.forbes.com>. See also Rob Cooper, Inside Apple's Chinese 'sweatshop' factory where workers are paid just $£ 1.12$ per hour to produce iPhones and iPads for the West, online: Mail Online <http://www.dailymail.co.uk>.
} 
minimum wages and, therefore, they were not in breach of the law. The situation with government was not any better. Apple Inc.'s effective federal income tax rate in the US was less than 10 percent (instead of 35), "depriving U.S. government coffers of an estimated \$2 billion+ and the State of California a hefty amount as well". ${ }^{81}$ Again, Apple's directors did not act in the best interest of the general public, but again, there was no punishment. This can be understood from a legal point of view. They used many jurisdictions to optimize taxation, which is completely legal. However, if one only uses the "letter of the law", one cannot find any instruction according to which a director has to act in the best interests of the general public and consumers. They do not have any direct relationship with the corporation.

In general, the corporate social responsibility approach looks more like a "sweet utopia" or a "desire" (because it is impossible to act in everyone's best interest in a capitalistic world) rather than reality. But this theory is a good instrument to support some unpopular action that is detrimental to shareholders. It can also serve to protect directors from responsibility, or to balance shareholder primacy against director discretion. Written during the Great Depression, this theory was mainly indented to overcome that crisis. For the crisis time, some restrictions, a limitation of rights, and the distribution of welfare from some people, in order to support others, are permissible. However, it is necessary to point out the fact that it is permissible not because of corporate law, but rather because of the extraordinary nature of the situation. Dodd was

${ }^{81}$ Peter Himler, Apple Taxes and PR, online: Forbes <http://www.forbes.com>. 
sure that management would become civil servants and would manage in a good way to gain prestige:

Such service has in most civilized communities, from the age of Pericles to the age of Mussolini and Stalin, conferred upon the higher ranks of public servants power and prestige unequalled by that given to any other class in the community [...] If, as has not infrequently been the case in the history of western civilization, man have been educated to regard power and prestige of public office as more important than material riches. ${ }^{82}$

Nowadays it is quite rare to meet an honest person. Very often today, prestige is measured in terms of money. Today, we use the word "prestige" as an indicator of financial success. Someone might have a prestigious car, live in prestigious area, or work at a prestigious (well-paying) job, which again are all measured in terms of money. Nowadays, almost no one can say that teaching in a school (not in a university) is a prestigious job. Some time ago, however, it was extremely prestigious to be a teacher in a school. Again, today, people trust each other less. Some time ago, the words of an honorable person would be put in evidence in a court. Now, this is not the case. This is not to say that the past was better than the present; rather, it is to emphasize that a lot of things have changed, especially attitudes towards the system of values. Thus, to assert that a manager will perform his duties in a fair way because of prestige has little relevance today, if any at all.

82 Dodd, "Is Effective Enforcement of the Fiduciary Duties of Corporate Managers Practicable?” (1935) 2 U Chi L Rev 194 at 203. 
When someone takes into account first the interests of society and then his or her own interest, this can lead to extremely negative consequences ${ }^{83}$. Some of the people that Dodd used as examples of the "right" managers ${ }^{84}$ who would protect the rights and interests of employees, customers, the general public and shareholders discredited themselves and cannot be believed or given unlimited power today.

As earlier argued, in general, Dodd's approach seems impractical. It comes across more like a slogan or ideology than a theory based on law and doctrine. However, it can be used beneficially in some cases and, furthermore, can be used appropriately. Today, many corporations are more than just corporations, but not from a corporate law point of view. These include oil companies which build new cities where the only jobs are provided by them; banks, which have trillions of dollars worth of assets; investment trusts, which manage substantial funds; and television broadcasting companies, which spread news to billions of people. All of these companies should not be controlled in the same way as other corporations (again, not because of corporate law, but because of their significance). A private bank is not just a private corporation; it is part of the country's banking system and, indeed, the whole monetary system depends on the banks. Losing a bank could lead to a chain reaction that could eventually destroy the monetary system to everyone's detriment. Managers of a bank have to act not only in the interests of shareholders, but also predict risks that the general public may face. The same situation would prevail if a corporation is a monopoly. A monopolistic company cannot regulate

\footnotetext{
${ }^{83}$ These types of mindsets are typical to communism or socialism.

${ }^{84}$ Joseph Stalin, Benito Mussolini.
} 
prices by itself, and use an "open pricing mechanism", which other companies can do. But, these big and influential companies are the exceptions rather than the general rule.

Many who advocate increasing directors' rights and powers support their position by giving examples that center on "anti-takeover" statutes and several key decisions, such as Unocal Corporation v. Mesa Petroleum Co. ${ }^{85}$, Revlon, Inc v. MacAndrews \& Forbes Holding Inc. ${ }^{86}, B C E$ v 1976 Debentureholders ${ }^{87}$. Those who do not advocate this position base their examples on "not-anti-takeover statutes" 88 and related cases which openly express the position that directors have to act in the best interest of shareholders ${ }^{89}$.

It is not a secret that takeover is not the whole of corporate law; this is only a small part of it. Moreover, in closely-held corporations, takeovers are almost nothing. This confirms the position according to which a director's power in a "takeover" action is unusual, more like an exception than the main rule. "Anti-takeover" statutes are questionable and are criticized as ineffective or counterproductive for the advancement of non-shareholder interests. As Ruth Kuras systemizes:

${ }^{85}$ Unocal Corporation v Mesa Petroleum Co, 493 A (2d) 946 (Del Sup Ct 1985).

${ }^{86}$ Revlon, Inc v MacAndrews \& Forbes Holding, 506 A (2d) 173 (Del Sup Ct 1986).

${ }^{87} B C E v 1976$ Debentureholders, 2008 SCC 69, [2008] 3 SCR $560[B C E]$.

${ }^{88} \mathrm{~A}$ non-anti-takeover statute unlike an anti-takeover statute, usually explicitly stipulates that a director has the duty to sell shares for the highest price.

${ }^{89}$ For example, Ford Case, supra note 48. 
First, the permissive nature of the permissive statutes means that the consideration of stakeholder interests is discretionary. Consequently directors can easily ignore their interests. Second, these statutes are not enforceable. There is no remedy for a failure to consider stakeholder interests. Third, the term "stakeholder" is not clearly defined. General terms such as "customers" or "community" are ambiguous and there is no guidance to define them. Fourth, these statutes may be abused by boards seeking to entrench themselves. Directors may hide behind vague duties to conflicting groups to serve their own interests; too much discretion is conferred without assigning any corresponding responsibility. Almost any corporate action can be justified as in the interest of some constituency. Fifth, the legislation does not explain why directors should have responsibilities to various constituencies, nor does it provide standards for assigning relative weights to the constituents. ${ }^{90}$

It is hard not to agree with these observations. In fact, though the idea of corporate social responsibility makes sense, it does not belong within corporate law. Some common place examples would illustrate this point: normally, no one would want his or her money in his or her own private bank account to be used for someone else. As well, no one would want another to come to their home and start living in it without permission, simply because he or she does not have a place to live. Similarly, no one would want to be called by the director of his or her company to be told that the director gave the company's machines to the government but hired hundreds of employees. All of this would start with the declaration of social responsibility, which would be followed by the cancellation of private property because private property causes a stratification of people and does not satisfy everyone's needs equally.

90 Ruth Kuras, "Corporate Social Responsibility: A Canada-US Comparative Analysis" (2002) 28 Man LJ 303 at 310. 
Those who support the corporate social responsibility policy depart from the essence and substance of corporate law. This goes back to the days when the Roman Empire jurist Ulpian divided law into public and private. Back then many lawyers, mainly from civil law countries, developed this division. ${ }^{91}$

In short, the difference between public and private law designates whose interest the law serves, and who initiates the protection of those interests. For example, criminal law is a public law because it serves the interests of the state. Indeed, it is government that starts the process of prosecution when someone breaches a rule of criminal law. There is no legal equality of parties and leeway in public law. If someone commits a crime, a police officer must open a criminal case. If a court awards a fine in a criminal case, it must be paid not to the victim, but to the government. Civil law, on the contrary, is private law. All parties are equal. If one wants to sign a contract with an organization, one can choose to sign it or not sign it. No one, as a general rule, can compel anyone to sign a contact or to sell assets in civil law against their free will. If someone breaches a contract, the other party, not the government, decides whether to start a lawsuit or not. In civil court, parties have equal rights. Finally, if a court awards a fine in civil case, it must be paid to the injured party, but not the government.

Thus, supporters of corporate social responsibility deviate from the tenets of private property and, in the author's view, forget that corporate law is private law.

${ }^{91}$ See for example, Rudolf von Jhering \& John Lalor, The Struggle for Law (Chicago: Callaghan and Company, 1915). 
Corporate law has to serve private interests, not public interests. Businessmen have one main interest, to make money. Corporate law regulates the formation and functioning of corporations. Functioning, in this case, is the system of rules that regulate relationships within a corporation and with other contracting parties. A company is created with the objective to make profit, if other objectives are not specified in the articles of association. Their objectives are different from those of charities, schools, universities and so forth. A company consists of shareholders and employees ${ }^{92}$. Thus, the relationships which can possibly arise in a company are those between the corporation and a shareholder; between a shareholder and another shareholder; between the corporation and an employee; and between an employee and another employee. It is also possible for there to be a relationship between a director and a company, if the director is not an employee. A relationship between an employee and an employee, and a relationship between a corporation and an employee, are both regulated, mainly, by labor law. Therefore, there remain only the corporation-shareholder, shareholder-shareholder and directorcorporation relationships. A director is a corporation's agent or representative. Thus, we have the following relationships: director-shareholder, shareholder-shareholder, directorcorporation. We cannot substitute the last relationship because articles of associations specify the relationship between a director and a corporation. We can, however, substitute a director-corporation relationship with a director-shareholder relationship because shareholders define a director's rights and obligations in the articles. Thus, we come to the conclusion that internal corporate relationships, that is, relationships within

${ }^{92}$ Can also be a director, if he/she is not an employee. 
the corporation, are relationships between a corporation and the shareholder, a shareholder and another shareholder, and, with much difficulty, between a corporation and a director. This internal relationship and the external ones generated with other contracting parties should be the subject of corporate law. Internally, the relationships can simply be defined as between shareholders and directors. All shareholders pursue profit. Thus, the director should act in the best interest of the corporation, which means, in the best interest of the shareholders, not the employees, consumers, the environment or the general public. Social responsibility should be a general principle or idea for social behavior, probably an ideology, but not a rule of corporate law.

The government must care about employees, consumers, the environment and the general public, by enacting better statutes for employees to increase minimum wages, reduce working hours and improve working conditions, all as matters of administrative and labor law. It is also a government's duty to establish better standards for the quality of products and consumer services which is also administrative law. It must also toughen standards regarding environmental policy towards improvement of environment, which is again the task for administrative or environmental law, but not corporate law. Corporate law cannot and does not have to solve these problems. Private corporations do not ask governments to delegate authority to them so they could perform the functions of a court or a parliament, because these are not their obligations. Similarly, a government should not ask corporations to perform governmental functions. 


\subsubsection{Conclusion}

Nowadays, it is impossible to disprove both the shareholder primacy theory and the corporate social responsibility theory. The use of the theories varies from firm to firm, from time to time, and from case to case. However, it is possible to prioritize them. Shareholder primacy should be the main principle by which the management of a corporation carries out its duties, because this principle clearly defines directors' duties. Corporate social responsibility theory is very vague and gives too much power to a director, but does not show how that power can be channeled. There are a minimum of four constituencies to be satisfied by a corporation; choosing to satisfy one of them means moving away from the other three. In essence, corporate social responsibility does not have one measure of evaluation regarding a director's performance. The preferred option, however, is to have one main criteria by which to assess director performance. Shareholder primacy answers the question as to who is the beneficiary of a corporation, and whose interests the directors must protect.

Now that the fundamental issues regarding relations between majority and minority shareholders, and shareholders and directors, have been discussed, it is necessary to focus on the shareholder's rights and the ways to protect them. The next Chapter analyzes these issues. 


\section{Chapter III}

\section{SHAREHOLDER PROTECTION IN CIVIL LAW COUNTRIES: \\ UKRAINIAN AND GERMAN EXAMPLES}

\subsection{Introduction}

Some analysts support the position that common law countries protect their shareholders better than civil law jurisdictions do. According to La Porta's rankings, ${ }^{93}$ analysts came to the conclusion that "the quality of shareholder protection varies across different jurisdictions depending on which legal family system the jurisdiction belongs to. ${ }^{\prime 94}$ As well, the yearly World Bank ranking of countries regarding doing business ${ }^{95}$ has 10 indexes by which every country is assessed: starting a business; dealing with construction permits; getting electricity; registering property; getting credits; protecting investors; paying taxes; trading across borders; enforcing contracts; and resolving insolvency.

The World Bank identifies the protection of investors as an index, to help prospective investors choose the "correct (right) jurisdiction" for investment. This ranking measures the strength of minority shareholder protections against directors' misuse of corporate assets for personal gain. The indicators distinguish 3 dimensions of

${ }^{93}$ La Porta, supra note 4.

${ }^{94}$ Udo C Braendle, supra note 5 at 257.

95 Doing business, supra note 6. 
investor protections: transparency of related-party transactions, liability for self-dealing and shareholders' ability to sue officers and directors for misconduct. The data for this ranking come from a survey of corporate and securities lawyers and are based on securities regulations, company laws, civil procedure codes and court rules of evidence. ${ }^{96}$ This ranking indicates that civil law countries are far behind the common law ones. Canada is fifth in the world, and Germany and Ukraine are $97^{\text {th }}$ and $111^{\text {th }}$ respectively. Thus, taking Canada as an example of a well-protected shareholder jurisdiction is reasonable. Ukraine can and must borrow some practices from Canada on how to protect majority and minority shareholders alike.

This analysis of the civil law system of shareholder protection will be unfair and incorrect if Canada is compared only with Ukraine. Thus, this chapter examines shareholder protection based on German law as well. Ukraine is an immature country which has been developing shareholder protection for only several decades. On the other hand, Germany ${ }^{97}$ has been developing its civil and commercial laws for several hundred years. Ukraine pursued communism, which did not have the free-market system essential to commerce, while Germany has long had a fully formed market system. Ukraine is one of the least developed countries in Europe, whereas Germany is one of the most developed, not only in Europe, but also in the world. Finally, most Ukrainian law schools

\footnotetext{
${ }^{96}$ Doing business, supra note 6.

${ }^{97}$ In this case Germany means the Western part of Germany.
} 
teach German civil and commercial law as the best example to emulate. Thus, Germany is very well suited as an additional country to compare with Canada.

This Chapter analyzes minority shareholder protection in civil law countries based on Ukrainian and German laws. It starts with general information on private companies and the laws which regulate corporate relations in the two countries. Then, it examines voting and related rights, right to information, withdrawal from a company, expulsion, dissolution of a company, derivative action (suit) and direct action, in Ukraine and Germany. The Chapter pays attention to the difference between stakes and shares in closely-held companies in this analysis. Finally, it discusses problems of protection in the civil law system that cannot be favorably resolved for minority shareholders.

\subsection{Private Companies in Ukraine and Germany: General information}

Before analyzing shareholder protection in Ukraine and Germany, it is necessary to give a short introduction of Ukraine and Germany and their corporate law. Ukraine is a relatively new state. It became independent from the USSR in 1991. Before independence, there were no private properties and, correspondingly, it was not possible for people to open companies. All companies were owned and controlled only by the government. As such, no one really examined private law, including corporate law. Furthermore, if someone wrote about the advantages of private property or privately owned corporations, as opposed to supporting the position that communism was "the best thing ever invented 
by human", this person would automatically be inspected by the police or KGB and likely put in prison for the calling for overthrow of the social order.

Thus, following the disintegration of the USSR, Ukraine simply did not have a good modern legal system - one that could apply to new demands such as private property rights and their protection, formation of companies, privatization, and so on. To improve the situation, especially regarding civil law, of which corporate law is a part, Ukrainian scholars started studying the knowledge and experience of other countries in order to adapt their legal system to what they learned from those countries. Ukrainians, like Russians, focused mainly on two branches of the civil law system - French and German. It is not the task of this thesis to analyze why, but eventually, Ukraine relied upon the German example.

Like Germany, Ukraine has Civil and Commercial codes, which were built on the "pandect" basis. This means that there is the General Part, which can be used for all of a code's books (chapters), and the Special Part, used for special relationships, such as different types of contracts. In contrast to the "pandect" system, the "institutional system" does not have the General Part. However, each book (chapter) has general and special provisions. This construction of the code is typical to French law.

The most important normative (regulatory) instruments that govern Ukraine's corporate relationships are the following statutes: 
- Civil Code of Ukraine ${ }^{98}$

- Commercial Code of Ukraine ${ }^{99}$

- Civil Procedural Code of Ukraine ${ }^{100}$

- Commercial Procedural Code of Ukraine ${ }^{101}$

- Law “On Business Associations"102

- Law "On Joint Stock Companies of Ukraine"103

The most important statutes that regulate Germany's corporate relationships consist of mainly the following statutes.

- Civil Code of Germany or Burgerliches Gezetzbuch (BGB) ${ }^{104}$

98 Civil Code of Ukraine, 16.01.2003 № 435-IV, Official website of the Verkhovna Rada of Ukraine (Parliament) <http://www.rada.gov.ua> [translated by author].

${ }^{99}$ Commercial Code of Ukraine, 16.01.2003 № 436-IV, online: Official website of the Verkhovna Rada of Ukraine (Parliament) $<\mathrm{http}$ ://www.rada.gov.ua $>$ [translated by author].

${ }^{100}$ Civil Procedural Code of Ukraine, 18.03.2004 № 1618-IV, online: Official website of the Verkhovna Rada of Ukraine (Parliament) <http://www.rada.gov.ua $>$ [translated by author].

${ }^{101}$ Commercial Procedural Code of Ukraine, 06.11.1991 № 1798-XII, online: Official website of the Verkhovna Rada of Ukraine (Parliament) $<$ http://www.rada.gov.ua $>$ [translated by author].

${ }^{102}$ Law “On Business Associations”, 19.09.1991 № 1576-XII, online: Official website of the Verkhovna Rada of Ukraine (Parliament) <http://www.rada.gov.ua $>$ [translated by author].

${ }^{103}$ Law "On Joint Stock Companies of Ukraine”, 17.09.2008 № 514-VI, online: Official website of the Verkhovna Rada of Ukraine (Parliament) $<$ http://www.rada.gov.ua $>$ [translated by author]. 
- Commercial Code of Germany or Handelsgezetzbuch (HGB) ${ }^{105}$

- The German Act relating to Public Companies (Aktiengezetz) ${ }^{106}$

- The German Private Companies Act or Gesetz betreffend die Gesellschaftcn mit beschrankter Haftung. ${ }^{107}$

In connection with the corporate law of Ukraine and Germany, it must be noted at the outset that "two separate corporation statutes, each representing the basis for the formation and operation of a different corporation entity, exist side by side in one jurisdiction" ${ }^{108}$. These two statutes consist of the Ukrainian Law "On Business Associations" and The German Private Companies Act, which provide the legal basis for the formation and operation of private limited liability companies, and the Ukrainian Law "On Joint Stock Company of Ukraine" and "The German Act Relating to Public Companies", which govern the formation and operation of public liability companies. In addition to the above-mentioned statues, which regulate different kinds of companies,

104 German Civil Code (Bürgerliches Gesetzbuch), online: German Federal Ministry of Justice $<$ http://www.gesetze-im-internet.de/englisch_bgb $>$.

105 German Commercial Code (Handelsgezetzbuch), online: German Federal Ministry of Justice $<\mathrm{http}: / /$ www.gesetze-im-internet.de $>$.

${ }^{106}$ The German Act relating to Public Companies (Aktiengezetz), online: German Federal Ministry of Justice $<$ http://www.gesetze-im-internet.de $>$.

${ }^{107}$ The Private Limited Companies Act (Gesetz betreffend die Gesellschaftcn mit beschrankter Haftung), online: German Federal Ministry of Justice $<$ http://www.archive.org/stream/germancommercial00germuoft/germancommercial00ger muoft_djvu.txt>.

${ }^{108}$ Enno W Erchlentz, Modern German Corporation Law: Volume I (New York: Oceana Publications Inc, 1979) at xv. 
both of these jurisdictions must comply with the prescriptions of Civil and Commercial codes.

In Ukrainian legislation, a Limited Liability Company (hereinafter LLC), is, according to Article 50 of the Law "On Business Associations", a company that has authorized capital which is divided into stakes (not shares), the size of which is stipulated by the articles of incorporation. ${ }^{109}$

A Limited Liability Company is the prevailing form of business association in Ukraine and Germany. Some major reasons for the popularity of this kind of legal entity are the following:

- It has a simple and relatively cheap procedure of incorporation. For example, there is no capital requirement for the LLC in Ukraine, which means that one hrn. ${ }^{110}$ will be enough to fulfill the requirements for its authorized capital. For instance, an authorized capital of a Joint Stock Company in Ukraine constitutes 1250 minimum salaries, roughly $\$ 155000$ Canadian Dollars. A similar situation obtains in Germany, where there is the possibility of opening a company with an authorized capital of one Euro ("mini”-GmbH). However, the $\mathrm{GmbH}$ requires a minimum 25000 euro as authorized capital, compared to German Joint Stock Company, which requires 50000 euro.

\footnotetext{
${ }^{109}$ Law “On Business Associations", supra note 102, Article 50.

${ }^{110}$ Ukrainian currency - Hrivna.
} 
- Shareholders have a wide discretion regarding the formation of its governance structures.

- It has limited liability, a crucial factor for the shareholders.

Compared to Canada, a Ukrainian LLC does not have shares at all. Instead of shares, which are a form of security, it has stakes. This feature gives rise to more disadvantages than advantages. The only advantage of having a stake instead of a share is that the incorporator does not have to pay a fee for keeping the shares in the "security keeper", and does not have to open a special account with the registrar. In other words, it is less costly. However, because of this feature, many problems arise with succession, transferring, and so on. These problems will be analyzed in more detail below.

An LLC has a wide discretion to form governance bodies. However, there is usually a two-tier governance structure, very similar to the Canadian system. The higher body is a general meeting of shareholders. The executive body is a director or board of directors. There is no obligation to form a supervisory board.

Existing Ukrainian legislation does not pay attention to the duties of a director. For this reason, it is useful to consider the Canadian director's obligations, which are stipulated in $\mathrm{s} .122$ of the $\mathrm{CBCA}^{111}$. Incorporating this article into Ukrainian legislation or in a by-law (articles of association), would not contradict Ukrainian law. Indeed, providing ahead for a director's obligations would lead to better protection for

${ }^{111} C B C A$, supra note 8 at s 122. 
shareholders. In Ukraine only a natural person, and not a legal entity, can be a director. A director can work on the basis of labor contracts or civil contracts.

Pursuant to s.4 Article 23 of the Law "On Business Association”, and s.4 Article 89 of the Commercial Code of Ukraine, the company's officers are responsible for any damage they cause to the company, in scope and degree, as stipulated by laws (statutes) and articles of association. Since the status of a director of the LLC can be different, corresponding conditions and degrees of responsibility can also vary. Because of this the legal rules regulating the liability of officers to the company are also different.

Where the relationship between an officer and a company arises on the basis of a labor contract, the officer's responsibility for direct damage is stipulated by the norms of Chapter IX of the Labor Code of Ukraine ${ }^{112}$. In this case, several conditions must obtain for the officer to bear responsibility: breaching labor obligations by the officer; the existence of direct damage; a cause-and-effect relation between breaching of obligations and damage; and the guilt of the officer. The absence of even one condition forecloses the possibility of holding the officer financially responsible.

In the case that a relationship is derived from civil contract (that is, when an officer is not an employee of the company), his liability for damage is determined by rules stipulated in the Civil Code of Ukraine. In this case, damage means the following:

${ }^{112}$ Labor Code of Ukraine, 10.12.1971 № 322-VIII, online: Official website of the Verkhovna Rada of Ukraine (Parliament) <http://www.rada.gov.ua $>$ [translated by author]. 
- losses incurred by a person as a result of destroying or damaging something, as well as expenses which a person has incurred or must incur in order to restore violated rights (real losses);

- the loss of income a person could receive under ordinary circumstances if his/her/its right had not been violated (lost profit). ${ }^{113}$

For indemnification of any losses derived from the civil contract, the general rules for indemnification are used. It is important to note that the Civil Code of Ukraine does not stipulate guilt as a compulsory element for responsibility for damage caused by an officer: "The person that violated the obligation shall be responsible, provided his guilt (intent or negligence) is obvious, unless otherwise stipulated by the agreement or the law"114. Thus, it is possible to have a provision in the agreement according to which an officer bears liability even in the case that he or she is not guilty. However, in Ukraine the liability of officers are limited to indemnification for direct damage. It is worth noting that it is extremely rare that an officer actually indemnifies for the damage. As Roman Sabodosh notes, "we do not know any examples when a member of the executive body of the company has indemnified damage caused by the actions of a member of the executive body of the company. However, we have to start forming such a practice in order to avoid the abuse of the power by the executive members $" 115$.

${ }^{113}$ Civil Code of Ukraine, supra note 98, Article 22.

${ }^{114}$ Ibid, Article 614, see also Article 906.

115 Roman Sabodosh, Lection III, Corporate Management in Joint Stock Company" (Part 3: The Executive Organ) (2010) [unpublished, archived at Kyiv 
There are several causes of this. First, usually an interested person does not have a right to bring a lawsuit because of the absence of a breached right. The lawsuit can be brought by CEOs, shareholders, or some other person who is vested with this right in a by-law. However, to bring any lawsuit in Ukraine, a complainant has to show that his/her right has been breached. In other words, for example, a shareholder has to provide information that includes the way that the right has been breached. Thus, a court usually declines a lawsuit with the explanation that "the court did not find any evidence which indicates that any rights of a complainant were breached". Second, in almost every case, a director is working under a labor contract. According to the Labor Code of Ukraine an employee bears a financial liability to the limits of direct losses, but this liability cannot exceed the employee's average monthly earnings ${ }^{116}$. There are, of course, some exceptions, but if a contract does not specify full indemnification, an employee will be responsible to the limit of one salary. This is why it is not worth bringing a lawsuit to recover losses, as a company will pay more money in lawyer and judicial fees, and so on, than it may recover in the suit.

According to Article 58 (5) of the Law "On Business Associations", a general meeting is required to elect the "Head of the Company". However, statutes, by-laws, or recommendations do not provide any explanation as to who the "head of the company" is, and what his obligations are. Only one provision can be found regarding the head of the

National University named after Taras Shevchenko, Faculty of Law [translated by author]].

${ }^{116}$ Labor Code of Ukraine, supra note 112, Article132. 
company, which is Article 23 (2) of the above mentioned statute. This only says that he has the right to call the general meeting, chair it, and keep the minutes of the general meeting. This means that the by-laws or articles of association are used as the only source of law in this case. But a "head of a company" and its CEO should not be conflated. In Ukraine, these are two different persons representing the different bodies of power in a corporation. The CEO is the head of the executive body, while the head of a company is, generally speaking, much harder to identify. In Ukraine the majority of people do not even hear about who the head of a company is, and the majority of those who do hear generally think that the head of the company is the head of the executive body, in other words the CEO. This is not the case, though the legislators may, in reality, be referring to the CEO. The situation when a legislator uses words without any explanation is common in Ukraine. Moreover, one form of legal entity, a Business Enterprise ${ }^{117}$, is covered by only one provision. Even so, Business Enterprises are the second-most common form of legal entity in Ukraine.

From another perspective, however, identification of the head of the company is not a problem at all. There are two possible solutions to this problem. The first is not to elect the head of the company. According to law, a general meeting shall elect the head of the company, but no one can force a general meeting to elect someone. Moreover, there is

${ }^{117}$ According to Commercial code of Ukraine Article 113, Private Enterprise is an enterprise (a form of company) which operates on the basis of private property of one or more persons and with use of his or their labor, or use of a labor force. This is the only provision regarding Ukrainian Private Enterprise. The law is silent about authorized capital requirements, about compulsory governance structure and so on. Everything should be in the by-law (articles of association). 
no sanction if the corporation does not elect such a person. This is an example in which the law is not working properly because of the absence of sanctions. A second way around the situation is to vest the rights in the head of the company as the supervisory board in a Joint Stock Company, and as a rule delegate the control functions of a general meeting to represent its interests between general meetings. The second option is better, because it fully fulfills relevant legal requirements and provides a "watch-dog" for the shareholders.

German law does not have problems with differentiating the corporate governance structure because the legislation explicitly defines the corporation's possible organs and moreover, stipulates their duties. According to German law a private company usually consists of a general meeting and board of directors (or director). ${ }^{118}$ It is not compulsory to form a supervisory board in this type of company.

For controlling a board of directors (or director), a general meeting could form an auditing committee and/or invite professional auditors who do not have any material interest in the company or any association with its shareholders. The powers of an auditing committee must be prescribed to foresee problems that may affect the shareholders. The auditing committee and the auditors must report directly to shareholders at a general meeting. Members of the board of directors (executive body) and the head of the company cannot be members of an auditing committee. A very

${ }^{118}$ German Civil Code, supra note 104, Paragraph 26. 
important consideration is that, without the resolution of a control body, a general meeting cannot approve annual reports and balance sheets.

\subsection{Protecting Minority Shareholders in Ukraine and Germany}

This section examines minority shareholder protection under Ukrainian and German law. The articles of association play a vital role in operating a corporation. However, the articles vary from company to company. Thus, in this section, the discussion of minority shareholder protection is mainly based on statutory provisions. The discussion highlights the problems existing in Ukrainian and German corporate law, but does not offer solutions to them. Further sections suggest possible ways of solving problems.

As mentioned, minority shareholders can be oppressed by the majority as well as by management. Therefore, it is necessary to examine minority shareholder protection in two contexts. The first is in terms of the relationship between the majority and minority shareholders, and the second involves the relationship between management and minority shareholders.

Corporate law theory has many remedies for minority shareholder oppression, such as voting rights (cumulative voting, class voting and voting rights under squeezeout), derivative action, oppression remedy, right to dissent, compliance or restraining 
order, investigation, dissolution, right to examine a company's documentation, cancellation of contracts, cancellation of general meeting decisions and other remedies.

Professor Sarah Bradley rightly mentions in her Commentary on the Nova Scotia Companies Act, that the right to vote at meetings is a fundamental right granted to shareholders ${ }^{119}$. Thus, this section starts by examining voting rights.

\subsubsection{Voting and Related Rights}

The voting right is the fundamental and most important right belonging to shareholders. This right is exercised by shareholders in general meetings. A general meeting is considered the highest (supreme) body ${ }^{120}$ within the corporation. In Ukraine, the decision of a general meeting binds for all of a company's members.

A Ukrainian LLC does not have shares; instead it has stakes. Thus, in the general meeting, one stake comes with one vote. This formula works in every Ukrainian LLC and cannot be changed. There are no ordinary, preference or class stakes. Each stake is equal and carries the same rights. Everyone who has a stake in a company is counted as a member of the company. According to Article 50 of the Law "On Business Associations" ${ }^{\prime 121}$ a company shall not have more than 100 members. In the event that

119 Sarah Bradley, Nova Scotia Companies Act \& Commentary (Markham, Ontario: LexisNexis Canada, 2012) at 48.

${ }^{120}$ Law "On Business Associations", supra note 102 at Article 58.

${ }^{121}$ Ibid, Article 50. 
membership exceeds this number, a limited liability company shall be subject to transformation into a Joint Stock company within one year and, upon the expiration of this term, to liquidation by prosecution if the number of its members does not decrease to the established limit. ${ }^{122}$

According to Article 145 of the Civil Code, the exclusive competence of the general meeting of a limited liability company includes the following:

1) determining the main directions of activities of the limited liability company and approving its plans and reports on their fulfillment;

2) amending the company's articles and changing the amount of authorized capital;

3) forming and recalling the company's executive body;

4) establishing forms of supervision over the activities of the executive body, as well as creating and establishing the powers of the respective supervisory bodies;

5) approving annual reports and balance sheets and distributing the company's profits and losses;

6) resolving any issue of acquisition of a participant's share (stake) by the company;

7) expelling a member from the company;

8) making a decision on the liquidation of the company, appointing the liquidation committee, and approving the liquidation balance sheet.

${ }^{122}$ Civil Code of Ukraine, supra note 98, Article 141. 
The articles of association of the company and the law may give exclusive competence to a general meeting to make decisions on other issues. Issues coming under the exclusive competence of the company's general meeting cannot be delegated to the company's executive body.

The decision of the general meeting is adopted if more than 50 per cent of a quorum voted for it. A quorum constitutes 60 per cent of members. In some cases, such as amending the company's articles, changing the amount of the authorized capital, expelling a member from the company, making a decision on liquidation of the company and certain other matters, ${ }^{123}$ a decision shall be adopted by a majority of no less than 50 per cent of votes by existing shareholders (not a quorum). By-laws (articles) can specify a higher percentage for adopting a decision, but cannot reduce it.

Many countries foresee cumulative voting as a compulsory type of voting when electing directors. As Kevin McGuiness explains, "Cumulative voting is a system of voting under which each elector has a number of votes determined by reference to the number of officers that are to be filled by election, with the elector being free to distribute those votes among such number of persons or concentrate those votes on any one person, as the elector may see fit" ${ }^{\prime 124}$.

According to Ukrainian law there, is no compulsory cumulative voting regarding any important decision. Of course, by-laws can provide for cumulative voting; however,

\footnotetext{
${ }^{123}$ See Law “On Business Associations", supra note 102, Article 59.

${ }^{124}$ Kevin P McGuiness, Canadian Business Corporation Law, 2nd ed (Markham,
} Ontario: LexisNexis Canada Inc, 2007) at 771. 
practice shows that this kind of voting is extremely rare, and generally speaking, its rarity is understandable. First, majorities do not have incentive to share their power. Second, many people do not know that cumulative voting is a possibility. It first appeared as an option in Ukrainian law in 2008 with the enactment of the law "On Joint Stock Companies", which provides that unless the by-laws otherwise specify, members of the board of directors and supervisory boards are elected by cumulative voting ${ }^{125}$. But again, by-laws can change this rule and may not provide the minority with real participation in the election of directors. Moreover, the Law "On Joint Stock Companies" does not apply to an LLC. The Civil Code and the Law "On Business Associations" do not mention cumulative voting. However, because civil law is private law, meaning that a person can do anything not prohibited, the inclusion of cumulative voting in the company's by-laws will not contradict Ukrainian legislation. However, as mentioned, the cumulative voting provision is rare in regard to Ukrainian LLCs.

The same position regarding cumulative voting exists in Germany. German legislation does not stipulate compulsory cumulative voting when electing a board of directors. However, it is also not prohibited. Thus, by-laws may provide for compulsory cumulative voting in some cases.

Because a Ukrainian LLC does not consist of shares, there is no class voting at all. All shareholders have the same rights; the only difference is in the number of the stakes and a resulting difference in influence on decision making. As we know, shareholders carry out their voting rights at general meetings. Consequently, the right to convene the

${ }^{125}$ Law “On Joint Stock Companies”, supra note 103, Article 42. 
meeting and to make proposals to meeting agendas is important and related to voting rights.

Ukrainian law provides for the procedure of calling a general meeting at shareholders' request. Pursuant to Article $61,{ }^{126}$ shareholders who overall have more than 20 per cent $^{127}$ of votes may request to call a general meeting at any time and for any reasons that relate to the company's operations (activities). If the "head of the company" does not meet their request within 25 days, the shareholders who made the request may call a general meeting. The only problem is that the legislation is silent on the question of reimbursing expenses incurred by shareholders connected with calling a meeting. Thus, unless otherwise agreed upon in by-laws, shareholders who intend to call a meeting have to be ready to pay for the preparation of the meeting, and no one is required to reimburse them for their expenses. As each coin has two sides, the issue of reimbursement is seemingly irresolvable: Some think that if a shareholder has a right to convene a meeting, he/she should not pay for exercising of this right. Others are sure, however, that if a shareholder can at any time call a meeting and does not have to pay for it, he/she can simply abuse his/her right, which will negatively affect the company.

${ }^{126}$ Law “On Business Associations”, supra note 102, Article 61.

${ }^{127}$ In Germany, shareholders whose interests represent at least $1 / 10$ of the share capital can demand a meeting. See Gesetz betreffend die Gesellschaftcn mit beschrankter Haftung (The Private Limited Act), $<$ http://www.archive.org/stream/germancommercial00germuoft/germancommercial00ger muoft_djvu.txt> at paragraph 50 [The Private Limited Companies Act]. 
The other problem connected to the right to call a meeting is when shareholders who could call the meeting do not indicate when they want to convene the meeting. In other words, a shareholder submits a request to the "head of the company" requesting the convening of the general meeting in the following way: "... thus, based on aforementioned, I request to convene the general meeting”. The head of the company responds to say that upon consideration of the application, he/she has assigned the day of the meeting to be six months from now. According to Ukrainian law, a director has not breached any law in this case and, moreover, has complied with the request, because de jure, he/she fixed a date for the meeting. If this happens, a shareholder cannot do anything except wait.

In Germany the procedure of calling a general meeting is slightly different. According to Paragraph 37 of Civil Code of Germany, shareholders who overall have more than 10 per cent of votes may request to call a general meeting at any time and for any reasons that relate to the company's operations (activities) ${ }^{128}$. If the request is not granted, the local court may authorize the members who made the request to convene the meeting; it may make orders on the conduct of the chairmanship at the meeting. ${ }^{129}$

Making a proposal to the agenda of the general meeting is the next right relating to voting. The right of a shareholder to make a proposal means that a shareholder is entitled to submit to the corporation any questions that must be raised at the general

\footnotetext{
${ }^{128}$ Civil Code of Germany, supra note 104, Paragraph 37 (1).

${ }^{129}$ Ibid, Paragraph 37 (2).
} 
meeting. In Ukraine any shareholder, no matter the per cent of votes that he/she has, can propose any questions for the general meeting agenda. The only requirement for this is time. A shareholder has to submit his/her question to the company not less than 25 days before the meeting. There is no possibility for a director or the "head of the company" to refuse a shareholder's proposals. Moreover, Ukrainian legislation foresees the possibility of adding some questions to the agenda of the meeting on the date of meeting, but only on the condition that all shareholders present at the meeting agree. ${ }^{130}$

In contrast to Ukraine, the German Private Limited Companies Act in Paragraph $50^{131}$ stipulates that a number of members, the aggregate amount of whose shares is not less than a tenth of the company's capital, have a right to demand that a particular matter should be placed on the agenda for a meeting. As can be seen, Ukrainian legislation vests any shareholders with this right; while German law gives this right only to the majority with no less than 10 per cent of the company's capital.

In practice, this right could create problems in its exercise. A head of the company or director must notify shareholders of a meeting no less than 30 days before the meeting. Electronic notification is not appropriate notification in Ukraine. In other words, fax, skype, telephone or e-mail cannot be used by a corporation to notify shareholders. Post (paper) and publication in the newspaper or journal are the usual means of notification in Ukraine. But there is no compulsory provision about publication, and if the by-laws

Law “On Business Associations”, supra note 102, Article 61.

${ }^{131}$ The Private Limited Companies Act, supra note 107, Paragraph 50. 
provide for publication as a means of notifying shareholders, it may not solve all the problems. A director or the "head of the company", if he/she wants to exclude the possibility of adding a question to the agenda, may simply publish a notice in a newspaper that no one knows, or in a newspaper where this notification is least expected to appear, such as in the "Ukrainian Beekeeper" or "Wines of Ukraine". The only requirement is that the newspaper should be national, not local. Of course, in this situation, a shareholder will not be informed in time, if at all. The same tactic can be used to exclude "undesirable" shareholders from voting. In this situation, when there is a publication somewhere, according to law, a shareholder is considered as having been notified and a court cannot help, because a company has fulfilled the requirements.

Using the mail may also cause problems of late notification for proposals. For example, a "head of the company" may intentionally send the 30 days' notification at the end of the day on Friday. The notification will have been lying in the post office for three days without any movement (Friday, Saturday, and Sunday), plus 3-4 days for delivery. In such case the total number of postage days is more than five, and as we know, the shareholder's proposal for an agenda should be submitted no less than 25 days before the meeting. Thus, the director can simply deprive shareholders of the proposal right and, generally speaking, an aggrieved shareholder can do almost nothing because her right is not abused and everything was done within the scope of the law.

As can be seen, there are many problems regarding voting rights in Ukraine and Germany. Generally speaking, almost all of these problems can be solved easily by examining approaches from different countries and by using logical analysis to forge 
suitable solutions to them. In fact, these problems have to be solved as soon as possible, because voting is a fundamental right, one of the most important. Furthermore, voting is the only possible means by which shareholders can participate in the management of the corporation. The absence of real participation by the minority in the management of a corporation could lead to abuse of this right by the majority and the director.

\subsubsection{Right to Information}

Access to information is noted as a major problem for minority shareholders. On this issue, it is observed that "asymmetric information and no access to financial statements in particular is a fiendish problem that a minority shareholder frequently encounters in the real world"132. It frequently happens that the majority gives an order or instruction for management not to provide any documents regarding a company's activities to the minority, especially about pecuniary matters. The majority, in this case, is motivated by two main concerns. The first is that they do not want to disclose some important information to the minority that can be used by an outsider, for example. The second is that the majority feel they are the sole owners of the corporation and do not think it necessary to share with the minority information regarding the company.

The Ukrainian Law "On Business Associations" stipulates the possibility of protecting the right to information. Pursuant to Article 10 (г), each shareholder has the

132 Jianfeng Ji, Protecting Minority shareholders in private corporations: A comparative study from Canadian and Chinese Perspectives (LLM Thesis, University of British Columbia, 2010) [unpublished] at 169. 
right to receive information about a company's activities. On the request of a member of a company, the company shall provide that member with the annual balance, reports about company activities and protocols (reports) of meetings of shareholders. This is the full list of information that it is compulsory to divulge. As to other information such as contracts, original accounting evidence, accounting books and other financial reports, Ukrainian law is silent. Thus, it follows that a director of a company decides on his own whether to provide this other information or not. It is likely, when the majority "kindly ask" the director not give any information to the minority, that the director will refuse minority shareholders' requests for additional information.

In the case they are denied information about the annual balance, reports about company activities and protocols (reports) of meetings of shareholders, the minority is able to bring a lawsuit, which should be quickly and positively resolved for them.

Audit inspection of annual financial reports is connected with the right to information. According to Article 146 of the Civil law of Ukraine, ${ }^{133}$ on the request of any participant of the company, the annual financial statements of the company may be audited by a professional auditor not related to the company or to its participants by property interests. This article also says that expenditures for such an audit shall be charged to the participant on whose request the audit is carried out, unless otherwise established by the company's by-laws. As we know, an audit is not an inexpensive process. Thus, the cost can be, and often is, the deterrent for the minority shareholders to

${ }^{133}$ Civil code of Ukraine, supra note 98, Article 146. 
use this right. However, from a legal point of view, Ukrainian law empowers each shareholder to exercise this power.

In Germany shareholders' right to information is an integral part of the right to convene a general meeting. The general rule is that each shareholder shall upon request be provided with information at the shareholders' meeting by the management board regarding the company's affairs, to the extent that such information is necessary to permit a proper evaluation of the relevant item on the agenda. A general meeting must approve the year's balance sheet, thus, shareholders must be provided with the annual balance, reports about company's affairs and, in general, no more information. Moreover, because shareholders participate in voting during a general meeting, it is clear that they have a right to examine protocols (reports) of any meeting of shareholders. It follows that the director of a company decides on his own whether or not this information is necessary to permit a proper evaluation on the relevant item on the agenda. Hence, he/she has the power not to provide the minority shareholders with some information. In principle, the situation with the right to information is similar in Ukraine and Germany. The only difference is that in Ukraine a shareholder may carry out this right at any time, but, in Germany, only before a general meeting.

As can be seen, the right to information in Ukraine and Germany is not adequately elaborated and needs to be developed. Information in many situations is more significant than money; therefore each shareholder must have equal access to information. 


\subsubsection{Withdrawal from the Company}

The right to withdraw from the company is extremely significant to the minority. This is the last means for minority shareholders to protect themselves against the majority. It is more accurate to say that in this way, the minority does not, actually, protect themselves, but rather takes steps not to lose more than they may already have. It is not a secret that the majority may take measures to secure the lawful oppression of the minority for the purpose of throwing out the minority from the company, and their efforts are often crowned with success. In this situation the minority, in order not to aggravate the relationship between shareholders and management, does not have any choice but to withdraw from the company.

Ukrainian law draws much attention to the withdrawal right and stipulates it in the Civil Code, Commercial Code and in the Law "On Business Associations". The Civil Code of Ukraine provides the most detail on this procedure. It allows the shareholders of a company to withdraw from the company by notifying the company of their withdrawal not later than three months prior to the withdrawal, unless otherwise provided in bylaws. ${ }^{134}$ However, according to Article 100 of the Civil Code, the articles of association cannot stipulate that notification shall be made more than one year prior to the withdrawal. If such a by-law were passed, it would be invalid. In essence the notification would have to be made not later than three months and not earlier than one year from withdrawal. The shareholder that withdraws from a company has the right to receive the

${ }^{134}$ Civil code of Ukraine, supra note 98, Article 148. 
value of the part of its property pro rata to her share in the authorized capital of the company. The agreement between the participant and the company may stipulate that the participant's share may be replaced with a property transfer in kind ${ }^{135}$. In the case that a contribution to the authorized capital was made by means of transfer of the right to use property, the respective property shall be returned to the participant without recompense. The procedure and the method of establishing the value of part of the property pro rata to the participant's share in the authorized capital, as well as the procedure and the terms of its payment, may be established by the articles. If the by-laws do not have any provision regarding the procedure of valuation of the stakes, it is regulated by statutes.

The procedure of withdrawal is outlined in detail in the Recommendation from 28.12.2007 № 04-5/14, "Regarding the practice of the implementation of legislation during litigation proceedings occurring from corporate relations" ${ }^{\prime 136}$, which was issued by the Presidium of the Supreme Commercial Court of Ukraine.

According to Ukrainian law, legal facts ${ }^{137}$ divide into actions and events ${ }^{138}$. An action is something that depends on the will of a person, for example, signing a contract.

${ }^{135}$ Ibid, Article148 (2).

${ }^{136}$ Presidium of Supreme Commercial Court of Ukraine, Recommendation from 28.12.2007 № 04-5/14 "Regarding the practice of the implementation of legislation during litigation proceedings occurring from corporate relations" [Recommendation of Supreme Commercial Court of Ukraine], [translated by author].

${ }^{137}$ In this case, legal facts are the circumstances on the basis of which legal relationships come into existence, change or cease. 
An event is something that does not depend on the will of a person, for instance a death or a hurricane. Transmission of the application to withdraw from a company is an action, which is intended to cease the rights and obligations of a shareholder as a member of a company ${ }^{139}$. This right does not depend on the will of other shareholders or a company. It should be taken into account that a shareholder is considered to be leaving a company from the moment when the general meeting approves a resolution regarding the withdrawal of such a shareholder. In the absence of such a resolution, a person is considered to be leaving a company from the date of expiration of his/her term, which is stipulated by the statutes or by-laws of a company regarding notification for withdrawal from a company ${ }^{140}$.

In Ukraine, a court decision is binding only on the litigants. There are, however, several exceptions. First are decisions from the Constitutional Court of Ukraine. Second, there were several amendments to existing procedural law in 2009, and after 2009, cases considered by Supreme Court of Ukraine can, theoretically, be used as precedents for subsequent judicial decisions in similar situations. Recommendations of Supreme Courts (The Supreme Court of Ukraine, The Supreme Commercial Court and The Supreme Administrative Court) are not compulsory and should be used only as guidance. However,

${ }^{138}$ D V Bobrova, O V Dzera, Civil Law of Ukraine: Textbook: 2 volumes (Kyiv: Jurincom Inter, 1999), online: Ukrkniga <http://ukrkniga.org.ua/ukrknigatext/books/_book-686.htm> [translated by author].

${ }^{139}$ Recommendation of the Supreme Commercial Court of Ukraine, supra note 136 at 3.5 .

140 Ibid. 
in reality, the Supreme Court's recommendations, in their opinions, are "higher than statutes". This applies to the "Recommendation" mentioned above. For example, the Court says that if there is no resolution in a meeting regarding the withdrawal of a shareholder who has submitted an application to withdraw, a shareholder is considered to be leaving the company on the date of expiration of a term as stipulated by the statutes or by-laws of the company for giving notification for withdrawal from the company. But there is no provision to support the position of the Supreme Court. Moreover, it is also impossible to fulfill. This is because the articles of association of a company include the names of shareholders; thus, if someone withdraws from the company, the appropriate changes should be made to the articles. Changing the articles of associations lies in the exclusive power of the company general meeting. Moreover, the changes to the articles of association are valid, not after a resolution of the meeting, but after a registration of the necessary changes in the Registrar's Office. Therefore, the withdrawal application of a shareholder is not an appropriate document for the Registrar, and it cannot make changes to the by-laws.

An application to withdraw from a company is a form of realization of a right, provided by legislation, but not a contract ${ }^{141}$. Because of this feature, no one can say this application is invalid, due to the absence of such a protection in Ukrainian law ${ }^{142}$. Only agreements can be invalid, according to legislation.
${ }^{141}$ Ibid.
${ }^{142}$ Civil Code of Ukraine, supra note 98, Article 16. 
In Germany it can be noted that the statute provides only general provisions regarding the withdrawal remedy. According to Article 39 of the Civil Code of Germany, members have the right to leave an association, and the articles of an association may specify that leaving is permissible only at the end of a business year, or only after a notice period. It also provides that the maximum notice period is two years ${ }^{143}$.

Theory and practice have developed the withdrawal right, which was recognized by the judiciary. ${ }^{144}$ In Ukraine, if a shareholder wants to use this right, she/he will only have to notify a company in appropriate time if otherwise stipulated in the by-laws. In Germany, in addition to notification, a shareholder must provide substantial grounds (wichtige Grund) to leave a company. Wichtige Grund is a key concept in German regulation; it determines whether a shareholder can use the right to withdraw from a company or not. Wichtige Grund in a withdrawal proceeding may be established through any of the following categories ${ }^{145}$ : personal characteristics of the departing shareholder; behavior of other shareholders; or the existence of special factors ${ }^{146}$. The personal characteristics of the departing shareholder may include "financial need, illness,

${ }^{143}$ German Civil Code, supra note 104, Paragraph 39.

${ }^{144}$ Sandra Miller, "Minority Shareholder Oppression in the Private Company in the European Community: A Comparative Analysis of German, United Kingdom and French “Close corporation problem" (1997) 30 Cornell Int'l LJ 381.

${ }^{145}$ Carol Kline, "Protecting Minority Shareholders in Close Corporations: Modeling Czech Investor Protections on German and United States Law" (2000) 23:2 BC Int'l \& Comp L Rev 229 at 240.

${ }^{146}$ Sandra Miller, supra note 144 at 397. 
relocation and inability to fulfill the shareholder role" ${ }^{147}$. The second category - the behavior of other shareholders - may encompass "the arbitrary exercise of majority power or continuation of a dispute among shareholders" ${ }^{\prime 48}$. The existence of special factors - the last category that can be considered as Wichtige Grund - includes, for example, lack of long-term returns on a shareholder's investment or a change in the purpose of the company. ${ }^{149}$ It is important to note that this is not an exhaustive list of the grounds that can be considered as Wichtige Grund. Significantly, as Carol Kline indicates, "neither fault nor exclusion from decision making are necessary to establish Wichtige Grung, thereby making Wichtige Grund broader than U.S. notions of fiduciary duties"150. It is worth mentioning that the articles could also provide the right for withdrawal under specific conditions. However, the articles can only amplify the right of withdrawal, but they cannot restrict or eliminate $\mathrm{it}^{151}$. In other words, no one can take this right from a shareholder: "This right has been grounded on the general principle of good faith and on consideration of respect to long-term relationships that an individual must be able to

147 Hugh Scogin, "Withdrawal and Expulsion in Germany: A Comparative Perspective on the "Close Corporation Problem" (1993) 15 Mich J Int'1 L 127 at 131.

${ }^{148}$ Ibid.

149 Ibid.

${ }^{150}$ Carol Kline, supra note 145 at 240.

151 Robert Fischer et al, GmbH-Gesetz: Kommentar (Koln: O. Schmidt, 1987) at 292. 
terminate them when the circumstances on the basis of which they were entered have permanently and negatively changed"152.

As can be seen, German law provides a more complicated procedure than Ukrainian law for this, because it includes one additional requirement, that is, establishing substantial grounds. In view of this additional requirement, Ukrainian legislation by comparison much more easily protects the minority.

In Ukraine, according to Article 54 of the Law "On Business Association," in the case of the withdrawal of a shareholder from a company, he/she has to receive the value of his part of the company proportional to his stake in the authorized capital of the company. In addition to this, a shareholder must receive a part of the profit for the last number of years. The valuation of her part has to be carried out on the day that a shareholder submits the application.

The biggest problem regarding this right is how to evaluate the stake of a shareholder. There are several possible ways to do this. The first and the best is by agreement. In this case, a shareholder and a company, which is usually represented by the majority shareholders (because they make appropriate changes to the by-laws), negotiate all the conditions. This works when a shareholder wants to leave a company by his own will, in other words, when a shareholder does not have any serious problems with the other shareholders or with the directors, but needs to leave because of some circumstance, such a shortage of money, leaving the country, etc.

\footnotetext{
${ }^{152}$ Hugh Scogin, supra note 147 at 155.
} 
In most cases, however, the minority uses this right as a remedy against a company. It is likely in this situation that no one wants to sit at the negotiation table, and so, a legal proceeding is inevitable. Disputes arising in connection with the withdrawal of a participant from a company, including disputes over the procedure for determining his/her share in the authorized capital, its amount, and terms of payment, must be decided by the court.

In paragraph 3.7 of the Recommendations of the Supreme Commercial Court, the Court gives guidance on how to evaluate the value of the shares. If the by-laws of a company do not provide the procedure for how to evaluate the share of a withdrawing shareholder, the following procedure must be used. According to Article 190 of the Civil Code of Ukraine, property as a specific object shall be considered a separate thing, or a set of things, as with property rights and obligations. According to Article 66 of the Commercial Code of Ukraine, a company's property shall include production and nonproduction assets, as well as other values, the cost of which shall be reflected in a separate balance sheet of the company. Article 66 of the Commercial Code must not be used independently, and has to be analyzed together with Article 190 of Civil Code and Article 139 of Commercial Code, for the following reasons. Article 66 of Commercial Code takes credits (loans) from banks and other lenders as resources constituting a company's property. It is reasonable not to count the credits, but to count only equity capital. For example, if a company has an authorized capital 1000 dollars and takes one million dollars as credit, this does not mean that a shareholder who has $10 \%$ should receive 100100 dollars. He should receive much less. 
Thus, the value of the part of a company that should be paid to a shareholder who withdraws from a company must be calculated from the value of the whole property belonging to a company, including fixed assets, intangible assets, floating assets, nonproduction assets and so on, and also taking into consideration all the liabilities and obligations of a company.

The evaluation of assets is a complicated procedure, which is why Ukrainian law stipulates the possibility of hiring a professional valuator. The problem regarding a valuator is who has to pay for the valuation. Most likely, this is the person who hires the valuator, and most probably, this person is a minority shareholder.

Payment, in the procedure of withdrawal, must be made after approval of the annual report, for the year in which a shareholder withdrew from a company and in a term of not more 12 months from the day of such withdrawal ${ }^{153}$. Ukrainian law, as well as German law, imposes an obligation to pay a fair price to a shareholder who withdraws from a company. However, the question of what is fair is a complicated one that in many situations is not easy to decide. For instance, a small law firm that has five shareholders, each of whom owns twenty per cent and one of whom wants to withdraw from this company that has generated one million dollars of net profit for the last year, and which owns just five tables, chairs, printers, and laptops, and rents its office, would have difficulty evaluating its price. The firm's value is more than its tables, chairs, printers and laptops. But according to the Ukrainian law, this should be the value of the company. But obviously, the value of these tangible assets is not a fair price for the company. The

${ }^{153}$ Law “On Business Associations", supra note 102, Article 54. 
company has its reputation or "goodwill", which is not reflected in its balance sheet, and this can substantially increase its value. It is not the task of the thesis to define the best formula for valuation; however, the problem with valuation is a noteworthy one. In many situations it is impossible to assert that a fair price will be arrived at by using formulas provided in law. The question of a fair price is a major weakness and, thus, is one the biggest problems of this remedy, which can put minority shareholders at a disadvantage.

\subsubsection{Expulsion Right}

Various events in a person's life can change his/her position in a company and his/her relations with its members. It is not rare that because of some conflict between shareholders, or between shareholders and directors, one acts in a way that may negatively affect the corporation and, as a consequence, its shareholders. Simple examples of such actions are: not complying with the company's articles; not executing the resolutions of a general meeting; and disclosing a commercial secret or some confidential information about the company's activities.

With regard to some actions by a shareholder, civil law theory makes it possible to exclude some shareholders from a company, irrespectively of their wishes. In Ukraine, this remedy is stipulated in Article 64 of the Law "On Business Associations". This provides that the shareholder of a company who systematically fails to fulfill, or poorly fulfills, obligations imposed on him/her by the company, or prevents the achievement of the company's goals through her actions or omissions, may be expelled from the company if more than 50 per cent of all shareholders, not only the quorum, passes a 
resolution to that effect. This shareholder would not participate in the vote on this decision $^{154}$.

In light of the above it is necessary to set out the duties of shareholders in Ukrainian companies. The following Article from the Civil Code of Ukraine says the following:

\section{Article 117. Obligations of the members of company}

1. Company members shall be obliged to:

1) follow the company's constituent document and execute resolutions of the general meeting;

2) fulfill their obligations to the company, including those connected with property participation, as well as make contributions (pay for the shares) in the amount and according to the procedure and by means provided by the constituent document;

3) not to disclose commercial secrets and confidential information about the company's activity.

2. Company members may also have other obligations specified by the constituent documents and the law. ${ }^{155}$

Obviously, statutory law imposes few obligations on shareholders. They have no duties to act in the best interest of the company, act fairly in respect of the minority, and so on. However, Article 117 (2) above foresees the possibility of imposing some other duties on shareholders. Nonetheless, constituent documents prepared by shareholders are unlikely to increase the number of duties that they have to fulfill.

\footnotetext{
${ }^{154}$ Ibid, Article 64.

${ }^{155}$ Civil Code of Ukraine, supra note 98, Article 117.
} 
The other cause of exclusion from a company which is stipulated in Article 64 is the prevention, by a shareholder's actions (or omissions), of the achievement of a company's goals. This is very broad notion, and it could give room to the majority to abuse the rights of a shareholder. Theoretically, under this notion can be included any action by a shareholder, such as his/her not coming to the meeting, not voting on some question, and so on. The most common formulation of the reason for expulsion in the resolution of a general meeting, is the "impossibility of achievement of company goals because of systematic absence of the shareholder in meetings, which makes it impossible to pass some resolution". Another common formulation is this: "Because a company's administration is carried out through its organs, and a general meeting of shareholders is the main body, making decisions in the meeting is the duty of shareholders. In light of this, for the systematic non-fulfillment of obligations, which prevents the achievement of company goals, a general meeting passed a resolution according to which the shareholder has to be excluded from the company".

The author of this thesis, strongly disagrees with the position that a person can be excluded from the company for not attending meetings or for not voting for some special question. To vote or not to vote is the right of each shareholder, whether he/she has 1 per cent or 100 per cent of votes, and no one can force a shareholder to come to a meeting. Moreover, no one, not even a court, can force a shareholder to cast his/her vote for any question. This is unacceptable. Indeed, Article 117 of Civil Code of Ukraine does not stipulate attendance of meetings as a duty of shareholders. Furthermore, the Recommendation of the Supreme Commercial Court of Ukraine disapproves of the 
expulsion of a shareholder from a company on the ground of not attending the general shareholders' meeting. ${ }^{156}$

It must be pointed out that this remedy is available to only the majority in Ukraine. It flows from the statute ${ }^{157}$, which foresees that the decision regarding exclusion of a shareholder shall be passed in a meeting by not less than 50 per cent of all current shareholders. Thus, this remedy can only be used by the majority.

A resolution regarding the expulsion of a shareholder from a company shall include reasons for the exclusion, and must specify some act of failure to comply with the by-laws or duties as grounds for the exclusion of the shareholder. The resolution must also specify which facts show systematic non-fulfillment of a shareholder's duties and/or which actions (or omissions) prevent the achievement of company goals. The absence of corresponding information in the resolution regarding the exclusion of a shareholder from a company can be grounds for the nullification of such a resolution by a court where the shareholder brings a lawsuit ${ }^{158}$.

The recommendation of the Supreme Commercial Court of Ukraine provides a very important ruling, according to which, in the case of legal proceedings regarding exclusion of a shareholder from the company, commercial courts have to take into 2.7 .

${ }^{156}$ Recommendation of Supreme Commercial Court of Ukraine, supra note 136 at ${ }^{157}$ Law “On Business Associations", supra note 102, Article 64.

${ }^{158}$ Recommendation of Supreme Commercial Court of Ukraine, supra note 136 at 3.10 . 
account that making a decision regarding exclusion of a shareholder from a company is the exclusive power of a company shareholders' meeting, and is not the power of a commercial court. Thus, a court should only examine the legitimacy and validity (reasonableness) of the meeting's resolution in the case where the excluded shareholder brings a lawsuit to challenge the validity of the resolution ${ }^{159}$. It must be noted that shareholders in a Joint Stock Company do not have a right to exclude shareholders in Ukraine.

According to Ukrainian legislation, the resolution to expel a shareholder should be passed by shareholders, and should not be approved by a court or some other public authority. Because of the significance of such an action, there should be some control over it by a public authority. This is to prevent the majority shareholders from abusing their rights and so offer increased protection to the minority.

German law also foresees the possibility of excluding a shareholder from a company. This remedy, as well as withdrawal, were developed by the court from the right of dissolution of the company. Thus, this remedy can be used only with court approval. Compared to Ukraine where the resolution to expel is valid when more than 50 per cent votes for it, in Germany the resolution must be approved by a court.

${ }^{159}$ Ibid. 
As in the withdrawal right, expulsion can also be authorized by a company's articles; however, the articles may not restrict or eliminate the right of expulsion ${ }^{160}$. This right is guaranteed by law.

If a company's articles do not provide for the procedure, German courts have applied the following elements and the approaches required to fulfill this procedure. First, a company's meeting must vote for the exclusion of a shareholder from the company. The general trend among German courts is to require a supermajority of votes for such a motion to carry. As this right is derived from the right to dissolve a company, the procedure of dissolution of a company shall be used by analogy for the expulsion procedure. A supermajority constitutes $3 / 4^{161}$ of the voting shareholders. In other words, a minimum of 75 per cent of shareholder votes is compulsory to pass such a resolution ${ }^{162}$. The shareholder to be excluded cannot vote on the resolution. This is why "the minority shareholders $[\ldots]$ can force the management of the company by a resolution to initiate proceedings against the majority shareholder and exclude him/her from the company"163. In contrast to Ukraine, in Germany the minority can, theoretically, expel the majority from the corporation. Although expulsion is a decision made in the company's name, the right to determine company policy inherent in owning a majority share is not upheld in

${ }^{160}$ Hugh Scogin, supra note 147 at 157.

${ }^{161}$ The Private Limited Companies Act, supra note 107, Paragraph 60.

162 Ruster Bernd, Business Transactions in Germany (New York: Looseleaf, $1983)$ at $\mathrm{p} 23-144$.

163 Daniel Szentkuti, supra note 11 at 16. 
this context ${ }^{164}$. The possibility for the minority to exclude the majority is confirmed by a landmark case, which held that:

It can therefore happen that a majority shareholder can be expelled by the court upon the decision of a minority if a substantial basis is present. The view of the complaint that it would be grotesque for the minority to be able to expel a shareholder who holds a majority overlooks the fact that a majority position in the company is no carte blanche for conduct in violation of company norms (gesellschaftswidriges Verhalten) ${ }^{165}$.

The main requirement for obtaining the expulsion of a shareholder, like that for withdrawal, is the existence and proof of a substantial basis (Wichtige Grund). Since expulsion is carried out against the will of the affected shareholder, the scope of circumstances that may constitute a substantial basis is narrower than in the case of withdrawal. In the case of expulsion, the substantial basis must lie in the person of the shareholder to be expelled:

Postwar German courts and commentators have resorted to the remedy of expulsion in cases involving factors such as advanced age, extended illness, or mental derangement that make participation in the affairs of the company infeasible. In addition to characteristics such as these, a shareholder's behavior or financial circumstances can also constitute a Wichtige Grund. Examples of these factors include lack of trustworthiness or creditworthiness, disorganized financial circumstances, the loss of personal qualifications mandated by the articles, dereliction of duty, breach of trust, causing incurable dissension among the shareholders, making improper sexual advances, and the like"

\footnotetext{
${ }^{164}$ Hugh Scogin, supra note 147 at 157.

${ }^{165}$ Judgment of Apr. 1, 1953, 9 BGHZ at 178.

${ }^{166}$ Hugh Scogin, supra note 147 at 160.
} 
It is important to note that, in Germany, such substantial bases include misconduct and fault on the part of the expelled shareholder. In these situations it is not hard to justify the expulsion. Yet other reasons for expulsion exist: "Courts and commentators have consistently held that misbehavior or fault, while constituting a substantial basis, is not a necessary element for expulsion. Many of the actionable bases listed above involve no notion of fault whatsoever" ${ }^{\text {"167}}$; for example, old age, financial difficulties, and situations in which the continued presence of one shareholder is intolerable for the others. Also, German courts pay attention to the relationship between the expelled shareholder and others. The most common justification is to show to the court that a company cannot work normally because of some shareholder, and justification constitutes the unbearableness standard (unertrdglich). As can be seen, this is also a very vague and broad notion, which gives very significant power to judges, and shareholders who want to expel someone from a company.

In both Ukrainian and German legislation, an expelled shareholder must be paid the value of his/her share. Common practice is to fix a market value, but as was considered in the previous remedy, it is hard, if not impossible, to determine what this value should be.

In contrast to Ukraine, German legislation makes it possible to expel the majority from the company. However, it is more a hypothetical possibility than a real one. It is hard to imagine that the minority can find enough money to pay to the majority upon its expulsion.

${ }^{167}$ Ibid. 
Another problem with this remedy is the high probability that the majority will expel the "unnecessary" (undesirable) minority from a company, especially in Ukraine, where there is no obligation to approve the resolution by the court decision. The scheme regarding exclusion of the minority works in the following way in Ukraine. The majority makes amendments to the articles of association, thereby imposing more obligations on current shareholders. This is fully lawful, because the Civil Code of Ukraine explicitly foresees this possibility in Article 117, which says that company members may have other obligations specified by constituent documents and the law. This allows for as many duties as possible to be imposed on shareholders. Examples of such duties include that shareholders must be present at each director's meeting to "help" the directors make decisions; or that each shareholder must attend all training provided by the company; or that each shareholder must notify the company and its shareholders about any credits taken by his/her family. After amendments to the articles, the majority can simply wait for the breach of some duty, and can even increase the likelihood of this by, for example, scheduling training days when some shareholders are not able to come. After 2-3 formal "breaches" of duties, the majority can convene a meeting to exclude an "offending" shareholder. Under the law, this is a "neat job" (clean job), and usually the excluded shareholder cannot protect his right to membership. This is because the civil law system is a normative or formal law system where there is no overriding concept of justice. If, in a civil law country, a statute says that a murder is legal, it means that no one can be arrested or put in prison for murder despite its immorality and unfairness. Thus, if everything is formally or procedurally correct, an oppressed shareholder cannot protect his/her interests by a court action. 
In Germany, the success of the foregoing contrivance is less probable because of the need for court approval, thought it is still possible. In a civil law country, a court cannot interpret the law, and it cannot go beyond the scope of the plaintiff's claim. In our case, if an excluded shareholder asks the court to invalidate the resolution, he/she has to show the court evidence to confirm the breach of a procedure, or a breach of his/her shareholder rights. Assumptions, moral principles and unfairness are not valid evidence in Ukraine and in Germany. A judge must cite laws, and if there is no breach of law, any action is correct and legal because of the private law principle that it is possible to do anything not prohibited by the law.

\subsubsection{Dissolution of a Company}

The dissolution of a company involves winding up corporate affairs, selling the corporation's assets, paying corporate debt, and distributing the remaining capital to shareholders on a pro rata basis ${ }^{168}$. Dissolutions of companies are traditionally divided into two categories: voluntary dissolution and involuntary dissolution.

One task of this thesis is to show how the minority shareholder can protect himself/herself. As such, this section examines involuntary dissolution, which is initiated by a shareholder and should be considered by the courts.

${ }^{168}$ Adam Chernichlaw, "Oppressed Shareholders in Close Corporation: A Market Oriented Statutory Remedy" (1997) 16 Cardozo L Rev 501 at 517. 
Professor Sarah Bradley rightly points out that dissolution, as a remedy, is the "most drastic and will generally only be awarded when other remedies would be inappropriate or inadequate" 169 . It is true that this remedy should be awarded only in extreme situations and very rarely. If we recognize that a company is a separate person from any of its shareholders, and that if it is able to continue operating, a court must try to award some other remedy than dissolution. Only after the impossibility of different remedies to deal with identified problems should a court award dissolution. It is commonly said in Ukraine that: "A bad peace is better than a good war". That is why a court, by its action, must seek to ensure the continued operation of a company.

As a remedy, dissolution is completely unknown to Ukrainian law. According to Ukrainian law, a company can be liquidated in the following situations:

- in connection with the expiration of the term and the achievement of the goal for which this legal entity has been created ${ }^{170}$

- by the decision of the court in recognition of the legal entity's ineffective state registration due to violations made in the course of its creation that cannot be removed $^{171}$

${ }^{169}$ Sarah Bradley, supra note 119 at 77.

${ }^{170}$ Law “On Business Associations”, supra note 102, Article19.

${ }^{171}$ Civil Code of Ukraine, supra note 98, Article110. 
- if the value of a legal entity's property is insufficient to meet creditors' demands, the legal entity shall be liquidated according to the procedure established by the law for the renewal of its solvency or recognition of its bankruptcy ${ }^{172}$

- by the resolution of a general meeting of shareholders; ${ }^{173}$

- in case of exceeding a certain number of shareholders; ${ }^{174}$

- based on other reasons stipulated in the articles.

Given the above, there is no provision regarding the possibility for minority shareholders to bring a claim for dissolution in order to protect their interests. However, theoretically the articles of association may provide such a remedy. Even so, the majority shareholders are not likely to stipulate the possibility to dissolve a corporation in any other circumstances, and thereby give more rights to the minority.

In Germany the case with dissolution is somewhat different than in Ukraine. According to the Private Limited Liability Company Act, a company can be dissolved under the following circumstances ${ }^{175}$ :

- expiration of the period specified for its duration in the articles of association;

${ }^{172}$ Ibid.

${ }^{173}$ Law “On Business Associations”, supra note 102, Article19.

${ }^{174}$ Civil Code of Ukraine, supra note 98, Article141.

${ }^{175}$ See, The Private Limited Companies Act, supra note 107, Paragraph 60. 
- a resolution of the members; such a resolution must, in the absence of anything appearing to the contrary in the articles of association, be supported by a majority embracing at least three-fourths of the votes given;

- an adjudication of bankruptcy.

In addition to the above-mentioned situations, a company can be dissolved by an order of the court in the case that the object for which it was formed becomes unattainable or in the presence of other substantial grounds (Wichtige Grund) connected with the affairs of the company ${ }^{176}$. In these cases, the action demanding dissolution must be brought against the company. Moreover, it can only be brought by a certain number of members, the aggregate amount of whose shares represent at least a tenth of the capital ${ }^{177}$.

In general, the position regarding dissolution is different in Ukraine and Germany. The most important distinction is that the German law provides the possibility for minority shareholders to bring a lawsuit in order to dissolve a company.

Clearly, as a remedy, dissolution should be employed only in the case of a deadlock, that is, in case that a company cannot continue to operate. If a company is able to operate, the court should award a remedy, such as withdrawal or expulsion. If a company is seen as a separate entity from its shareholders, and given the significance of a company as a component of the whole economy, all possible efforts must be made to save it. Dissolution, as a remedy, should be employed rarely and only in extraordinary

\footnotetext{
${ }^{176}$ Ibid, Paragraph 61.

${ }^{177}$ Ibid.
} 
situations. It is better to operate without one, two or even thousands of shareholders, than to completely dissolve a company.

\subsubsection{Derivative Action (Suit) and Direct Action}

The separation of a legal entity from its shareholders is the main rule of corporate law. Because of this, the general rule is that only a company can be a complainant regarding its business affairs. In other words, a director, as a representative of a company, can bring a lawsuit on behalf and in the name of a company. Neither majority nor minority shareholders can make an action to protect the interests of a company. However, it is common that management, using its power, may not act in the best interest of the corporation. In this situation, it is unlikely that a director will bring a lawsuit against $\operatorname{him} /$ herself.

The common law developed several exceptions to this rule so that individuals could sue by themselves, or on behalf of a company (derivative action). The following situations allow for exceptions to the rule, to allow a shareholder to bring an action:

- if directors or officers act in an "ultra vires" manner; ${ }^{178}$

- if directors or officers holding the majority of shares use their shares to approve fraud or breach of fiduciary duty committed against the company by themselves or their associates; ${ }^{179}$

${ }^{178}$ Simpson v Westminster Hotel Co (1860) 8 HLC 712. 
- "if the directors or officers infringe on an individual right of the complainant"; ${ }^{180}$

- If the decision requires a special resolution rather than an ordinary one. ${ }^{181}$

Although the derivative action is widely recognized in common law countries, it is not so recognized in civil law countries, such as Ukraine and Germany.

Modern Ukrainian corporate law is not familiar with the concept of a derivative suit. Its emergence there is closely related to historical developments when the idea of the impossibility of combining the interests of the corporation with the interests of its shareholders was supported by scholars in the USSR. Thus, today the situation regarding derivative action has begun to change. One famous Ukrainian scholar, O. Vinnik, in both her book ${ }^{182}$ and her article, ${ }^{183}$ suggests that a derivative suit is a necessary protective mechanism of the rights that belong to shareholders of business associations ${ }^{184}$. Moreover, if Ukraine wants to be a part of the European community, it has to adopt some EU directives, including directives on this issue.

179 Stephanie Ben-Ishai \& Poonam Puri, "The Canadian Oppression Remedy Judicially Considered: 1995-2001” (2005) 30 Queen's LJ 79 at 86.

${ }^{180}$ Ibid.

${ }^{181}$ Edwards v Halliwell, [1950] 2 ALL ER 1064 (CA).

182 O Vinnik, Commercial Law in Ukraine (Kyiv: Jurincom-Inter, 2008) [translated by author].

183 O Vinnik, "On the Question about the Improvement of the Business Associations in Ukraine" (2000) 9 Pravo Ukraini 39 [translated by author].

${ }^{184}$ Ibid at 39 . 
Nowadays, in Ukraine, a shareholder can bring a lawsuit on his behalf, rather than on behalf of a company, in the following cases: According to the Recommendation of the Supreme Commercial Court, corporate disputes also include disputes brought by shareholders regarding the invalidation of a contract signed by a company; in this case a plaintiff will justify his/her claim by the breaching of his right and interest ${ }^{185}$. In addition to this, Article 12 (4) of the Commercial Procedural Code of Ukraine ${ }^{186}$ foresees that a party to a corporate dispute can also be a former shareholder. Thus, disputes regarding the invalidation of a resolution on a question concerning the expulsion of a former shareholder, and disputes in regard to the collection of a company debt in the case of withdrawal, if a company has not paid the required amount of money at all, or has paid only in part, can be also brought by the shareholders. ${ }^{187}$

It follows that in Ukraine a shareholder can bring a lawsuit when his/her own rights as a shareholder have been breached. The action cannot be brought on behalf of a company, and the shareholder must cover all expenses personally. In the situation that a director does not act in the best interest of a company, causing the dissatisfaction of the majority shareholders, the majority is able to pass a resolution to compel a director to bring a lawsuit on behalf of the corporation. According to Ukrainian law, such a 1.2 .

${ }^{185}$ Recommendation of Supreme Commercial Court of Ukraine, supra note 136 at ${ }^{186}$ Commercial Procedural Code, supra note 101, Article 12 (4).

${ }^{187}$ Recommendation of Supreme Commercial Court of Ukraine, supra note 136 at 1.3 . 
resolution must be passed in a general meeting, and it binds everyone in the company: shareholders, employees, and management (if different from employees).

If a director does not comply with this resolution, shareholders have several options. The first is to convene a new meeting, change the director, and compel the new director to bring a lawsuit against the former director on the grounds of failure to implement the resolution. In this case, the lawsuit is certain to succeed, but it is hard to determine the losses of the company. In addition to this, it is necessary to remember that as a general rule, the director's liability cannot exceed his one-month salary. The better option is for shareholders to prove a director's self-enrichment through kickbacks or bribes, or show that he has exceeded his authority, and then bring an application to open a criminal case ${ }^{188}$. If such a case were opened, as a part of a criminal procedure it would be possible to bring a civil lawsuit too in Ukraine. If someone brings a civil lawsuit as a part of the criminal process, in this situation a person has unlimited responsiblility. In other words, the general rule of labor law (liability cannot exceed one-month salary) does not apply in this situation. The third option is only theoretical and is not contemplated in any of the literature reviewed for this thesis. It is also not found in doctrine nor in judicial practice. Nevertheless, the approach is derived from the understanding of a company. As we know, shareholders constitute a company, and they form its organs. Therefore, it can be assumed that the power of the board of directors is derived from the shareholders. Shareholders, in that case, are synonymous with a "shareholder's meeting", which is the

${ }^{188}$ The most common crime in this situation is fraud. 
highest body in a company. Thus, the power of directors is the power delegated from the shareholder's meeting. In a very simple sense, this is similar to the practice of giving power of attorney to someone. Thus, if a director does not want to bring a lawsuit on behalf of the company, the shareholders, by passing the resolution, can do it. Though it is very simple, it does not work in Ukraine, because there only a director is a representative of a company, not shareholders.

Therefore, in Ukraine, only the majority can, theoretically, induce a company to bring a lawsuit against management. In the situation that a director is an "executor" of the majority's will, the minority shareholder's rights can be abused without the possibility of bringing an action on behalf of a company; in other words, minority shareholders cannot protect their interest by using this remedy. It is clear that Ukrainian law has to change this approach.

This remedy is more fully developed in Germany than in Ukraine. The German $\mathrm{GmbH}$ is also a separate legal entity. This means individual shareholders' rights of enforcement against a GmbH's organs are prohibited. In other words, German law does not give the right to an individual shareholder to compel the company's organs to act in accordance with their duties ${ }^{189}$.

\footnotetext{
${ }^{189}$ Yuliya Treschinskaya, Protection of members of Limited Liability Companies in Ukraine in comparison with Germany (LLM Short Thesis, Central European University, 2008) [unpublished] at 25.
} 
Another question is whether shareholders can bring an action on behalf of the corporation for harm caused by the organs of the corporation, which are management or other shareholders, if they have violated their duties towards a company ${ }^{190}$. The answer to this question relates to the fact that a director is an agent of a company, and agency relations create fiduciary duties. In Germany these duties consist of two elements: the duty of care and the duty of loyalty.

The duty of care is explicitly outlined in Article 43 of the Private Limited Companies $\mathrm{Act}^{191}$, which says that the managers must apply the diligence of careful businessmen to the conduct of the business. German law has interpreted the duty of care through the so-called business judgment rule, which is a traditional approach in common law countries, especially the US and Canada. However, in Germany, the business judgment rule is interpreted differently than in common law countries, with the purpose "not to discourage the risk-taking and entrepreneurial activity of the directors" $" 192$.

The duty of loyalty is not established under the Law on $\mathrm{GmbH}$; however, it has been developed and recognized by the courts ${ }^{193}$. "In contrast to the German Stock

${ }^{190}$ Sandra Miller, supra note 144 at 382.

${ }^{191}$ The Private Limited Companies Act, supra note 107, Paragraph 43.

${ }^{192}$ Pierre-Henri Conac, Luca Enriques \& Martin Gelter, Enforcing self-dealing Constrains on Dominant Shareholders in Europe, online: University of California, Berkley $<$ http://escholarship.org/uc/item/5fp568xk\#page-1>.

${ }^{193}$ Detlef Kleindiek, "Protection of Minority Shareholders under German Law" (1993) 4 Int'l Co \& Com L Rev 141 at 141. 
Companies, the relationships between shareholders and managers of $\mathrm{GmbH}$ are characterized by the great degree of co-operation and personal trust" ${ }^{\prime 194}$.

Not only do the directors of a company owe the duty of loyalty, majority shareholders also owe it. This is confirmed by the opinion of the German Federal Supreme Court (Bundesgerichtshof): "The possibility for the majority of shareholders to exercise influence on the management and, therefore, to interfere with the business interests of the other shareholders requires as a counterpart the legal obligation to consider these interests" ${ }^{\prime 195}$. Moreover, in Germany, each shareholder owes a certain duty of loyalty both to the company and to other shareholders.

In the $\mathrm{GmbH}$, the shareholder's right to bring a lawsuit on behalf of the corporation (actio pro societate) is stipulated under certain conditions. According to Article 46 (8) of The Private Limited Companies Act ${ }^{196}$ shareholders, in the general meeting, can decide whether to bring an action against directors or shareholders for damage that they did to the company or not. Of course, this resolution can only be passed by the majority. However, as mentioned earlier, the majority owe a duty of loyalty and, thus, an individual shareholder may bring a lawsuit only in the case that the majority decline to pass a resolution regarding bringing an action against shareholders or a director, thereby breaching the fiduciary duty.

\footnotetext{
${ }^{194}$ Yuliya Treschinskaya, supra note 189 at 26.

${ }^{195}$ ITT-decision (1975) 65 BGHZ 15 at 19.

196 The Private Limited Companies Act, supra note 107, Paragraph 46 (8).
} 
Thus, in German law, there is no statutory basis for derivative suits in a $\mathrm{GmbH}$, although the possibility is generally recognized by scholars, and, most importantly, by courts. However, in Germany, as well as in Ukraine, many scholars consider that the shareholders' option to bring a lawsuit against directors who act dishonestly is nearly impossible to act upon ${ }^{197}$. As a result, a lawsuit against a director for bearing a liability has always been rare in Germany ${ }^{198}$. Most common is a lawsuit brought by the company against management after a change of management, or by the bankruptcy trustee in the process of bankruptcy. Therefore, German law devotes numerous statutory provisions to the regulation of related party transactions ${ }^{199}$; however, it also gives an individual shareholder "almost no tools to enforce these provisions"200.

It follows that direct action in civil law countries cannot, for the most part, protect majority shareholders, because it is hard to prove the breach of shareholders' rights or directors' duties. As for the derivative action, in Ukraine it is not recognized at all, and in Germany it is recognized but still hard to exercise and, thus, is almost useless. In Germany and Ukraine, it is hard to protect the minority's interests because the "Majority Rule" is too strong.

${ }^{197}$ Reinier Kraakman et al, The Anatomy of Corporate Law: A Comparative and Functional Approach (New York: Oxford University Press, 2004) at 128.

${ }^{198}$ Yuliya Treschinskaya, supra note 189 at 27.

${ }^{199}$ See pages 270, 282 Frank Dornseifer, Corporate Business Forms in Europe: A Compendium of Public and Private Limited Companies in Europe (Munich: Sellier European Law Publishers, 2005).

${ }^{200}$ Yuliya Treschinskaya, supra note 189 at 27. 


\subsubsection{Stakes Not Shares}

As mentioned earlier, in Ukraine, there are no shares in the Limited Liability Company. At first glance, it does not matter whether a shareholder has 1000 shares constituting 30 per cent of all stakes (votes), or has just 30 per cent of the stakes in a company. But in fact this difference does matter. The Law "On Securities and Stock Exchange" provides that,

A share shall be a registered security that certifies the property rights of its owner (shareholder) that relate to the joint stock company, including the right to receive a portion of the profit of the joint stock company in the form of dividends, the right to receive a portion of the property of the joint stock company in case of its liquidation, the right to manage the joint stock company as well as non-property rights envisaged by the Civil Code of Ukraine and the law that regulates the establishment, operation and termination of joint stock companies. ${ }^{201}$

Pursuant to Article $177,{ }^{202}$ objects of civil rights shall be things, including money and securities, other property, ownership rights, results of work, services, the results of intellectual and creative activity, information, as well as other tangible and intangible welfare. This definition shows that securities, which include a share, constitute "things". Thus, an item of the material world with respect to civil rights and obligations may arise and shall be recognized as a "thing"203.

${ }^{201}$ Law “On Securities and Stock Exchange”, 23.02.2006 № 3480-IV, online: Official website of the Verkhovna Rada of Ukraine (Parliament) $<$ http://www.rada.gov.ua $>$, Article 6 [translated by author].

${ }^{202}$ Civil Code of Ukraine, supra note 98, Article 177.

${ }^{203}$ Ibid, Article 179. 
Therefore, a share is a special kind of thing - an object of civil right. This means that a share may be freely alienated or transferred from one person to another under the procedure of succession or inheritance, or by other means ${ }^{204}$. In other words, a share is something similar to, for example, a house. One can sell it or grant it to someone and, most importantly, one's heirs can and will inherit it.

However, one problem with this exists at the theoretical level. Ukraine, like Russia, has changed the law regarding shares. Nowadays, it is not possible to issue a paper form of a share. The elimination of shares as documents raises a question regarding the presence of one element of ownership title - the title to possess. According to civil law, each "thing" (a share is a thing) must have an owner and be material. Ownership, in Roman law, means that the owner of a thing has the titles to possess, use and dispose of his property. Often, these three titles are called the "triad of ownership titles". If there is a non-documentary share, what does a shareholder possess if there is no material (factual) "thing", but only a juridical fiction ${ }^{205}$ ? For, materially, there is no share at all. Factually, an owner of non-documental shares is per se a nominal owner ${ }^{206}$. Acknowledgement of ownership of the rights (because he is a nominal owner), and not only of the "thing", implies the truncation of the classical "triad of ownership titles" and, consequently,

${ }^{204}$ Ibid, Article 178.

${ }^{205}$ Wolters Kluwer, The Nature of Shares, online: Wolter Kluwer Russia $<$ http://www.wolters-kluwer.ru> at 5. See also, V A Belov, Securities in Russian Civil Law (Moscow: UrInfoR, 1996) [translated by author].

${ }^{206}$ Belov, supra note 205 at 5. 
changes the whole theory of Civil Law ownership. However, this question is out of the scope of this paper.

Regarding a stake, the question of its nature is unintelligible. The legislatoion does not provide any definition of what a stake is or of its nature. Theoretically, using systematic analysis, we can come to an important conclusion. The Laws "On Joint Stock Companies" and "On Business Associations" as well as the Civil and Commercial codes, stipulate that shares and stakes grant to their owners property rights and non-property rights (receiving dividends, participation in the management of a corporation, receiving information and so on).

Property rights, together with things, form the notion of property. This is confirmed by Article $190^{207}$ : Property as a specific object shall be considered a separate thing or set of things, as well as property rights and obligations ${ }^{208}$. As noted a thing is an object of the material world, which is something that exists such that one can touch or hold it. A stake is obviously a "legal fiction", thus it cannot be recognized as a thing. Consequently a stake is a combination of property and non-property rights, but it is not a thing.

Accordingly, the legal status of stakes and shares are different. A share is a thing, which gives its owner combinations of rights. A stake, in turn, is a combination of property and non-property rights, which is derived from membership in a business association.

${ }^{207}$ Civil Code of Ukraine, supra note 98, Article 190.

${ }^{208}$ Ibid. 
These differences in the legal nature of shares and stakes cause problems. The first is a problem as to succession. Pursuant to Article 1219 of Civil Code of Ukraine, rights and obligations inseparably connected with the testator shall not be included in an inheritance, particularly the right to participate in a business association and the right to membership in associations of citizens, unless otherwise established by law or the constituent documents ${ }^{209}$. At first glance, this is a fitting provision. However, it is not so fitting. Even if constituent documents allow for the possibility of inheriting stakes, this provision is impossible to fulfill without a condition, and the biggest problem with this condition is majority shareholders. In contrast to a Joint Stock Company where anyone who has shares is granted some rights, in a Ukrainian Limited Liability Company, these rights are granted to one whose name appears in the articles. Thus, to elect a new member of a company, the general meeting must pass a resolution by which to modify the articles. Moreover, this resolution must be passed by the majority, with no less than $3 / 4$ of the votes $^{210}$. Hence, it is up to the majority whether or not to admit a new member.

The second problem is associated with selling stakes. If a shareholder sells his stake, a new shareholder obtains the rights and the status of the old shareholder, again, only after changing the articles of association. Thus, it is impossible to sell a stake to a third party without the permission of the majority. In this situation, a buyer is not guaranteed to become a new shareholder of company. Evidently, even a court does not

\footnotetext{
${ }^{209}$ Ibid, Article 1219.

${ }^{210}$ Ibid, Article 98 .
} 
have the power to force the shareholders' vote on some question in the meeting. It is up to shareholders whether to vote or not and no one can force them to do this.

There is a practice that solves the second problem. To protect the buyer of a stake, a shareholders' resolution must be prepared under which the necessary number of shareholders vote for the inclusion of a new member in the articles of association and the withdrawal of a previous member, who is the seller. This resolution must be fully prepared (with all appropriate signatures and stamps, but without a date). The seller then takes this resolution and goes with the buyer to a notary. In exchange for money, the seller gives this resolution to the buyer and a notary certifies and dates the resolution. The buyer, with the "rightful" document, goes to the Registrar's office and the officer changes the articles of association by changing the names of shareholders, based on the resolution.

The second possibility for the secure sale of a stake is the way according to which a seller, in exchange for money, gives a power of attorney to a buyer's authorized representative (trustee) with the right to vote in the general meeting. This authorized representative votes to include the buyer in the shareholders' list of the articles of association and to withdraw a former shareholder (the seller). The second variant is permissible but undesirable on account of the many risks that a buyer bears. First of all, the majority must vote on the decision. If a seller has a majority of the votes $(3 / 4)$, there is no problem. But the biggest risk relates to the nature of a power of attorney. It is common knowledge that a principal can, at any moment, revoke the power of attorney, and this can be a ground for the invalidation of the meeting. In the second option, then, a buyer is not secure and bears very serious risks. 
Concerning a share, on the other hand, everything is much easier. One party, based on the shares' sale agreement, sells, and the other party buys shares. Then a buyer takes this contract and goes to the Registrar's Office. Based on this agreement (not on the resolution of the general meeting, as it is in an LLC), the Registrar's officer changes the name of the owner of shares. For shares, there is no need for shareholder approval. Thus, a sale agreement is the only action needed to transfer the shares.

It is true that in the common law world, a privately-owned company's documents usually stipulate the prohibition of selling shares without the consent of other shareholders or the impossibility of the inheritance of shares by heirs. However, it is important to note that these prohibitions are stipulated in the shareholders agreement or articles of association, and everyone who signs these documents agrees to pursue them. The situation is totally different in Ukraine. The default rules are that the shares can be freely transferred (sold, granted) to any person, and that the heirs do not inherit them. Even if all shareholders agreed, for example, that shares can be inherited, this agreement will not have any legal strength or power and cannot be performed. Moreover, as mentioned, the default rule is that shares can be freely transferred to any person, but in practice this is not the case, because at any time, the majority can block this operation. Even if the constitutional documents of a company stipulate that any shareholder can sell his/her shares without the consent of other shareholders, again, this provision will not work. Thus, in Ukraine, statutes limit in some way the leeway shareholders may have. It is mainly due to the fact that, in this case, the law stipulates default rules which reflect the interests of the majority of people. For the majority of privately-owned companies and in 
most cases, these rules fit, though there are people who are not satisfied with them. Especially for them, it is necessary to provide the possibility of changing the default rules, so long as the change does not contradict relevant statutes and common sense.

Overall, company stakes cause many serious problems that need urgent solution. The Ukrainian legislator should pursue three possible avenues. First, it could cancel stakes and leave only shares. Second, it could recognize a stake as a special non-material thing or give some special status to it and define its nature. Third, it could allow the creation of a unanimous shareholder's agreement granting the power to change some rules and procedures within a company, as in common law countries like Canada. ${ }^{211}$

\subsection{Shareholder Protection under Civil Law: A Summary of Problems}

The preceding discussion set out possible shareholder remedies and their associated problems, especially for minority shareholders, and the ways that the majority can abuse the minority by exploiting their position. It also suggested that minority shareholder protection in Civil Law countries, based on German and Ukrainian law, provide some possible ways of protecting the minority's rights and interests, although, not satisfactorily enough.

In Civil Law countries, the articles of association almost fully define the leeway and the rights of the minority. The articles of association are, however, approved by the majority. Thus, of course, in many situations they reflect the will of the majority. As such,

${ }^{211}$ CBCA, supra note 8, s 146. 
it is likely that the articles of association will not provide favorable options for minority protection, such as by cumulative voting, passing resolutions by the greater number of votes, selling shares to third parties, and enforcement of the obligations of the majority for the benefit of the minority.

Many rights outlined in statutes can be limited or even eliminated by the articles of association. Again, this works against the minority. The withdrawal remedy is a powerful weapon in the minority's arsenal, but sometimes it cannot be used because of the need to prove some extraordinary circumstances. In some cases, it is an extreme remedy, because its use ends the relationship between a shareholder and a company. In many situations, the minority wants to be a part of a company and so does not want to use this remedy. Moreover, it is almost impossible to determine or receive a fair price for shares, as this depends on the concurrence of the majority shareholders.

The expulsion remedy can be a good way to exclude a shareholder that does not act in the best interests of a company. However, some jurisdictions do not provide the opportunity to implement this remedy for the minority (Ukraine), while others, such as Germany, stipulate this possibility for the minority, who may not, however, be able to take advantage of it due to the financial costs associated with doing so.

Direct action may protect the interests of a shareholder and a company itself. However, because of the compulsory requirement to bring a lawsuit to show the breach of a shareholder' rights, some situations cannot be resolved by direct action. 
Derivative action and fiduciary duties are not stipulated at all in civil law countries, such as Ukraine; or they are not well-developed, such as in Germany. These institutions need to be adequately developed to protect both majority and minority shareholders.

There are some problems in Civil Law countries regarding shareholder protection that cannot be resolved for the benefit of the minority. Some of these are:

- If the majority does not pay dividends, but instead, increases their salary and fires the minority from a director position: For instance, if there are 3 directors, and one owns 50 per cent of the shares, and the other two own 25 per cent each, the director who is the majority, can, at the meeting, pass a resolution according to which he/she remains the only director, and can distribute all the profit not as dividends, but as bonus, on top of his/her salary as a director. In this case, the minority does not have the right to bring a lawsuit because their rights as shareholders are not breached. Furthermore, they retain all rights and obligations as shareholders.

- A majority shareholder employs his/her relatives or trusted persons as counselors with huge salaries: These appointees, legally, do nothing but give back some money to the director as a kickback. It works in this way: a director hires, for example, one counselor with the salary of $10000 \$$ per month. Each month, this "counselor" pays back to this director (the majority) $9000 \$$. This means that the real salary of the director is his nominal salary plus $9000 \$$. Again the minority can only helplessly throw up their hands, and nothing more. 
- The majority can use the expulsion right against the minority, which will eventually lead to the exclusion of the minority from a company on some "formal" grounds.

- Because of the "Majority Rule", a minority, de facto, does not participate in the election of the board of directors or supervisory boards.

- If the majority or director(s) do not act in the best interest of a company, the minority cannot bring a lawsuit against them because the minority can bring an action only when their rights as shareholders are breached, but not the rights of a company. A company is a separate legal entity, which itself decides whether or not to sue.

- Very common is a situation where the majority, in conjunction with the director (who may be the same person), sells valuable assets below value to another company, which is also controlled by the majority; or when the director sells the products of a company at a much lower price to another company, which is also controlled by the majority. Again, usually no law is breached in these situations.

The biggest of the problems which are difficult to solve is that in a Civil Law system, a person can bring a lawsuit only if his/her rights are breached. Moreover, a court has less power than its counterpart in a Common Law system. In a Civil Law system, a court cannot interpret law and cannot go beyond the scope of the plaintiff's claim; it can only award the remedy which is stipulated in the law. Thus, even if it is obvious that some action is unfair, and possibly detrimental to someone, but that action is within the scope of the law, a court cannot answer a claim in regard to it. In 
some $^{212}$ Civil Law countries a court does not have the power to award amendments to the constitutional documents of a company, which do not serve the interests of the minority. Thus, a civil law system needs some additional forms of statutory or judicial intervention to facilitate solutions to these problems, which at the moment, cannot be solved in the interest of the minority.

Corporate law develops very fast. Because of this, it is impossible to foresee every possible breach of the law. This is why the Civil Law system must import some remedies from Common Law countries, or contrive some unique ones, which may be too broad but theoretically usable in many situations.

The next Chapter draws on Canadian law to examine possible options to increase minority shareholder protection and to offer some solutions to the above-mentioned problems.

${ }^{212}$ For example, Ukraine. 


\section{CHAPTER IV}

\section{THE SOLUTION: SHAREHOLDER PROTECTION IN THE COMMON LAW SYSTEM}

\subsection{Introduction}

This Chapter suggests possible solutions regarding the protection of minority shareholders against the majority and directors. The solutions suggested here are part of the regimes of corporate law in common law jurisdictions, such as Canada, the United States, the United Kingdom, and Australia. All of these countries provide many more tools to protect minority shareholders than continental countries do. Moreover, these are the leading common law countries, and so, the solutions reflect their experiences and knowledge in protecting minority shareholders and a company itself.

The discussion focuses on the principal means of shareholder protection in the common law, namely: directors' duties; the oppression remedy; and derivative actions. The common law jurisdictions developed these remedies over many years provide for wide discretion in the effort to protect the minority. There are many common law countries in the world, and it is impossible to examine them all, hence these remedies are considered mainly from a Canadian perspective, but also with reference to the United States and England. The argument advanced is that by using these remedies, minority shareholders can be protected against majority shareholders, as well as against directors. 
The remedies do not make it directly possible for minority shareholders to enjoy real participation in the management of a company. A real participation can only be achieved in the case when the minority is able to elect at least one director of the Board. Thus, this section, in addition to above-mentioned remedies, examines cumulative voting as a means for the minority to elect directors.

\subsection{Director Duties}

As outlined in the previous chapters, some civil law countries, such as Ukraine and Russia, do not impose any special duties on a director, except that he/she must act in accordance with the articles of association and laws - in other words, a duty of obedience or ultra vires doctrine. In principle, this is the only special duty imposed on directors. Other countries, such as Germany, provide the duty of care ${ }^{213}$ and the duty of loyalty. Although, the duty of loyalty is not established under the Law on GmbH in Germany, it has been developed and recognized by courts ${ }^{214}$. Nonetheless, because of the general principle of civil law regarding liability, which provides an obligation to prove a director's guilt, damage, and the relationship between the guilt and damage, it is not easy to find a director liable for breach of his/her duties. Moreover, even if a director in a civil

213 The Private Limited Companies Act, supra note 104, Paragraph 43: directors must apply the diligence of careful business men to the conduct of the business.

${ }^{214}$ See Detlef Kleindiek, supra note 193. 
law country exercises his/her power without the "diligence of careful business men,"215 without being "a reasonably prudent person",216 or a "reasonably diligent person," long as that director's imprudence is unintentional, without guilt, it creates an exception as to his/her liability. Clearly, the duty of care and loyalty, even if it exists, is still not adequately developed in civil law countries, compared to duties of directors in the common law world.

Thus, directors' duties have to be expanded in civil law countries, as they are in common law countries. As we know, a director plays a very important role in a company. $\mathrm{He} / \mathrm{she}$ can serve not only in the best interest of a company, but also in his/her own interest. He/she can act selectively in the interest of only some constituencies, such as majority shareholders, leading to the oppression of the minority. In other words, a director can be a means of protection for minority shareholders and the company, but also the biggest means of abuse and neglect of their rights. However, if a director knows that he/she must act not only in the best interest of the majority shareholder, but also in the interest of the minority, and that he/she will be held responsible if he/she does not do this, it is more likely that a director will not abuse minority's rights. In view of these considerations, it is necessary for civil law jurisdictions to borrow from the duty of care and fiduciary duties that common law countries apply to corporate management.

\footnotetext{
215 The Private Limited Companies Act, supra note 107, Paragraph 43.

${ }^{216}$ CBCA, supra note 8, s 122.

${ }^{217}$ Companies Act 2006 (UK), c 46, s 174 [UK Companies Act].
} 
In Canada, the United Kingdom and the United States, these duties developed for many years, and are now widely used to inform both the theory and practice of corporate governance. The duties have, so far, been developed and defined mainly by the judiciary thorough court decisions.

Professor Sarah Bradley observes that: "The duties owed by directors generally fall within three broad categories. The first is the duty of obedience, or the duty to act within one's powers, in compliance with the [laws] and the constitutive documents of the company. ${ }^{218}$ This duty is well elaborated in both common law countries and civil law countries. It constitutes the ultra vires standard. Because of the existence of the duty of obedience in both law systems, this thesis does not consider it in this Chapter. "The second is the duty to act with reasonable care, without negligence; and the third is to act with the loyalty of a fiduciary, to be trustworthy and act in good faith."219

\subsubsection{Duty of Care}

The second duty is the duty of care, diligence and skill, which usually refers to a duty of care. The common law duty of care imposes on directors an obligation to fulfill their work in accordance with prescribed standards to the requisite degree of care and skill. ${ }^{220}$ This duty has been developed mainly by the judiciary, but currently it can be

${ }^{218}$ Sarah Bradley, supra note 119 at 52.

${ }^{219}$ Ibid.

${ }^{220}$ Ibid at 53 . 
found in many common law statutes, such as the $\mathrm{CBCA}^{221}$ and the UK Companies Act. ${ }^{222}$ In the CBCA, for example, this duty is stated to the effect that every director and officer of a corporation, in exercising their powers and discharging their duties, shall exercise the care, diligence and skill that a reasonably prudent person would exercise in comparable circumstances. $^{223}$ The statute does not specify who the reasonable person is and what the comparable circumstances are. However, case law has evolved several standards to guide and inform the actions of directors.

The leading case regarding the duty of care, Re City Equitable Fire Insurance Company Limited, ${ }^{224}$ explains the duty of care. In this case Romer J. said:

A director need not exhibit in the performance of his duties a greater degree of skill than may reasonably be expected from a person of his knowledge and experience. A director of a life insurance company, for instance, does not guarantee that he has the skill of an actuary or of a physician. In the words of Lindley M.R.: "If directors act within their powers, if they act with such care as is reasonably to be expected from them, having regard to their knowledge and experience, and if they act honestly for the benefit of the company they represent, they discharge both their equitable as well as their legal duty to the company." 225 It is perhaps

${ }^{221}$ CBCA, supra note 8, s 122.

${ }^{222}$ UK Companies Act, supra note 217, s 174.

${ }^{223}$ CBCA, supra note 8, s 122 (b).

${ }^{224}$ Re City Equitable Fire Insurance Company Limited, [1925] Ch 407, [1924] All ER REP 485.

${ }^{225}$ Lagunas Nitrate Co v Lagunas Syndicate [1899] 2 Ch 392 at 435. 
only another way of stating the same proposition to say that directors are
not liable for mere errors of judgment.226 Judge Romer continued by observing that a director is not bound to give continuous attention to the affairs of his company: "His duties are of an intermittent nature to be performed at periodical board meetings, and at meetings of any committee of the board upon which he happens to be placed. He is not, however, bound to attend all such meetings, though he ought to attend whenever, in the circumstances, he is reasonably able to do so. ${ }^{, 227} \mathrm{He}$ also observed that, "having regard to the exigencies of business, and the articles of association, [some duties] may properly be left to some other official, ... [and] in the absence of grounds for suspicion, [a director is] justified in trusting that official to perform such duties honestly."228

Moreover, it is important to mention that the law in Canada and the US has the common requirements that the court must be satisfied that the directors have acted reasonably and fairly. The court looks to see that the directors have made reasonable decisions, not perfect decisions. ${ }^{229}$ In other words, perfection is not demanded.

${ }^{226}$ Re City Equitable Fire Insurance Company Limited, supra note 214 at para 428.

${ }^{227}$ Ibid.

${ }^{228}$ Ibid.

${ }^{229}$ Pente Investment Management Ltd v Schneider Corp (1998), 42 OR (3d) 177, [1998] OJ No 4142 (Ont CA). 
In contrast to the subjective standard, "based upon the care and skill which a particular director would reasonably be expected to exercise in light of his/her personals skills and training, ${ }^{, 230}$ the modern common law standard now also includes objective elements. Confirmation of the above-mentioned test can be found in the recent case Equitable Life Insurance Society v. Bowley ${ }^{231}$, where the court pointed out that a director should exercise his/her power as a "reasonably diligent person having both ... the general knowledge, skill and experience that may reasonably be expected [in comparable situations] ... and the general knowledge, skill and experience that the director has."232 The widening of the standard of the duty of care has been in response to practical exigencies. McGuinness observes that, "given the history of the case law in this area [duty of care], and the prevailing standards of competence displayed in commerce generally, it is quite clear that directors were not expected at common law to have any particular business skill or judgment." ${ }^{, 233}$ Moreover, in the 1971 report entitled Proposals for a New Business Corporations Law for Canada (hereafter the Dickerson Report), ${ }^{234}$ the committee came to the same conclusion and gave some objective recommendations regarding the existing standard of duty of care:

${ }^{230}$ Sarah Bradley, supra note 119 at 53.

${ }^{231}$ Equitable Life Insurance Society v Bowley, [2003] EWCA Civ 1114, [2003] 2 BCLC 603 (EWCA).

${ }^{232}$ Ibid.

${ }^{233}$ Kevin P McGuiness, supra note 124 at 776.

${ }^{234}$ Robert W V Dickerson, John L Howard \& Leon Getz, Proposals for a New Business Corporations Law (Ottawa: Information Canada, 1971) [Dickerson Report]. 
Recent experience ${ }^{235}$ has demonstrated how low the prevailing legal standard of care for directors is, and we have sought to raise it significantly. We are aware of the argument that raising the standard of conduct for directors may deter people from accepting directorships. The truth of that argument has not been demonstrated and we think it is specious. The duty of care imposed by s. 9.19(1)(b) is exactly the same as that which the common law imposes on every professional person, for example, and there is no evidence that this has dried up the supply of lawyers, accountants, architects, surgeons or anyone else. It is in any event cold comfort to a shareholder to know that there is a steady supply of marginally competent people available under present law to manage his investment.",236

Taking into consideration the opinions of the committee and scholars, legislators and courts raised the standard of the duty of care. Moreover, to the statutory duty of care was added "in comparable circumstances," which is intended to make "relevant all of the circumstances in which a decision is made, including the qualifications of the particular director, the significance of the action to the director when making the decision, the time available for making the decision, the alternatives open to the corporation, and other factors. ${ }^{237}$ It might also be used to apply different standards to different directors depending on whether the director is an "outside" or an "inside" director, a representative

${ }^{235}$ See, for example Dovey v Cory, [1901] AC 477 (HL); In re Brazilian Rubber Plantations and Estates, Ltd, [1911] 1 Ch 425; and In re City Equitable Fire Insurance Co, supra note 224.

${ }^{236}$ Dickerson Report, supra note 233 at 83.

${ }^{237}$ Robert E Milnes \& Kathleen M Ritchie, Directors' and Officers' Duties and Liabilities, online: Gowling Lafleur Henderson LLP $<$ http://www.gowlings.com/resources/PublicationPDFs/MilnesR_DirectorsMemo10.pdf $>$ at 11 . 
of a special interest group such as workers or minority shareholders, or a professional

advisor to the corporation, such as a lawyer or an accountant.

The Supreme Court of Canada recently summarized the duty of care as follows:

The contextual approach dictated by s.122(1)(b) of the CBCA not only emphasizes the primary facts but also permits prevailing socio-economic conditions to be taken into consideration. The emergence of stricter standards puts pressure on corporations to improve the quality of board decisions. The establishment of good corporate governance rules should be a shield that protects directors from allegations that they have breached their duty of care. However, even with good corporate governance rules, directors' decisions can still be open to criticism from outsiders. Canadian courts, like their counterparts in the United States, the United Kingdom, Australia and New Zealand, have tended to take an approach with respect to the enforcement of the duty of care that respects the fact that directors and officers often have business expertise that courts do not. Many decisions made in the course of business, although ultimately unsuccessful, are reasonable and defensible at the time they are made. Business decisions must sometimes be made, with high stakes and under considerable time pressure, in circumstances in which detailed information is not available. It might be tempting for some to see unsuccessful business decisions as unreasonable or imprudent in light of information that becomes available ex post facto. Because of this risk of hindsight bias, Canadian courts have developed a rule of deference to business decisions called the "business judgment rule," adopting the American name for the rule." 238

Therefore, in assessing whether or not the directors or officers have met their obligations, Canadian courts generally approach the subject on the basis of what has become known as the "business judgment rule." This rule operates to shield from court intervention business decisions that have been made honestly, prudently, in good faith and on reasonable grounds. Specifically, the court will look to see that the directors or

${ }^{238}$ Peoples Department Stores (Trustee of) v Wise, 2004 SCC 68 at para 64. 
officers have made a reasonable decision, not necessarily a perfect decision. ${ }^{239}$ Directors and officers are not likely to be held to be in breach of their duty of care if they have acted prudently and on a reasonably informed basis in light of all the circumstances, including the prevailing socio-economic conditions, about which they knew or ought to have known.

To sum up, this duty forces a director to perform his/her duties with care, diligence and skill that a reasonably prudent person would exercise. The judicial standard requires that a director must make reasonable decisions, not perfects ones. Business decisions sometimes are made with high stakes and under considerable time pressure, and so it is possible to make a wrong decision. However, when a director acts honestly but makes a mistake, the courts protect the director, by resort to the "business judgment rule". Thus, if a director acts within his/her power, if he/she acts with such care as is reasonably to be expected from him/her, having regard to his/her knowledge and experience and taking into consideration the circumstances in which the decisions are made, and if he/she acts honestly for the benefit of a company, it is unlikely that he/she will be liable for the relevant actions.

${ }^{239}$ Robert E Milnes \& Kathleen M Ritchie, supra note 236 at 3. 


\subsubsection{Fiduciary Duties}

In addition to their statutory duty of care and the duty of obedience, in the common law, directors owe the fiduciary duty, which can be described as a duty of loyalty and good faith. The conception of fiduciary duties is intended to protect a corporation against self-dealing, self-interest and bad faith at the hands of its directors or officers. These duties are also codified in many jurisdictions. ${ }^{240}$ The statutes are very broad and vague on this subject, so the duties have been mainly developed by the judiciary. For example, the fiduciary rule under the CBCA says that directors and officers, in exercising their powers and discharging their duties, shall act honestly and in good faith with a view to the best interests of the corporation ${ }^{241}$.

In general, "the fiduciary duties of directors can be divided into three main categories: the duty to act in the best interests of the corporation, the duty of loyalty and to avoid conflicts of interest, and the duty to disclose any interests in corporate transactions." 242

The first element of the fiduciary duty is acting in the best interest of the corporation. The notion of what is the interest of the corporation was considered in detail in the Chapter two. Article 122 of CBCA implies that the CBCA gives wide discretion to the court to decide what the best interests of the corporation are at any time. The

${ }^{240}$ CBCA, supra note 8, s 122; UK Companies Act, supra note 217, s 177.

${ }^{241} C B C A$, supra note 8, s 122 (a).

${ }^{242}$ Robert E Milnes \& Kathleen M Ritchie, supra note 236 at 13. 
Dickerson Committee did not explain what the best interest of the corporation is because they wanted to "leave the law to develop in the hands of the judges."243 This means that the whole matter of deciding whose interest is to be taken into consideration when deciding the best interest of the corporation is left to the court. Apparently, the Dickerson Committee assumed that it will be easier for the courts to decide this matter. They never mentioned that this might involve the courts dealing with the business judgment rule, and that this discretion might be a burden on the courts' shoulders. ${ }^{244}$ The reason behind leaving this issue to the court, as mentioned previously, is that the Committee wanted to avoid any radical changes, and rather, to let the courts make any changes that they think would fit with the Canadian system. It is noteworthy, for instance, that the Alberta Business Corporation Act, ${ }^{245}$ the most recent, totally reviewed provincial legislation on the subject in Canada, agrees with and cites the CBCA to say that this matter should be left in the hand of the courts to develop ${ }^{246}$.

The courts have established rules that a director will be liable as a fiduciary if he/she fails to act in good faith and in what he/she honestly believes to be the best interests of the corporation when carrying out his/her statutory duty of managing the corporation. Traditionally, the courts had a fairly narrow view of what is in the best

${ }^{243}$ Dickerson Report, supra note 233 at 82.

${ }^{244}$ Peoples Department Stores (Trustee of) v Wise, supra note 237.

${ }^{245}$ Alberta Business Corporation Act, RSA 2000, c B-9.

${ }^{246}$ University of Alberta, Proposal for a New Alberta Business Corporation Act (Report No 36) (Edmonton, Alberta: Institute of Law Research and Reform, 1980) at 65. 
interest of the corporation. They took the position that a director must always be governed by the profit motive for shareholders ${ }^{247}$ ("shareholder primacy" conception), and is prohibited from taking into account the interests of employees, creditors, consumers, or society-at-large, unless it can be established that actions taken or payments made for non-business purposes would increase profitability. Moreover, a director is expected to pursue the profit motive for the equal benefit of all shareholders. Any other actions that may negatively influence shareholders wealth maximization are inadmissible, and may lead to breaches of the director's fiduciary duties.

More recently, however, courts have started to adhere to positions that deviate from shareholder profit maximization. For example, in Pente Investment Management Ltd. v. Schneider Corp, ${ }^{248}$ the committee accepted a bid from Smithfield Foods that was higher than market value of the shares of the company, but less than another bid which was made by Maple Leaf Foods Inc. The main issue of this case was whether the committee's actions were in the best interest of Schneider Corp or not. If not, the officers and directors of the corporation did not act in good faith. The Ontario Court of Appeal dismissed the action by Maple Leaf Foods, because after analyzing all the circumstances of the committee, the court came to the conclusion that the committee acted in the best interests of the company. It obtained fair value for the shareholders given the "intense time-limit-driven context",249 of the bid process.

\footnotetext{
${ }^{247}$ See, for example, Dodge v Ford Motor Company, supra note 48.

${ }^{248}$ Pente Investment Management Ltd v Schneider Corp, supra note 228.

${ }^{249}$ Robert E Milnes \& Kathleen M Ritchie, supra note 236 at 14.
} 
In a more recent case, Peoples Department Stores (Trustee of) $v$. Wise, ${ }^{250}$ the court gave an explanation regarding the issue of the best interests of the corporation:

It is clear that the phrase the "best interests of the corporation" should be read not simply as the "best interests of the shareholders." From an economic perspective, the "best interests of the corporation" means the maximization of the value of the corporation ... We accept as an accurate statement of law that in determining whether they are acting with a view to the best interests of the corporation it may be legitimate, given all the circumstances of a given case, for the board of directors to consider, inter alia, the interests of shareholders, employees, suppliers, creditors, consumers, governments and the environment. ${ }^{251}$

A similar position regarding the "best interests of the corporation" was expressed the case of BCE Inc. v. 1976 Debentureholders, ${ }^{252}$ : "in considering what is in the best interests of the corporation, directors may look to the interests of, inter alia, shareholders, employees, creditors, consumers, governments and the environment to inform their decisions" ${ }^{\prime 253}$. Moreover, the Supreme Court several times in this case referred to the fiduciary duty of a director "to act in the best interest of the corporation viewed as a good corporate citizen." ${ }^{, 254}$ It would seem that by this, the Supreme Court of Canada broadened

${ }^{250}$ Peoples Department Stores (Trustee of) v Wise, supra note 237.

${ }^{251}$ Ibid at para 42.

${ }^{252} B C E$, supra note 86 .

${ }^{253}$ Ibid at para 40.

${ }^{254}$ Ibid at para 66,81 . 
the scope of fiduciary duties, adding a new standard for assessing whether or not the fiduciary duty has been properly carried out ${ }^{255}$.

Whether the court supports the wealth maximization position, or that according to which a director should act in the best interest of all constituencies of a corporation, it is a fact that the interest of shareholders must be taken into consideration for the interests of both majority and minority shareholders.

Another element of the fiduciary duties of directors and officers is loyalty in the face of conflicts of interests. This duty includes many components, which were neatly summarized in the leading English case of Bristol and West Society v. Mothew ${ }^{256}$ by Millet L. J., who stated that it imposes on a director the duty to ${ }^{257}$ :

Act in good faith; he must not make a profit out of his trust; he must not place himself in a position where his duty and his interest may conflict; he may not act for his own benefit or the benefit of a third person without the informed consent of his principal. This is not intended to be an exhaustive list, but it is sufficient to indicate the nature of fiduciary obligations. They are the defining characteristics of the fiduciary ${ }^{258}$.

As can be seen, a director shall act in good faith and combine his/her own interests with the interests of the company he/she is working for. A director must also combine his/her interests in a way that is the best for the company. As fiduciaries,

\footnotetext{
${ }^{255}$ Sarah Bradley, BCE Inc, supra note 31 at 344-47.

${ }^{256}$ Bristol and West Building Society v Mothew, [1996] 4 All ER 698.

${ }^{257}$ Sarah Bradley, supra note 119 at 53.

${ }^{258}$ Bristol and West Building Society v Mothew, supra note 256 at 713.
} 
directors are under a duty to avoid any conflict between self-interest and the interest of the corporation.

Robert Milnes and Kathleen Richie observe that, "although recent legislation has developed statutory rules to regulate the director's duty to disclose his interest in a corporate transaction and to regulate his use of confidential information in insider trading, other breaches are generally left to be governed by the common law and each case must be considered on its particular facts" ${ }^{259}$. In Peso Silver Mines, ${ }^{260}$ for example, the Supreme Court of Canada held that the directors of the company were free to take up independently an opportunity originally offered to their corporation, but which had been rejected by the Board of directors in good faith on the basis that the corporation did not have sufficient funds to take up the opportunity. In finding for the directors, the court held there was insufficient evidence to show that the offer to the corporation "was accompanied by any confidential information unavailable to any prospective purchasers or that the directors had access to any such confidential information by reason of their office, ${ }^{261}$.

The position in Peso Silver Mines was changed in the leading Canadian case of Canadian Aero Services Ltd. v. O'Malley. ${ }^{262}$ There the Supreme Court of Canada held

${ }^{259}$ Robert E Milnes \& Kathleen M Ritchie, supra note 236 at 16.

${ }^{260}$ Peso Silver Mines Ltd v Cropper, [1966] SCR 673.

${ }^{261}$ Ibid at para 35.

${ }^{262}$ Canadian Aero Services Ltd v O'Malley, [1974] SCR 592. 
that former senior officers of a corporation were liable to the corporation when the officers deliberately set out to take advantage of a contract, the basis of which they had formerly developed as officers of the corporation. Justice Laskin held that senior officers have the same fiduciary duty to the corporation as its directors. This decision is important for several reasons. First, it is clear that each case must be considered in its own context and cannot be blindly conflated with other cases. Second, the principle from Peso Silver Mines that the directors of a corporation are always entitled to take advantage personally of opportunities formerly offered to their corporation, which were turned down for valid business reasons, was rejected. Finally, Justice Laskin made it clear that the fiduciary duties "extend past the time of employment." 263

Generally, the duty of loyalty and the duty to avoid conflicts of interest is hard to define, and each case has to be considered on its own facts. Nonetheless, it is clear that the directors and officers of a corporation are entitled to take advantage of business opportunities that have been formerly offered to their corporation but were turned down for valid business reasons after full and fair disclosure. But directors who intentionally misappropriate corporate opportunities for their own gain, and not for the corporation, will be liable to the corporation, even if the gain materializes after they have ceased to be directors.

${ }^{263}$ Robert E Milnes \& Kathleen M Ritchie, supra note 236 at 16. 
Both the $\mathrm{CBCA}^{264}$ and common law dealing with conflict of interest require directors and officers to disclose their interests in contracts and transactions. If a director or officer of a corporation fails to make the required disclosure, a court, on application by the corporation or any of its shareholders, may set aside the contract or transaction on any terms that it thinks fit, or require the director or officer to account to the corporation for any profit or gain realized on it, or do both of those things. ${ }^{265}$

Since the $19^{\text {th }}$ century, the courts have been strict about the rule that a contract of a corporation in which one of its directors had a personal interest, whether pecuniary or non-pecuniary, is "voidable at the option of the company, so that the company has a choice whether to affirm or avoid the contract, but the contract must be either totally affirmed or totally avoided and the right of avoidance will be lost if such time elapses or such events occur as to prevent rescission of the contract". ${ }^{266}$ Moreover, "the normal consequences which follow from a contract made by a person in such a fiduciary position is... [that] a director may be called on to account for profit which he has made out of the transaction" ${ }^{267}$. The only exception to this rule is when a director has fully declared

${ }^{264}$ CBCA, supra note 8, s 120.

${ }^{265} \mathrm{Ibid}$, s 120 (8).

${ }^{266}$ Hely-Hutchinson v Brayhead Ltd and Another [1967] 3 All ER 98 at 110. See also Luxembourg Ry Co v Magnay (No 2), (1858), 25 Beav 586 at pp 593, 594); Re Cape Breton Co ((1884), 26 Chd 221 at p 223, 228, 229, 234); Kaye v Croydon Tramways Co [1898] 1 Ch 358, 368; Transvaal Lands Co v New Belgium (Transvaal) Land and Development Co [1914-15] All ER Rep at pp 990, 991, [1914] 2 Ch at p 505), and Cook $v$ Deeks [1916-17] All ER Rep 285 at pp 290, 291, [1916] 1 AC 554 at pp 563, 564.

${ }^{267}$ Hely-Hutchinson v Brayhead Ltd and Another [1967] 3 All ER 98 at 107. 
his/her interest in some contract or transaction and received approval from shareholders. In that case, this contract generally cannot be rendered voidable.

These common law rules have had two main problems, which are now "removed" by modern statutes or amendments to existing ones. Firstly, it is common that when a director of a company is a controlling shareholder, he/she can escape liability by having the contract ratified by the shareholders' meeting where he/she has appropriate numbers of votes. Secondly, due to the strictness of the common law rule, a contract which was fair and in the best interest of a company was, in reality, not protected from voidability.

Realizing these problems, the Canadian legislator stipulated several provisions to solve the problems and to prevent a contract in which a director has interest from being voided. The CBCA tightened the disclosure requirements for directors and officers. Accordingly, a director or an officer of a corporation shall disclose to the corporation the nature and extent of any interest that he or she has in a material contract or material transaction, whether made or proposed, with the corporation ${ }^{268}$. As well, a director or officer must provide disclosure every time there is a material change in his/her interest regarding the transaction or contract. ${ }^{269}$ Furthermore, it is important to note that a director, who has interest in the contract or transaction, shall not vote on any resolution to approve this contract or transaction. ${ }^{270}$

${ }^{268}$ CBCA, supra note 8, s 120 (1).

${ }^{269}$ Ibid, s 120 (6).

${ }^{270}$ Ibid, s 120 (5). 
The CBCA also provides that the contract or transaction is not automatically voidable only because of the presence of a director's interest in the contract or transaction. ${ }^{271}$ Furthermore, the contract or transaction is not voidable if the interested director or officer was present or was counted to determine whether a quorum existed at the meeting of directors or committee of directors that considered the contract or transaction; if the interested director discloses his/her interest in accordance with the rules; the contract or transaction was approved by the board of directors or a shareholder meeting; and the contract or transaction was reasonable and fair to the corporation when it was approved or confirmed. ${ }^{272}$ The CBCA also provides for the situation when a director or officer does not disclose his/her interests and the transaction or contract was not reasonable and fair to the corporation. In this situation, a court may set aside the contract or transaction on any terms that it thinks fit, and require the director or officer to account for any profit and gain realized by him/her. ${ }^{273}$

Canadian statutes do not define what "material interest" means. However, cases provide some clarification. Concerning the term "material," the court in Exide Canada Inc. v. Hilts ${ }^{274}$ setting aside the contract and ordering the CEO to account for profits, stated that "a material interest includes a personal relationship with the person who was a party to a material contract. Even where a director had no monetary interest in a person,

\footnotetext{
${ }^{271}$ Ibid, s 120 (7).

${ }^{272}$ Ibid, s $120(7 ; 7.1)$.

${ }^{273}$ Ibid, s 120 (8).

${ }^{274}$ Exide Canada Inc v Hilts (2005), 11 BLR (4th) 311 (SCJ).
} 
but the negotiation involves a close personal friend of one of the directors, the transaction ought to be suspect." 275

Overall, the Canadian position regarding a director's interests is elaborate and well-considered. It provides the counter balance between directors, shareholders and the corporation itself. On the one hand, a director has to disclose all the important information, but on the other hand, if under some circumstances he/she does not do this, it does not mean that the transaction or contract will always be voidable, and that the director will be liable for that. This fiduciary duty requires that a director and officer shall disclose any personal interest he/she may have in a material contract or transaction involving the corporation. Moreover, directors and officers who permit a corporation to be a party to a material contract or transaction in which the director or officer has an interest must ensure that the contract is reasonable and fair to the corporation. If a director or officer adheres to these obligations, "it is unlikely that they can later be called upon to account to the corporation for the profits from a transaction. More importantly, the corporation will be unable to exercise its common law option to void the contract"276.

In summary, it can be said that the common law countries impose many more duties on directors and give them much more power than civil law countries do. Furthermore, the common law provides a good balance between the duties of directors and their liability, and also as to the relationship between directors and shareholders.

\footnotetext{
${ }^{275}$ Ibid at page 316 .

${ }^{276}$ Robert E Milnes \& Kathleen M Ritchie, supra note 236 at 19.
} 
Essentially, therefore, in all situations, a director's main duty is to act in the best interests of a corporation. That is why if a director is not satisfied with the action of the majority towards the minority or the company itself, he/she has the right not to implement the action or, more importantly, he/she can prevent its implementation. The director has an incentive to do so since if he/she carries out some action on the order of the majority shareholders, which action is not in the best interest of the corporation, or which oppresses the rights of some group, he/she will be personally liable for that action. Thus, a director in common law countries is a good means to balance the interests of the minority and majority shareholders of the company. In addition, a director in a common law country is disinterested in abusing the rights of shareholders because the costs for him/her may outweigh the benefits.

Altogether, so long as directors exercise their powers in accordance with law and articles, with diligence, and do not hide important information from shareholders, they are unlikely to be liable for the consequences, even if the consequences are negative for the company. It can be said that the common law imposes on the director one broad duty - to try to do everything to promote the interest of corporation - and if a director does all that depends on him/her, he/she will not be liable for the actions even if the results are not favorable. Business involves risks, and the common law only stipulates that a director shall make reasonable decisions not perfect ones. ${ }^{277}$ Of course, a director, as a human being, will make mistakes.

${ }^{277}$ Pente Investment Management Ltd v Schneider Corp, supra note 228. 
In sum, it should be pointed out that by borrowing from the fiduciary duties and other duties imposed on directors in common law countries, civil law may solve many of the problems that currently plague their corporate regulatory regimes.

\subsection{Derivative Action}

The separation of a legal entity from its shareholders is the main principle of corporate law, explicitly expressed in the famous Foss v. Harbotlle case. ${ }^{278}$ Because of this feature, the general rule is that only a company can be a complainant regarding its business affairs. In other words, a director, as a representative of a company, can bring a lawsuit on behalf and in the name of a company. Neither majority nor minority shareholders can bring an action to protect the interests of a company. However, it is common that management, using its power, may not act in the best interests of the corporation. As such, it is unlikely that a director will bring a lawsuit against him/herself.

Since Foss v. Harbottle, scholars and judges, have recognized that the general rule may raise problems where a director or managers own a controlling block of shares

in the corporation. ${ }^{279}$ Specific to this situation, the common law contrived several exceptions to this rule so that individuals could sue on behalf of a company. These exceptions thus allow derivative actions, enabling a shareholder to bring an action, for

\footnotetext{
${ }^{278}$ Foss v Harbotlle, (1843) 67 ER 189.

${ }^{279}$ Stepanie Ben-Ishai \& Poonam Puri, supra note 179 at 85.
} 
example, if directors or officers act in an "ultra vires" manner, ${ }^{280}$ or if directors or officers holding the majority of shares use their shares to approve fraud or a breach of fiduciary duty committed against the company by themselves or their associates. ${ }^{281}$ The Dickerson Committee pursued the same position ${ }^{282}$ when it indicated that the "typical examples of cases where a derivative action may be invoked are actions against directors or officers for a breach of duty under s. 9.19 [now s. 122 of the CBCA] alleging self-dealing or negligence, an action for an injunction to preclude a threatened injury to a corporation, or an action to restrain an act outside the scope of the authority of the corporation, its directors or officers. ${ }^{.283}$

It is most important to keep in mind that the derivative action relates only to the enforcement of the rights of the corporation. "It is not available as a remedy to enforce the rights of an individual shareholder or even a group of shareholders, although a group of shareholders may bring, in representative form, a derivative action in the name of the corporation if they can characterize the issue as the enforcement of a right of the corporation. ${ }^{284}$ ${ }^{280}$ Edwards $v$ Halliwell, supra note 181; Simpson v Westminster Hotel Co, supra
note 178.

${ }^{281}$ Stepanie Ben-Ishai \& Poonam Puri, supra note 179 at 86.

${ }^{282}$ Dickerson Report, supra note 233.

${ }^{283}$ Ibid at 160.

${ }^{284}$ Ibid. 
Modern Ukrainian corporate law is not familiar with the concept of a derivative suit. As was mentioned in the previous Chapter, in Ukraine only the majority can, theoretically, induce a company to bring a lawsuit against management. In the situation that a director is an "executor" of the majority's will, the minority shareholders' rights can be abused, without the possibility that they can bring an action on behalf of the company. In other words, minority shareholders cannot protect their interest by using this remedy in Ukraine.

In Germany, this remedy is more fully developed than in Ukraine. A German $\mathrm{GmbH}$ is also a separate legal entity. As such, it is prohibited for individual shareholders' rights to be enforced against $\mathrm{GmbH}$ organs - that is, German law does not allow an individual shareholder to compel the company's organs to act in accordance with their duties. In the $\mathrm{GmbH}$, the shareholder right to bring a lawsuit on behalf of the corporation (actio pro societate) is stipulated under certain conditions. According to Article 46 (8) of the Private Limited Companies Act ${ }^{285}$ shareholders, in the meeting, can decide whether to bring an action against directors or shareholders for damage that they did to the company or not. The general rule is that this resolution can only be passed by the majority. But since, the majority owe a duty of loyalty, an individual shareholder may bring a lawsuit in the case that the majority refuse to pass a resolution regarding bringing an action against shareholders or a director, thereby breaching the fiduciary duty.

${ }^{285}$ The Private Limited Companies Act, supra note 107, Paragraph 46 (8). 
Obviously, in German law, there is no statutory basis for derivative suits regarding a $\mathrm{GmbH}$, although the possibility is generally recognized by scholars, and, most importantly, by courts. However, in both Germany and Ukraine, many scholars consider that the shareholders' option to bring a lawsuit against directors, who act dishonestly, is nearly impossible to act upon ${ }^{286}$.

In the $\mathrm{CBCA}$ this remedy is stipulated in Article 239 under "commencing derivative action". It is pointed out that the "statutory derivative action provisions replace the common law rules governing derivative actions, both as to availability of such relief and the procedure to be followed" 287 . In other words, the statutory derivative action provisions not only "expanded the availability of derivative action relief, compared to its availability in equity", ${ }^{288}$ but also "introduced more precise procedural and substantive requirements that must be satisfied before such relief will become available" 289 .

In the CBCA, the derivative action is foreseen in Section 239. It reads: "a complainant may apply to a court for leave to bring an action in the name and on behalf of a corporation or any of its subsidiaries, or intervene in an action to which any such body corporate is a party, for the purpose of prosecuting, defending or discontinuing the

${ }^{286}$ Reinier Kraakman et al, The Anatomy of Corporate Law: A Comparative and Functional Approach (New York: Oxford University Press, 2004) at 128.

${ }^{287}$ Kevin P McGuinness, supra note 124 at 1340.

${ }^{288}$ Ibid at 1242 .

${ }^{289}$ Ibid at 1340 . 
action on behalf of the body corporate" ${ }^{\prime 290}$. Because a complainant in this remedy brings a lawsuit on behalf of a corporation, some scholars call it the "statutory representative action"291.

Canadian law provides for the possibility to bring a derivative action for large numbers of stakeholders. Pursuant to Section 238, the notion of a "complainant" denotes a registered holder or beneficial owner, or a former registered holder or beneficial owner of the security of a corporation or any of its affiliates, a director, an officer or a former director or officer of a corporation or any of its affiliates, the Director, or any other person who, in the discretion of a court, is a proper person to make an application under the remedy. It is clear that shareholders, whether they are majority or minority, are proper complainants and are able to bring a derivative action.

Canadian law addresses how not to upset the balance of power between the minority and majority/directors. To prevent the minority from abusing (misusing) the right to bring a lawsuit, the $\mathrm{CBCA}$ specifies three conditions which shall precede the action. The first condition is to give notice to the directors of the corporation or its subsidiary of the complainant's intention to apply to the court under Section 239 of the CBCA not less than fourteen days before bringing the application, or as otherwise ordered by the court, if the directors of the corporation or its subsidiary do not bring,

${ }^{290}$ CBCA, supra note 8, s 239 (1).

${ }^{291}$ Bruce Welling, Corporate Law in Canada: the Governing Principles, 3rd ed (Mudgeeraba, Australia; London ON: Scribblers Publishing, 2006) at 509. 
diligently prosecute, or defend or discontinue the action. ${ }^{292}$ This condition "reflects the concept of exhausting intra corporate remedies, with view to advocating the pursuit of a solution first within the corporation so as to economize judicial resources and to prevent a minority shareholder from abusing its right., ${ }^{, 293}$

The second condition foresees that the complainant has to act in good faith. ${ }^{294}$ The last, third condition, stipulates that the derivative action should be in the interests of the corporation or its subsidiary and that the action be brought, prosecuted, defended or discontinued. ${ }^{295}$ The last two conditions are interconnected and supplement each other. By the notion "to act in good faith", Canadian law seeks to "preclude private vendetta" ${ }^{296}$ and "by requiring the complainant to establish that the action is "prima facie in the interest of the corporation", it blocks actions to recover small amounts, particularly actions really instituted to harass or to embarrass directors or officers who have

${ }^{292}$ CBCA, supra note 8, s 239 (2) (a).

${ }^{293}$ Jianfeng Ji, supra note 132 at 119.

${ }^{294}$ CBCA, supra note 8, s 239 (2) (b).

${ }^{295}$ Ibid, s 239 (2) (c).

${ }^{296}$ Dickerson Report, supra note 233 at 161. 
committed an act which, although unwise, is not material."297 This position has also been supported by the judiciary. For example, in Winfield v. Daniel, ${ }^{298}$ the court held that:

Good faith is said to exist where there is prima facie evidence that the complainant is acting with proper motives such as reasonable belief in the merits of the claim. Good faith is a question of fact to be determined on the facts of each case. The typical approach by the Courts is not to attempt to define good faith but rather to analyze each set of facts for the existence of bad faith on the part of the applicant. If bad faith is found, then the requirement of good faith has not been met. ${ }^{299}$

Concerning the last condition, the complainant has to make it clear to a court that the claim is in the interest of the company or its subsidiary, but not in his/her own interest. ${ }^{300}$ In other words, if, for instance, minority shareholders bring a lawsuit for their own interests and not for the corporation, they would not fulfill the third condition and, thus, the court must dismiss the application invoking the derivative action. It is also extremely important that the $\mathrm{CBCA}$ allows for complainants to show prima facie evidence that some action was not in the best interest of the corporation. This is significant in light of the minority shareholder's weak position to provide information in support of their claim.

297 Ibid.

${ }^{298}$ Winfield v Daniel, 2004 CLB 12084, 21 Alta LR (4th) 337, [2004] AJ № 37, 2004 ABQB 40.

${ }^{299}$ Ibid at para 16.

${ }^{300}$ P M Vasudev, Stakeholders in the CBCA: An Appraisal and Some Proposals, online: Social Science Research Network $<$ http://www.ssrn.com $>$. 
Analyzing the CBCA and court decisions, it is possible to come to the conclusion that these three conditions are compulsory. Thus, not showing even one of them will make it impossible to bring an action. Moreover, all three must be shown or proven by the complainant, which means that the complainant bears the burden of proof ${ }^{301}$.

Concerning a court's power in connection with derivative action in Canada, the CBCA explicitly provides that "the court may at any time make any order it thinks fit including, without limiting the generality of the foregoing, an order authorizing the complainant or any other person to control the conduct of the action; an order giving directions for the conduct of the action; an order directing that any amount adjudged payable by a defendant in the action shall be paid, in whole or in part, directly to former and present security holders of the corporation or its subsidiary instead of to the corporation or its subsidiary; and an order requiring the corporation or its subsidiary to pay reasonable legal fees incurred by the complainant in connection with the action."302 Clearly, a court is not limited in its power to resolve a dispute involving derivative actions.

Derivative action is an extremely important right or remedy for a minority shareholder. It provides one of only a few possible ways that the minority can protect him/herself and a corporation from managers and majority shareholders, that is, to resist or oppose the deficiency of corporate personality and majority rules. Derivative action

${ }^{301}$ See, for example, Tremblett $v$ SCB Fisheries, Ltd (1993), 116 Nfld \& PEIR 139 (Nfld SC) at para 58; Jerry v Gillard, [2005] AJ № 104 (QL) (QB) at para 11,12.

${ }^{302}$ CBCA, supra note 8, s 240. 
also prevents directors from abusing their right, and forces management to act in the best interest of a corporation, rather than merely in its own interest or the interest of the majority. Bruce Welling calls it a "statutory representative action" and describes it as "the minority shareholder's sword to the majority's twin shields of corporate personality and majority rule." ${ }^{303}$ Thus, it will be very useful to implement such a remedy in the civil law countries. As well, those of them, like Germany, that have something similar to derivative action, should pay attention to the use of this remedy from the common law perspective. Basically, derivative action, which is outlined in the CBCA, should be an example to emulate for civil law countries. Moreover, the right to bring a derivative action has to be explicitly stipulated in statutes. The statute must foresee the possibility for the plaintiff to bring a derivative action if several conditions are met. First, a complainant should be a shareholder, regardless of the number of shares he or she holds. Second, the director must be notified before a derivative action is brought. Third, a director should act in good faith and in the best interest of the corporation.

To increase the chances of using such a remedy, civil law statutes must clearly specify that a complainant is not required to give security for costs in any application made or action brought under the derivative action. Furthermore, the interim costs can be paid to the complainant by a corporation, if a court order to do this. Adopted in this way, this will make it likely to protect minority shareholders against the majority and management, and maintain a balance between them.

${ }^{303}$ Bruce Welling, supra note 290 at 509; Jianfeng Ji, supra note 132 at 121. 


\subsection{Oppression Remedy}

One of the most powerful weapons for the protection of the rights and interests of minority shareholders in Canada is the oppression remedy. If an act or omission is carried out in a manner that is oppressive or unfairly prejudicial to, or if it unfairly disregards the interests of any security holder, creditor, director or officer, the court may make an order to rectify the matter. ${ }^{304}$ The oppression remedy is "the broadest, most comprehensive and most open-ended shareholder remedy in the common law world" ${ }^{305}$ It is hard to disagree with this view.

Many judges have tried to define "oppressive," "unfairly prejudicial" and "unfairly disregards." But in the end, it all comes down to one major question: "Is the

conduct unfair to the shareholder?" ${ }^{306}$ In other words, the general ground for bringing an action under s.241 CBCA is "unfairness". Thus "fairness" or "unfairness" is the "main" standard by which judges decide the presence or absence of oppression. This position was confirmed in Westfair $v$ Watt ${ }^{307}$ : "I see no significant difference between the grounds in s.

${ }^{304}$ CBCA, supra note 8, s 241(2).

${ }^{305}$ Stanley Beck, "Minority Shareholders' Rights in the 1980, Special Lectures of the Law Society of Upper Canada, Corporate Law in the 1980s (Don Mills, Ont.: R De Boo, 1982) at 311.

${ }^{306}$ First Edmonton place ltd v 315888 Alberta Ltd, [1988] AJ no 511 (QL) at para 27 [First Edmonton].

${ }^{307}$ Westfair Food Ltd v Watt (1991), 26 ACWS (3d) 361 [Westfair Food]. 
241. They are identical and duplicative, and this superfluity is not an aid to interpretation"

However, "fairness" is also a very subjective, broad and ambiguous notion. That is why Canadian courts and scholars come up with the concept of "reasonable expectation," 309 according to which the presence or absence of oppression is now assessed in Canada. In Ebrahimi v. Westbourne Galleries Ltd, ${ }^{310}$ Lord Wilberforce expressed this significant principle thus "[a] limited company is more than a mere judicial entity, with a personality in law of its own: that there is room in company law for recognition of the fact that behind it, or amongst it, there are individuals, with rights, expectations and obligations inter se which are not necessarily submerged in the company structure" 311 . The prevalence of the "reasonable expectation" principle has been supported by the Stephanie Ben-Ishai and Poonam Puri in their paper, ${ }^{312}$ - where they write that an "important result of the judicial application of the oppression remedy has been the

\footnotetext{
${ }^{308}$ Westfair Food, ibid at para 13.

${ }^{309}$ Naneff v Con-Crete Holding Ltd (1995), 23 OR (3d) 481 at para 28.
}

The law is clear that when determining whether there has been oppression of a minority shareholder, the court must determine what the reasonable expectations of that person were according to the arrangements which existed between the principals. See also 820099 Ontario Inc v Harold E Ballard Ltd (1991), 3 BLR (2d) 113 at para 123 (Ont Gen Div).

${ }^{310}$ Ebrahimi v Westbourne Gallereies Ltd, [1972] 2 All ER 492.

${ }^{311}$ Ibid at 500.

${ }^{312}$ Stepanie Ben-Ishai \& Poonam Puri, supra note 179. 
development of a test of reasonable expectation of shareholders, which must be taken into account by the management and other shareholders" 313 .

This new approach enlarged the chances for an oppressed person to protect himself or herself. Moreover, it is significant that "reasonable expectation" encompasses situations that do not violate strict legal principles, but are inconsistent with the reasonable expectations of the parties. ${ }^{314}$ In other words, the applicant is able to bring a claim even if the action of the director or majority is lawful, but unfair ${ }^{315}$. This remedy is focused "on concepts of fairness and equity rather than on legal rights."316

In the recent BCE Inc. v. 1976 Debentureholders case, the Supreme Court of Canada summarized the Canadian position regarding using the oppression remedy and gave understandable conduct recommendations on employing it. The court clearly said that it is impossible to "catalogue exhaustively situations where a reasonable expectation may arise due to their fact-specific nature" ${ }^{\text {317 }}$. However, the Supreme Court pointed out that some factors should be taken into account when considering the existence or absence of reasonable expectation. They include general commercial practice, the nature of the

\section{${ }^{313}$ Ibid at 107.}

${ }^{314}$ Ibid at 89.

${ }^{315}$ BCE, supra note 84 at para 71: "Actual unlawfulness is not required to invoke s $241 \%$.

$$
\begin{aligned}
& { }^{316} \text { Ibid. } \\
& { }^{317} \text { Ibid at para } 70 .
\end{aligned}
$$


corporation, the relationship between the parties, past practice, steps the claimant could have taken to protect itself, representations and agreements and the fair resolution of conflicting interests between corporate stakeholders. ${ }^{318}$

It is important to note that supporting only the reasonable expectation requirement in an oppression claim is not enough. It means that not all conduct that is harmful to a shareholder will automatically give rise to the possibility of seeking the oppression remedy. The complainant has to show that the reasonable expectation was violated by the conduct falling within the term "oppression," "unfair prejudice" or "unfair disregard" of a relevant interest. In more detail, the Supreme Court of Canada held:

The reasonable expectations analysis that is the theoretical foundation of the oppression remedy, and the particular types of conduct described in s. 241, may be seen as complementary, rather than representing alternative approaches to the oppression remedy, as has sometimes been supposed. Together, they offer a complete picture of conduct that is unjust and inequitable, to return to the language of Ebrahimi. ${ }^{319}$

The original wrong recognized in the cases was described simply as oppression. This notion is generally associated with conduct that has been described in different manners, such as "burdensome, harsh and wrongful" 320 , "a visible departure from

${ }^{318}$ Ibid at para 72.

${ }^{319}$ Ibid at para 89.

${ }^{320}$ Scottish Co-operative Society v Meyer, [1959] AC 324 at 341; Redkop v Robco Construction Ltd (1978) 89 DLR (3d) 507, 5 BLR 58 (BCSC). 
standards of fair dealing," 321 or "abuse of power",322. It is wrongs of such nature that gave the remedy its name and which is now generally used to cover all claims under s.241. However, this term also stipulates a particular type of injury, which is a wrong of the most serious sort. ${ }^{323}$

Regarding the term "unfair prejudice" the courts expressed the following position:

"unfair prejudice" is generally seen as involving conduct less offensive than "oppression". Examples include squeezing out a minority shareholder, failing to disclose related party transactions, changing corporate structure to drastically alter debt ratios, adopting a "poison pill" to prevent a takeover bid, paying dividends without a formal declaration, preferring some shareholders with management fees and paying directors' fees higher than the industry norm. ${ }^{324}$

Consequently, the Supreme Court of Canada held that ""unfair disregard" is viewed as the least serious of the three injuries, or wrongs, mentioned in s. 241 . Examples include favoring a director by failing to properly prosecute claims, improperly reducing a shareholder's dividend, or failing to deliver property belonging to the claimant". 325

${ }^{321}$ Fiorillo v Krispy Kreme Doughnuts, Inc, [2009] OJ No 2430, 60 BLR (4th) 113 at para 157.

${ }^{322}$ McAteer v Devoncroft Developments Ltd, [2001] AJ No1481, 2001 ABQB 917 at para 415 .

${ }^{323}$ BCE, supra note 86 at para 92.

${ }^{324}$ Ibid at para 93.

${ }^{325}$ Ibid at para 94. 
It is important to note the fact that CBCA provides the possibility of bringing an oppression claim to a variety of applicants. Pursuant to Section 238, the term "complainant" means a registered holder or beneficial owner, or a former registered holder or beneficial owner, of a security of a corporation or any of its affiliates, a director or an officer or a former director or officer of a corporation or any of its affiliates, the Director, or any other person who, in the discretion of a court, is a proper person to make an application under the remedy. It is clear that shareholders, whether majority or minority, are proper complainants to bring an application against oppression.

It is also significant that the major difference between derivative action and the oppression remedy is that in a derivative action, the complainant seeks the best interests of the corporation and does not pursue any personal interest or the interest of a specific group. In contrast, the oppression remedy is initiated by a person or a group of persons pursuing a personal interest in the corporation and trying to get a personal benefit from the action ${ }^{326}$. This is one of the major reasons the oppression remedy is less complicated in its application, because to prove that an alleged interest is in the best interest of the corporation is very complicated.

As with derivative action, in an application against oppression, the court is authorized to "make any interim or final order it thinks fit." ${ }^{\text {, } 27}$ However, the breadth of a court's broad discretion is restricted in some ways. First, a court shall apply the "general

\footnotetext{
${ }^{326}$ P M Vasudev, supra note 299 at 7.

${ }^{327}$ CBCA, supra note 8, s.241 (3).
} 
principle of equity"328. This is supported by the Dickerson Committee which proposed that "the courts should have very broad discretion, applying general standards of fairness, to decide these cases on their merits" ${ }^{\$ 29}$. The second restriction is that the court shall use its power to correct or rectify the situation. Thus, in Naneff $v$. Con-Crete Holding Ltd, ${ }^{330}$ in which the court held that "broad as that discretion is, however, it can only be exercised for a very specific purpose; that is, to rectify the oppression." ${ }^{331}$ An even more demonstrative assertion is found in the case 820099 Ontario Inc. v. Harold E. Ballard Ltd., where the Ontario Court of Justice held:

The court should not interfere with the affairs of a corporation lightly. I think that where relief is justified to correct an oppressive type of situation, the surgery should be done with a scalpel, and not a battle axe. I would think that this principle would hold true even if the past conduct of the oppressor were found to be scandalous. The job for the court is to even up the balance, not tip it in favour of the hurt party ${ }^{332}$.

Clearly, Canadian scholars and judiciary have evolved a mechanism to prevent abuse from the broad power of a court, by stating that the court has to rectify the dispute.

Seen as mainly contrived to protect minority shareholders in a closely-held corporation, this remedy solves their financial predicament as a complainant is not

${ }^{328}$ Kevin McGuinness, supra note 124 at 1252.

${ }^{329}$ Dickerson Report, supra note 233 at 162

${ }^{330}$ Naneff v Con-Crete Holding Ltd, supra note 308.

${ }^{331}$ Ibid at para 22.

332820099 Ontario Inc v Harold E Ballard Ltd, [1991] OJ No 266, 25 ACWS (3d) 853, 1991 CarswellOnt 142 at para 36. 
required to give security for costs in any application made or action brought, or intervention under this remedy. ${ }^{333}$ Furthermore, the court can at any time order the corporation or its subsidiary to pay to the complainant interim costs, including legal fees and disbursements.

Nowadays, the oppression remedy is one of the best means to protect the interest of minority shareholders in Canada. The empirical study of Stephanie Ben-Ishai and Poonam Puri concluded that this remedy is preferred by most shareholders, compared with other remedies, for the purpose of benefitting minority shareholders in closely-held corporations. The cases also show that in Canada minority shareholders prefer to use the oppression remedy, rather than derivative action. This may be on account of the broad scope of the oppression remedy, and the idea that it does not have a strong connection to the directors' fiduciary duties, making it easier to prove in court. In other words, shareholders are more motivated to use the oppression remedy because, according to statistics, they have better chances of winning these cases. They may also prefer to use it because it does not necessarily require showing a breach of law or rights, as this remedy provides that shareholders can make an application against oppression also in the situation where there is no breach of law, but this action contradicts or breaks the complainant's reasonable expectation. Finally, shareholders prefer to use the oppression remedy because it protects their own interests and not the company's. Reimbursement will not go to the company, but to them.

${ }^{333}$ CBCA, supra note 8, s 242 (3). 
Ukraine and Germany are not familiar with the oppression remedy. On this score, it is significant to note that many problems in corporate administration, which cannot be solved, or can hardly be solved in civil law countries can, theoretically and practically, be resolved for the benefit of shareholders and a corporation itself in common law countries by using the oppression remedy. Examples include squeezing out a minority shareholder, failing to disclose related party transactions, changing the corporate structure to drastically alter debt ratios, adopting a "poison pill" to prevent a takeover bid, paying dividends without a formal declaration, preferring some shareholders with management fees and paying directors' fees higher than the industry norm, failing to properly prosecute claims, improperly reducing a shareholder's dividend or distribution of all the profit as salaries for majority shareholders, hiring the majority's relatives or trusted persons to receive "kickback," or failing to deliver property belonging to the claimant. This is not a full list of examples where the minority can successfully protect his/her interest. Corporate law is developing very fast, thus the "broad remedy" that can be employed in many situations is the key to protect oppressed parties and improve the attractiveness of conducting of business, which will positively reflect on the stakeholders and society. Indeed, the significance of the remedy, is captured in the following words:

[B] eyond question, [the oppression remedy is] the broadest, most comprehensive and most open-ended shareholder remedy in the common law world. It is unprecedented in its scope. It is being applied to a wide variety of situations in both public and private companies, and, most importantly, the courts have shown a willingness to carry out the mandate 
that the legislatures have given them to fashion remedies for shareholders who complain that they have been dealt with unfairly. ${ }^{334}$

\subsection{Cumulative Voting}

As already mentioned, a cumulative voting mechanism provides the possibility to elect, at least, one "minority director." Furthermore, this is the only way for the minority to participate in the management of the company because, in this situation, a director who is elected by the minority will, at least, take into consideration the interests of the minority. Many countries assume cumulative voting as a compulsory type of voting when electing directors; usually they are the countries with robust minority shareholder's protection policy. Others do not provide compulsory cumulative voting, however do not prohibit this kind of voting. ${ }^{335}$ In countries where cumulative voting is not compulsory in the case of the election of directors, it is unlikely that the majority will include it in the articles of association. Power sharing is rarely accepted, and this is a major reason not to include cumulative voting in the articles.

As Kevin McGuiness explains, "Cumulative voting is a system of voting under which each elector has a number of votes determined by reference to the number of officers that are to be filled by election, with the elector being free to distribute those votes among such number of persons or concentrate those votes on any one person, as the elector may see fit" 336 . Under cumulative voting, "each shareholder is entitled to vote at

\footnotetext{
${ }^{334}$ Stanley Beck, supra note 204 at 311.

${ }^{335}$ For example, Ukraine, Germany and Canada.

${ }^{336}$ Kevin P McGuiness, supra note 124 at 771.
} 
an election of directors, has the right to cast a number of votes equal to the number of votes attached to the shares held by the shareholder multiplied by the number of directors to be elected, and may cast all of those votes in favor of one candidate or distribute them among the candidates in any manner.",337

This procedure works in the following way. Shareholders have to elect 3 directors, for example. The first shareholder has 100 votes, the second 50 and the third 25 respectively. Under simple majority voting, the shareholder who has 100 votes will elect all directors, because he/she has more shares than the other two together and his/her votes constitute more than 50 per cent. Employing cumulative voting, however, the minority could elect, at least, one director. In our case, according to cumulative voting, the first shareholder has 300 votes, the second 150 votes, and the third 75 votes (number of votes multiplied by the number of directors to be elected). If the second and third cast all of their votes in favor of one director, this candidate will likely become a director. Thus, it is apparent in this example that with the same conditions (the same number of shareholders and appointed directors), the result can be totally different depending on the kind of voting adopted.

Based on the above, it is reasonable to propose that regarding the procedure of election of directors, cumulative voting should be compulsory, unless otherwise stipulated in the unanimous shareholders agreement, or as passed by a special resolution of the $3 / 4$ majority. This provision will prevent the majority from abusing minority shareholders and create some balance between the minority and the majority, though the

${ }^{337}$ CBCA, supra note 8, s 107 (b). 
majority will still prevail in decisions regarding the affairs of the company. Employing compulsory cumulative voting will maintain the prevailing interest and status of the majority and "Majority Rules," but it will give the minority the chance to elect a "right director" who, likely, will support their positions. Moreover, this director will be a minority's "watchdog" and will control the majority and other directors.

This kind of voting cannot solve all the problems that arise in corporate relationships, but it can at least increase the chances for minority shareholders to participate in the management of the corporation and, consequently, enhance the protection of minority rights.

\subsection{Obstacles to Implementing Common Law Remedies in a Civil Law}

\section{System}

The recommendations to implement some remedies from common law countries in civil law countries, such as Germany and Ukraine, will not be complete without analyzing obstacles which can arise in regard to their adoption. Unfortunately, there is a shortage of literature regarding these issues; as such, the views put across in this part mainly reflect the author's analysis. It is common knowledge that common law and civil law systems have many similarities and differences. Consequently, some institutions, remedies and procedures which perfectly fit and work in one system, can be useless or unviable in the other system. A good example is trust. In the common law world, this institution is widely used and, theoretically, could adapt very well. However, in the 
continental world, many countries have tried to create something similar to trust, but it either does not work at all, or it does not work in the same manner as in common law countries. For example, Germany, Ukraine and France do not stipulate the trust as a corporation, but foresee the possibility to create fiduciary management in regard to this on the basis of contract, not a corporation. ${ }^{338}$ However, because the civil law does not foresee split property, this institution cannot work for reason of the security of assets. This is because the settler remains an owner. In the case of bankruptcy, seizure of the property transferred into a fiduciary management upon the claim of the management settler's creditor is allowed, the property management agreement is terminated, and the property is included in the bankruptcy estate ${ }^{339}$. Again, the trust does not work in most civil law countries in the case of inheritance, because of the civil law's conception of private property. The only civil law country that has largely adopted Anglo-Saxon trust legislation is Liechtenstein. However, being a civil law jurisdiction, trust assets are vulnerable to forced heirship provisions, although there are time limitations on such claims. ${ }^{340}$ In light of these examples, it is necessary to consider whether it is possible to adopt the above-mentioned remedies in the civil law countries to protect minority shareholders.

${ }^{338}$ See for example, Civil Code of Ukraine, supra note 98, Article 1029, 316.

${ }^{339}$ Ibid, Article 1040.

340 Tax Jurisdictions, Liechtenstein: Types of Company, online: LOWTAX: Global Tax \& Business Portal <http://www.lowtax.net/lowtax/html/jlicos.html\#trust>. 
As Alan Watson has noted, while "[t]he act of borrowing is usually simple ... build[ing] up a theory of borrowing, on the other hand, seems to be an extremely complex matter." ${ }^{341}$ It is complex because to be crowned with success, ${ }^{342}$ an imported rule should fit into its new environment at the micro and macro levels. Micro-fit means "how well the imported rule complements the preexisting legal infrastructure in the host country." ${ }^{343}$ Macro-fit is "how well the imported rule complements the preexisting institutions of political economy in the host country." 344 The success or failure of legal adoption (transplant) varies over time and largely depends on the degree to which the adoption (transplant) "fits the prevailing legal and non-legal infrastructure of which it is a part. ${ }^{, 345}$ The more it fits, the more chances that the imported rule, principle or institution will work in the host country as it works in the donor country.

The first institution that may be usefully implemented in legislation is cumulative voting. There are no serious theoretical, conceptual, practical and financial obstacles to adopting this kind of voting. This institution fits on both the micro and macro levels in

${ }^{341}$ Alan Watson, “Aspects of Reception of Law” (1996) 44 Am J Comp L 335 at 335.

${ }^{342}$ In this case, success simply means using the imported legal rule in the same way that it is used in the home (donor) country.

${ }^{343}$ Hedeki Kanda \& Curtis J Milhaupt, Re-examining Legal Transplants: The Director's Fiduciary Duty in Japanese Corporate Law, online: Social Science Research Network <http://www.ssrn.com> at 9.

344 Ibid.

${ }^{345}$ Ibid at 21. 
any new jurisdiction of corporate governance and management regulation. Moreover, as mentioned in previous chapters, cumulative voting is not prohibited in the majority ${ }^{346}$ of civil law countries, hence it can be easily implemented into legislation. Indeed, to protect the minority shareholder by giving him/her a more viable opportunity to elect, at least, some director, a government must change legislation and endorse compulsory cumulative voting for electing directors.

Concerning derivative action, to adopt such a remedy will not contradict existing civil law theory. More importantly, it can easily be used in practice. This remedy could bring some balance among the weight of interests of the minority, majority and the corporation itself. Furthermore, this remedy is also based on common sense: if a majority with a director does not act in the best interests of a corporation, there is no reason why the minority should be unable to bring a lawsuit. Implementation of derivative action will also not upset the balance of power between the majority and minority. It means that if a minority does not act in good faith, civil law theory accommodates counter-claim, which will serve as a safeguard against abuse of the power to bring a derivative action. Thus, stipulating derivative action in legislation will be enough to implement this remedy and increase minority shareholder protection. However, implementation should be systemic. First of all, legislation must explicitly say that in the case of a derivative action, shareholders

${ }^{346}$ Possibly, not all civil law countries allow cumulative voting, However, from their legislations, Ukraine, Russia, Belorussia, Germany, France, Italy, Liechtenstein, Switzerland do not prohibit cumulative voting. 
act as representatives of a corporation and not as complainants ${ }^{347}$. This is because class (collective) lawsuits are not recognized in most civil law countries. Moreover, according to Ukrainian law, for example, a person who acts on behalf of someone and in the interests of someone is a representative. Thus, the civil law countries recognize only one complainant. There cannot be more than one complainant according to civil law court procedures. It is possible to bring a lawsuit against many respondents, but not by many complainants. In this case, a complainant should be a corporation, because this remedy is devised primarily to protect the interests of a corporation. Second, statutes must stipulate that interim costs should be reimbursed to shareholders by the corporation. Again, this is because this action is in the interests of a corporation, and shareholders are only representatives. Finally, the statute must foresee the possibility for shareholders to bring a derivative action if several conditions are met. First, the director must be notified before a derivative action is brought. Second, a shareholder should act in good faith and in the best interest of the corporation.

The implementation of the common law director's duties, the duty of care and fiduciary duties, and oppression remedy in civil law legislation, is more complex. It requires making deliberate decisions and taking gradual steps. It is not enough just to "put" (stipulate) some provision regarding director duties and the oppression remedy in the legislation. Such a provision will not work for the following reasons. First, the

${ }^{347}$ See for example, Rostislav Sergeyevich Kravchenko, Ensuring and Protecting Shareholders' Rights to Information in the Process of Corporate Management (Candidate of Legal Science Thesis, Moscow State Institute of International Relations (MGIMO University), 2001) at 144 [translated by author]. 
common law director's duties have a centuries-old history of development and, most importantly, utilization. Second, the duties, and the oppression remedy were developed, and are still being developed mainly by the judiciary. As generally known, courts in civil law countries have less power; they cannot interpret laws, and their decisions do not have binding force for other parties. Third, the oppression remedy in common law countries encompasses situations that do not violate strict legal principles, but are inconsistent with the reasonable expectations of the parties ${ }^{348}$. In other words, the applicant is able to bring a claim even if the action of the director or majority is lawful, but unfair ${ }^{349}$. This position is inadmissible in a civil law world. Continental law has several basic principles which a previous sentence breaches. In civil law countries, the main principle in private law, to which the regime of corporate law belongs, is that a person can do everything not prohibited by the law ${ }^{350}$. Consequently, if an action is not prohibited, everyone can perform it. The second principle, which flows from the first one, provides that a person can seek help in court only if his/her right is violated. If the action is not prohibited (first principle), then it is lawful and, consequently, the action cannot breach someone's right (second principle), and so a person does not have a right to apply to court. Another general rule is that a person can only be liable if there is evidence that can confirm the guilt, damage and cause-effect relationship in issue. Guilt is required to prove breach of

${ }^{348}$ Stepanie Ben-Ishai \& Poonam Puri, supra note 179 at 89.

${ }^{349}$ See for example, BCE, supra note 86 at para 71: "Actual unlawfulness is not required to invoke s 241 ".

${ }^{350}$ See for example, D V Bobrova, O V Dzera, Civil Law of Ukraine: Textbook: 2 volumes (Kyiv: Jurincom Inter, 1999) [translated by author]. 
some rules (laws). Thus, the general rule regarding the liability of a person also contradicts adoption of the principle of "reasonable expectation" in the oppression remedy. Fourth, the power of the court must be explicitly defined in a civil law system because of the principle of public law which allows exercising only powers specified in $\operatorname{law}^{351}$. In other words, statutes have to provide the full list of powers with which the court is vested. Hence, the formulation of the power of a court to "make any order it thinks fit ${ }^{\prime 352}$ is, to say the least, incorrect in a civil law system and cannot be used in this manner.

In the case of fiduciary duties, it can be asserted that, theoretically and practically, they can be implemented in civil law countries, though not easily. Indeed, a lot of work must precede the transplantation of the duties into civil law. The experience of Asian countries, such as Japan and Taiwan (China), can serve as instructive examples of how to implement the common law institutions in civil law countries, and which mistakes not to repeat. Both of these countries, by and large, "inherited the German law tradition" "353. As such, their legal systems have many features similar to those of Germany and Ukraine.

${ }^{351}$ See for example, Constitution of Ukraine, supra note , Article 19: Public authorities and bodies of local self-government and their officials shall be obliged to act only on the grounds, within the powers, and in the way determined by the Constitution and the laws of Ukraine.

${ }^{352}$ CBCA, supra note 8, s 240.

353 Christopher Chen Chao-hung, Transplantation of Duties into Civil Law Jurisdiction: Experiences from Taiwan, online: Social Science Research Network $<$ http://www.ssrn.com> at 2. 
Taking into consideration Japan's experience with the duty of loyalty, it can be asserted that "even poorly motivated and ill-fitting legal transplant may become a core rule in the host country over time, as the legal infrastructure and political economy change" ${ }^{354}$. It must be noted, that Japan needed about four decades to start employing the duty of loyalty. The reasons why the duty of loyalty transplant failed for so long time are the following. First, the judges and practitioners were not familiar with the use of broad legal standards, which differ from narrowly tailored rules. Second, a standard of loyalty was not developed in Japan. Under civil law, judges are required to apply comprehensive codes mechanically to the cases before them. If a new issue that is not specifically covered in an existing code comes before the court, the judge has little discretionary power to deal with it, regardless of the judge's opinions on the matter ${ }^{355}$. Moreover, court decisions in the civil law system are merely seen as a clarification of the existing law ${ }^{356}$. Thus, if a judge is not familiar with the conception of fiduciary duties and with the standard of the duty of loyalty, he/she would likely try to avoid to use this standard and, instead, try to find some other rules which, somehow, can be used to decide the case. Third, judges could not employ remedies against self-dealing in the absence of explicit statutory guidance. In other words, a court does not have power to make any order it

354 Tamar Frankel, Towards Universal Fiduciary Principles, online: Social Science Research Network <http://www.ssrn.com> at 22.

355 William A Reese, Jr \& Michael S Weisbach, Protection of Minority Shareholder Interests, Cross-listings in the United States, and Subsequent Equity Offerings, online: Social Science Research Network $<$ http://www.ssrn.com $>$ at 5.

${ }^{356}$ H P Glenn, Legal Traditions of the World, 2d ed (England: Oxford University Press, 2004) at 13. 
thinks fit. Fourth, the adoption of the duty of loyalty was wholly motivated by politics. ${ }^{357}$ Some authors, also add that the Japanese legal community itself did not seem concerned to implement the duty of loyalty ${ }^{358}$. To sum up, it can be simply said that Japan was not ready for this legal transplantation. More importantly, Japan did not seem to desire to adopt this institution at the time of transplant.

A similar situation arises with regard to Taiwan (The Republic of China). In 2001, some amendments were made to its Companies Act. ${ }^{359}$ The most significant of these was the introduction of the common law concept of fiduciary duties. As with Japan, Taiwan only introduced a very general concept of the duty of loyalty. Because of this, as Professor Christopher Chen Chao-hung observes, there are some fundamentals flaws associated with this adoption:

First, there is no 'equity' under Taiwan law. Thus, the fiduciary duties must be integrated into the Civil Code and other civil law concepts. Second, Taiwan law did not build on the development of case law. Instead, once a concept is introduced, judges and practitioners will interpret the concepts based on their understanding of the concept rather than on the

${ }^{357}$ See, Hedeki Kanda \& Curtis J Milhaupt, supra note 339 at 12:Article 254-3 (duty of loyalty) of the Commercial Code was imported from the US in 1950.... the US Occupation authorities in charge of corporate law reform sought inclusion of this provision as part of a package of reform designed to improve minority shareholders' rights under the Japanese Commercial Code.

${ }^{358}$ Ibid at 18 .

359 Ministry of Justice, The Companies Act of China, online: Laws and Regulations database of the Republic of China $<$ http://law.moj.gov.tw/Eng/LawClass/LawAll.aspx?PCode=J0080001>, Article 23: The responsible person of a company shall have the loyalty and shall exercise the duty of care of a good administrator in conducting the business operation of the company. 
development of case law in its original source. Third, when introducing the loyalty part of the duty, Taiwan law only introduced the 'concept' of loyalty without any further classification (e.g. self-dealing, corporate opportunity, acting for proper purpose, etc.). This point exacerbates the previous one because there was no substance to the general 'duty of loyalty, 360 .

The biggest problem, which Japan and Taiwan faced, was not being ready for the use of the broad standard of loyalty by most of judges, practitioners and scholars. However, the examples of Japan and Taiwan show the possibility to implement fiduciary duties in the civil law system. The world changes every day, thus the legal theory also has to be changed. This means, for instance, that some new conceptions, principles and rules should be formulated to take the places of old one. In regard to fiduciary duties, implementing them requires making deliberate decisions and taking gradual steps. First, before adopting the duty of loyalty, a host country must undertake preparatory work. This means that all universities, schools for judges, bar societies, etc., have to start teaching about fiduciary duties very seriously. Legal journals, newspaper and news magazines must write articles on this topic. In other words, people have to know about these duties and start being interested in them. It will take much time, but without this step, the institution will develop very slowly, as it was in Japan. It is easier to teach than retrain, thus, it is possible that only a new generation of lawyers (judges and practitioners) will utilize fiduciary duties in the right way. This happens even now, in Japan and Taiwan, when judges consider the duty of loyalty as an integral part of the duty of care ${ }^{361}$. Second,

\footnotetext{
${ }^{360}$ Christopher Chen Chao-hung, supra note 352 at 3-4.

${ }^{361}$ See for example, Tamar Frankel, supra note 353 at 22.
} 
the highest court institution in a host country has to issue general elucidations or recommendations on what the duty of loyalty is, how to employ it, and in which situations. Third, courts should be vested with wider power, than they have in civil law countries now. Fourth, judges must adopt the experience on what the duty of loyalty is, from many common law countries, and not to blindly copy, for example, the American experience. Fifth, many amendments have to be made to the existing law of a host country, especially in regard director liability. Sixth, because the civil law judge cannot "interpret" the laws like his/her colleague from a common law jurisdiction, the monitoring of court decisions from different jurisdictions should be constantly done to offer further explanation to judges. By using all of these steps, it will be possible ensure a successful transplantation of fiduciary duties into a civil law jurisdiction and, hence, protect the rights of shareholders.

So then, not all the above-mentioned remedies can be easily implemented in civil law countries. Problems can arise with fiduciary duties because they are not well developed in civil law countries, and because of limitations on the interpretational power of the courts, that are the primary forums through which to develop these duties. Also, it is almost impossible to adopt the oppression remedy in the same manner that it works in common law countries. The "reasonable expectation" principle cannot be fully utilized in civil law countries because doing so would violate the main principles of the continental law world. Generally speaking, the most unique feature of the oppression remedy, which distinguishes it from the other remedies, is the possibility to bring an application against oppression even when a director or a majority shareholder does not breach any law, but 
acts "unfairly" against the minority. As mentioned, "unfairness" is not recognized in the civil law countries as a cause of action. As such, the oppression remedy cannot work at full capacity in those countries without substantial conceptual changes. Without these changes, the oppression remedy loses its attractiveness. This is because if laws or shareholder's rights are breached, minority shareholders have many remedies to employ. Thus, the uniqueness and comprehensiveness of this remedy are lost, making the remedy equivalent to a direct action in civil law countries. In other words, without adopting the oppression remedy wholly, or in its entirety with the possibility to apply to a court even when there is no breach of law, but only where an action violates reasonable expectation, it will not be worth implementing the remedy at all.

To summarize, to transplant the common law director's duties and the oppression remedy, it would be necessary, first, to make substantial conceptual changes in the doctrines of civil law, rather than simply add these institutions to various national legislations. Only after reconsidering some main civil law principles will it be possible to adopt these institutions for the benefit of shareholders. Otherwise, implementing these institutions (the oppression remedy and the fiduciary duties) into civil law systems will not bring positive results for the minority shareholder, simply because their potential to bring change will be defeated by their incompatibilities with the theoretical bases of civil law.

Even if this analysis is not foolproof, at least, it achieves its objective, which is to highlight the possible problems in adopting these common law remedies into the civil law context. 


\section{CHAPTER V}

\section{CONCLUSION}

For many centuries, scholars from common law and civil law systems have argued about which system is better and which is worse. In respect to minority shareholder protection, it is possible to assert with confidence that the common law system is far ahead of the civil law one. From the author's experience as a practitioner in a civil law country, and from evidence of statistics, judicial practice and legislation, this is, sadly, the reality.

In light of this, it is necessary to implement some institutions or remedies from the common law system in the civil law system. However, from the analysis of the possibility of implementing remedies from the common law system, the plausible conclusion is that not all the remedies can be simply adopted into the civil law system. Other institutions or remedies, such as compulsory cumulative voting in the case of the election of directors and derivative action, could be implemented in civil law legislation without serious impediments. These last two institutions do not conflict with civil law principles and theory. Moreover, adopting them would positively reflect on minority shareholder protection.

Cumulative voting will protect the minority against abuse from majority shareholders. It will also safeguard the balance between the minority and majority. Given the fact that the majority will still prevail in power in a company, compulsory cumulative voting will maintain their interests and status ("Majority Rule"), but it will also give the 
minority the chance to elect a "right director" who will likely support their views and interests. This director will be a minority's "watchdog" and will control the majority and other directors. Overall, cumulative voting will make it more likely for minority shareholders to participate in the management of the corporation and, consequently, enhance the protection of their rights.

The derivative action is an extremely important right or remedy for a minority shareholder. This is because it is one of only a few possible ways by which such a shareholder can protect him/herself and a corporation from managers and majority shareholders. In other words, the derivative action resists and opposes the deficiency of the corporate personality and the principle of "Majority rules". The derivative action also prevents directors from abusing their rights, and forces management to act in the best interest of a corporation, rather than merely in its own interests or in the interests of the majority.

Civil law countries are not familiar with the oppression remedy, which can be extremely useful for minority shareholder protection. The broad understanding and interpretation of this remedy by legislators and judges gives a right to bring an action in different situations and defends against unfair conduct. The positive feature of the oppression remedy is the expanded protection it offers not only against the unlawful actions of a director or majority shareholders, but also against unjust lawful actions. The concept of "reasonable expectation" that the oppression remedy upholds under the common law system puts this system ahead, in comparison to civil law countries. Unfortunately, this concept cannot be simply applied in the civil law system because of 
its incompatibility with its main principles, particularly the ability to bring an action only in the situation when a law or a right is breached. In other words, civil law countries do not recognize the concept of "fairness" or "unfairness"; consequently all actions which are lawful are automatically recognized as legal and fair. Because of this feature, it often happens in the civil law that a minority is not able to protect him/herself. These situations include diluting shares, changing corporate structure to drastically alter debt ratios, paying dividends without a formal declaration, preferring some shareholders with management fees or paying directors' fees higher than the industry norm, improperly reducing a shareholder's dividend, distributing profit as salaries to majority shareholders, or hiring the majority's relatives or trusted persons in order to receive a "kickback". Almost all these actions are totally within the scope of the law and are respectively not prohibited by the law. This is the primary reason a shareholder cannot bring an application to a court to protect his/her rights.

A director's duties in common law countries are also much more elaborate than in civil law countries like Ukraine and Germany. These duties have mainly been elaborated by the judiciary, which continues to do so to offer effective protection to the minority against management and the majority. In common law countries, the duties of directors can simply be defined as having to act in the best interests of the corporation. The best interests of the corporation, in our case, mean the interests of the majority and the minority. Because of this, minority shareholders feel more protected. For example, if a majority approves a decision that totally contradicts the interest of the corporation, the common law director cannot carry out this decision, thereby protecting the interests of the 
minority. However, in civil law countries, a shareholders' meeting is the supreme organ of a corporation, and its decision is compulsory for management to carry out. Failure to carry out such a decision means a director breaches his/her duty of obedience, and he/she will be liable to suit.

Though the common law regimes are not perfect in protecting minority shareholders, they still offer a good example for the civil law countries to emulate. In the end, the recommendations made in this thesis to adopt common law remedies, and to think about reconceptualizing relevant foundational principles of the civil law to accommodate others, has one purpose. That purpose is to shed some light on how to improve corporate governance in the civil law system, and in particular, how to better protect minority shareholders in those countries. 


\section{BIBLIOGRAPHY}

\section{LEGISLATION}

Alberta Business Corporation Act, RSA 2000, c B-9.

British Columbia Company Act, RSBC 1996, c 62.

Canada Business Corporation Act, RSC 1985, c C-44.

Civil Code of Ukraine, 16.01.2003 № 435-IV, Official website of the Verkhovna Rada of Ukraine (Parliament) <http://www.rada.gov.ua $>$ [translated by author].

Civil Procedural Code of Ukraine, 18.03.2004 № 1618-IV, online: Official website of the Verkhovna Rada of Ukraine (Parliament) <http://www.rada.gov.ua $>$ [translated by author].

Commercial Code of Ukraine, 16.01.2003 № 436-IV, online: Official website of the Verkhovna Rada of Ukraine (Parliament) <http://www.rada.gov.ua $>$ [translated by author].

Commercial Procedural Code of Ukraine, 06.11.1991 № 1798-XII, online: Official website of the Verkhovna Rada of Ukraine (Parliament) $<$ http://www.rada.gov.ua $>$ [translated by author].

Companies Act 2006 (UK), c 46.

Companies Act, 1948 (UK), 11 \& 12 Geo VI, c 38. 
German Civil Code (Bürgerliches Gesetzbuch), online: German Federal Ministry of Justice $<$ http://www.gesetze-im-internet.de/englisch_bgb $>$.

Labor Code of Ukraine, 10.12.1971 № 322-VIII, online: Official website of the Verkhovna Rada of Ukraine (Parliament) <http://www.rada.gov.ua $>$ [translated by author].

Law “On Business Associations”, 19.09.1991 № 1576-XII, online: Official website of the Verkhovna Rada of Ukraine (Parliament) <http://www.rada.gov.ua $>$ [translated by author].

Law “On Joint Stock Companies of Ukraine”, 17.09.2008 № 514-VI, online: Official website of the Verkhovna Rada of Ukraine (Parliament) $<$ http://www.rada.gov.ua $>$ [translated by author].

Law “On Securities and Stock Exchange”, 23.02.2006 № 3480-IV, online: Official website of the Verkhovna Rada of Ukraine (Parliament) $<\mathrm{http}: / /$ www.rada.gov.ua $>$ [translated by author].

Nova Scotia Companies Act, RSNS 1989, c 81.

Ontario Business Corporation Act, RSO 1990, c B. 16. 
Presidium of Supreme Commercial Court of Ukraine, Recommendation from 28.12.2007 № 04-5/14 "Regarding the practice of the implementation of legislation during litigation proceedings occur from corporate relations", online: Official website of the Verkhovna Rada of Ukraine (Parliament) <http://www.rada.gov.ua $>$ [translated by author].

The Private Limited Companies Act (Gesetz betreffend die Gesellschaftcn mit beschrankter Haftung), online: German Federal Ministry of Justice $<$ http://www.archive.org/stream/germancommercial00germuoft/germancommerci al00germuoft_djvu.txt>.

\section{JURISPRUDENCE}

820099 Ontario Inc v Harold E Ballard Ltd, [1991] OJ No 266, 25 ACWS (3d) 853, 1991 CarswellOnt 142.

Apotex Inc v Laboratories Fournier S A, [2006] OJ No 4555 (QL).

Awad v Dover Investments Ltd (2004), 47 BLR (3d) 55.

BCE v 1976 Debentureholders, 2008 SCC 69, [2008] 3 SCR 560.

Brant Investments Ltd v KeepRite Inc, 37 BLR 65, 60 OR (2d) 737, 42 DLR (4th) 15.

Brinson Ry v Exchange Bank, 16 Ga App 425, 85 SE 634 (1915). 
Bristol and West Building Society v Mothew, [1996] 4 All ER 698.

Burton v Exxon Corporation, 583 F Supp 405 (1984).

Canadian Aero Services Ltd v O'Malley, [1974] SCR 592.

Cook v Deeks, [1916-17] All ER Rep 285, [1916] 1 AC 554.

Dodge v Ford Motor Company, 204 Mich 459, 170 NW 668 (1919).

Dovey v Cory, [1901] AC 477 (HL).

Downtown Eatery (1993) Ltd v Ontario, 2001 CarswellOnt 1680 (WL Can).

Duha Printers (Western) Ltd v Canada, [1998] 1 SCR 795.

Ebrahimi v Westbourne Gallereies Ltd, [1972] 2 All ER 492.

Edwards v Halliwell [1950] 2 All ER 1064 (CA).

Equitable Life Insurance Society v Bowley, [2003] EWCA Civ 1114, [2003] 2 BCLC 603 (EWCA).

Exide Canada Inc v Hilts (2005), 11 BLR (4th) 311 (SCJ).

Fiorillo v Krispy Kreme Doughnuts, Inc, [2009] OJ No 2430, 60 BLR (4th) 113.

First Edmonton place ltd v 315888 Alberta Ltd, [1988] AJ no 511 (QL).

Foss v Harbottle (1843), 2 Hare 461, 67 ER 189. 
Gay v Gay's Super Markets Inc, 343 A (2d) 577 (1975).

Gerald Bonavita v Alan Corbo and Corbo Jewelers Inc, 300 NJ Super 179, 692 A (2d) 119 (1996).

Hely-Hutchinson v Brayhead Ltd and Another [1967] 3 All ER 98.

Hess v Proudfoot Motels Ltd, [1992] OJ No 4189 (QL) (Ont Ct J).

Hutton v West Cork Ry, (1883) 23 Ch D 654.

ITT-decision (1975) 65 BGHZ 15 (Germany).

Jerryv Gillard, [2005] AJ № 104 (QL) (QB).

Judgment of Apr. 1, 1953, 9 BGHZ (Germany).

Kaye v Croydon Tramways Co [1898] 1 Ch 358.

Lagunas Nitrate Co v Lagunas Syndicate [1899] 2 Ch 392 at 435.

Luxembourg Ry Co v Magnay (No 2), (1858), 25 Beav 586.

McAteer v Devoncroft Developments Ltd, [2001] AJ No1481, 2001 ABQB 917.

Nagy v Riblet Prods Corp, 79 F (3d) 572 (1996).

Naneff v Con-Crete Holding Ltd (1995), 23 OR (3d) 481. 
Pente Investment Management Ltd v Schneider Corp (1998), 42 OR (3d) 177, [1998] OJ No 4142 (Ont CA).

Peoples Department Stores (Trustee of) v Wise, 2004 SCC 68.

Peso Silver Mines Ltd v Cropper, [1966] SCR 673.

Piller Sausages \& Delicatessens Ltd v Cobb International Corp, [2003] OJ No 2647 (QL).

Placer Dome Canada Ltd v Ontario (Minister of Finance), [2006] 1 SCR 715.

Prima Computer of Canada Ltd v Jeffre, [1991] OJ No 2317 (QL).

$R v$ Sands Motor Hotel Ltd, [1984] SJ No 56 (QL).

Re Brazilian Rubber Plantations and Estates, Ltd, [1911] 1 Ch 425.

Re Cape Breton Co (1884), 26 Chd 221.

Re City Equitable Fire Insurance Company Limited, [1925] Ch 407, [1924] All ER REP 485.

Redkop v Robco Construction Ltd (1978) 89 DLR (3d) 507, 5 BLR 58 (BCSC).

Revlon, Inc v MacAndrews \& Forbes Holding, 506 A (2d) 173 (Del 1986).

Royal Trust Corp of Canada v Hordo, [1993] OJ No 1560 (QL). 
Salomon v Salomon \& Co, [1897] AC 22 HL (Eng).

Scottish Co-operative Society v Meyer, [1959] AC 324.

Simpson v Westminster Hotel Co (1860) 8 HLC 712.

Transvaal Lands Co v New Belgium (Transvaal) Land and Development Co [1914-15] All ER Rep 990, [1914] 2 Ch 505.

Tremblett v SCB Fisheries, Ltd (1993), 116 Nfld \& PEIR 139 (Nfld SC).

Trillium Computer Resources Inc v Taiwan Connection Inc (1992), 10 OR (3d) 249.

Unocal Corporation v Mesa Petroleum Co, 493 A 2d 946 (Del Sup Ct 1985).

Westfair Food Ltd v Watt (1991), 26 ACWS (3d) 361.

Wilkes v Springside Nursing Home Inc, 370 Mass 842, 353 NE (2d) 657 (1976).

Winfield v Daniel, 2004 CLB 12084, 21 Alta LR (4th) 337, [2004] AJ № 37, 2004 ABQB 40.

\section{SECONDARY MATERIAL: MONOGRAPHS}

Beck, Stanley. Minority Shareholders' Rights in the 1980, Special Lectures of the Law Society of Upper Canada, Corporate Law in the 1980s (Don Mills, Ont: R De Boo, 1982). 
Belov, V A, Securities in Russian Civil Law ((Moscow: UrInfoR, 1996) [translated by author].

Berle, Adolf \& Gardiner Means, The Modern Corporation and Private Property (New York: Macmillan, 1932).

Berle, Adolf. The $20^{\text {th }}$ Century Capitalist Revolution (New York: Harcourt, Brace, 1954).

Berle, Adolph \& Gardiner Means. The Modern Corporation and Private Property (New York, Harcourt, Brace \& World, 1968).

Bernd, Ruster. Business Transactions in Germany (New York: Looseleaf, 1983, New York).

Bradley, Sarah. Nova Scotia Companies Act \& Commentary (Markham, Ontario: LexisNexis Canada, 2012).

D V Bobrova, O V Dzera. Civil Law of Ukraine: Textbook: 2 volumes (Kyiv: Jurincom Inter, 1999) [translated by author].

Dickerson, Robert WV, John L Howard \& Leon Getz. Proposals for a New Business Corporations Law (Ottawa: Information Canada, 1971).

Dornseifer, Frank. Corporate Business Forms in Europe: A Compendium of Public and Private Limited Companies in Europe (Munich: Sellier European Law Publishers, 2005). 
Erchlentz, Enno W. Modern German Corporation Law: Volume I (New York: Oceana Publications Inc, 1979).

Faleev, Vitaliy Victorovich. Minorities Shareholders: status, rights and its performing (Candidate of Legal Science Dissertation, Moscow State Juridical Academy, 2009).

Fischer, Robert et al. GmbH-Gesetz: Kommentar (Koln: O Schmidt, 1987).

Glenn, H P. Legal Traditions of the World, 2d ed (England: Oxford University Press, 2004) at 13.

Hamilton, Robert \& Richard Booth. Business Basics for Law Students: Essential Terms and Concepts, 2d ed (New York: Aspen Publishers, 1998).

Jhering, Rudolf von \& John Lalor. The Struggle for Law (Chicago: Callaghan and Company, 1915).

Ji, Jianfeng. Protecting Minority shareholders in private corporations: A comparative study from Canadian and Chinese Perspectives (LLM Thesis, University of British Columbia, 2010) [unpublished].

Koehnen. Oppression and Related Remedies, (Toronto: Thomson Carswell, 2004).

Kraakman, Reinier et al. The anatomy of corporate law: A comparative and Functional Approach (New York: Oxford University Press, 2004). 
Kravchenko, Rostislav Sergeyevich. Ensuring and Protecting Shareholders' Rights to Information in the Process of Corporate Management (Candidate of Legal Science Thesis, Moscow State Institute of International Relations (MGIMO University), 2001) [translated by author].

McGuiness, Kevin P. Canadian Business Corporation Law, 2nd ed (Markham, Ontario: LexisNexis Canada Inc, 2007).

Morritt, David S, Sonia L Bjorkquist \& Allan D Coleman. The Oppression Remedy (Aurora. ON: Canada Law Book, 2004).

Muller, Klaus. The GmbH: A Guide to the German Limited Liability Company, 3d ed (Germany: Beck; Kluwer Law International, 2006).

Oliver, M C. The Private Company in Germany: A Translation and Commentary (Estover, Plymouth: MACDONALD AND EVANS LIMITED, 1976).

Posner, Richard A. The Economics of Justice (Cambridge, Massachusetts and London, England: Harvard University Press, 1981).

Robert Frank. Creditors' Use of the Oppression Remedy (LLM Thesis, McGill University, 2000) [unpublished]. 
Sabodosh, Roman. Lection III, Corporate Management in Joint Stock Company" (part 3 The Executive Organ) (2010) [unpublished, archived at Kyiv National University named after Taras Shevchenko, Faculty of Law], [translated by author].

Shevchenko, J M et all. Commentary to Civil Code of Ukraine, (Kyiv, Ukraine: Concern “Vidavnichy Dim “In Jure”, 2004) [translated by author].

Sullivan, Ruth \& Elmer Driedger. Driedger on the Construction of Statutes, 3d ed (Toronto: Butterworths, 1994).

Szentkuti, Daniel. Minority shareholder protection rules in Germany, France and in the United Kingdom: A comparative overview (LLM Thesis, Central European University, 2007 [unpublished

Treblicock, Michael. "Economic Analysis of Law" in Richard Devlin ed, Canadian Perspectives on Legal Theory (Toronto: Emond-Montgomery Publishing Ltd, 1991).

Treschinskaya, Yuliya. Protection of members of Limited Liability Companies in Ukraine in comparison with Germany (LLM Short Thesis, Central European University, 2008) [unpublished].

UK, HC. "Report of the Company Law Committee" (Jenkins Committee), Cmnd 1749 in Sessional Papers 1961-1962. 
University of Alberta. Proposals for a new Alberta Business Corporations Act (Report No 36) (Edmonton, Alberta: Institute of Law Research and Reform, 1980).

Vinnik, O. Commercial Law in Ukraine (Kyiv: Jurincom-Inter, 2008) [translated by author].

Welling, Bruce. Corporate Law in Canada: the Governing Principles, 3rd ed (Mudgeeraba, Australia; London ON: Scribblers Publishing, 2006).

Wolters Kluwer, The Nature of Shares, online: Wolter Kluwer Russia $<$ http://www.wolters-kluwer.ru/ai/book.26829/file_chapt/g267.pdf $>$ [translated by author].

\section{SECONDARY MATERIAL: ARTICLES}

Aslan, Hadiye. "Controlling Shareholders and the Agency Cost of Debt: Evidence from Syndicated Loans", online: Social Science Research Network $<\mathrm{http}: / /$ www.ssrn.com>.

Ben-Ishai, Stephanie \& Poonam Puri. "The Canadian Oppression Remedy Judicially considered: 1995-2001" (2005) 30 Queen's LJ 79

Berle, Adolf. "For Whom Corporate Managers are Trustees: A Note in Harvard Law Review”, (1932) 45 Harv L Rev 1365. 
Berle, Adolph. "Corporate Powers as Power in trust" (1931) 44 Harv L Rev 1049.

Bradley, Sarah. "BCE Inc. v. 1976 Debentureholders: The new fiduciary duties of fair treatment, statutory compliance, and good corporate citizenship" (2010) 41:2 Ottawa L Rev Summer 325.

Braendle, Udo "Shareholder Protection in the USA and Germany - "Law and Finance" Revisited", (2006) 7:3 German Law Journal 257.

Bratton, William \& Michael Wachter. Shareholder Primacy's Corporatist Origins: Adolf Berle and 'The Modern Corporation', online: Social Science Research Network $<$ http://www.ssrn.com>.

Brudney, Victor. "Dividends, Discretion, and Disclosure" (1980) 66:1 VA L REV 85.

Chao-hung, Christopher Chen. Transplantation of Duties into Civil Law Jurisdiction: Experiences from Taiwan, online: Social Science Research Network $<\mathrm{http}: / /$ www.ssrn.com>.

Chernichlaw, Adam. "Oppressed Shareholders in Close Corporation: A Market Oriented Statutory Remedy" (1997) 16 Cardozo L Rev 501.

Conac, Pierre-Henri, Luca Enriques \& Martin Gelter. Enforcing self-dealing Constrains on Dominant Shareholders in Europe, online: University of California, Berkley $<$ http://escholarship.org/uc/item/5fp568xk\#page-1>. 
Cooper, Rob. Inside Apple's Chinese 'sweatshop' factory where workers are paid just $£ 1.12$ per hour to produce iPhones and iPads for the West, online: Mail Online $<\mathrm{http}: / /$ www.dailymail.co.uk $>$.

DeMott. "Oppressed but not Betrayed: A Comparative Assessment of Canadian Remedies for Minority Shareholders and other Corporate Constituents" (1993) 56Law \& Contemp Probs 181.

Dodd, Merrick. "For whom are corporate managers trustees?" (1932) 45 Har L Rev 1145.

Dodd, Merrick. "Is Effective Enforcement of the Fiduciary Duties of Corporate Managers Practicable?" (1935) 2 U Chi L Rev 194.

Dodd, Merrick. "Modern Corporation, Private Property and Recent Federal Legislation (1941) 54:6 Harv L Rev 917.

Doing Business, Economy rankings, online: Doing business $<\mathrm{http}: / /$ www.doingbusiness.org $>$.

Fischel, Daniel R. "The Law and Economics of Dividend Policy”, 67 VA. L. REV. 699, 715-17 (1981).

Frankel, Tamar. Towards Universal Fiduciary Principles, online: Social Science Research Network <http://www.ssrn.com>.

Hay, R \& L Smith. "The Unanimous Shareholder Agreement: A New Device for Shareholder Control" (1985) 10 Can LJ 440. 
Himler, Peter. Apple Taxes and PR, online: Forbes $<\mathrm{http}$ ://www.forbes.com $>$.

Johnson, Simon et al, “Tunneling” (2000) 90 Am Econ Rev 22.

Kanda, Hedeki \& Curtis J Milhaupt. Re-examining Legal Transplants: The Director's Fiduciary Duty in Japanese Corporate Law, online: Social Science Research Network $<$ http://www.ssrn.com>.

Kleindiek, Detlef. "Protection of Minority Shareholders under German Law" (1193) 4 Int'l Co \& Com L Rev 138.

Kline, Carol. "Protecting Minority Shareholders in Close Corporations: Modeling Czech Investor Protections on German and United States Law" (2000) 23:2 BC Int'l \& Comp L Rev 229.

Kuras, Ruth. "Corporate Social Responsibility: A Canada-U. S. Comparative Analysis" (2002) 28 Man LJ 303.

Mendoza, Jose Miguel. "The Controlling Shareholder as Reputational Intermediary", online: Saïd Business School, University of Oxford $<$ http://www.sbs.ox.ac.uk/centres/reputation/Documents/10-302-

The\%20Controlling\%20Shareholder\%20as\%20Reputational\%20Intermediary.pdf $>$. 
Miller, Sandra. "Minority Shareholder Oppression in the Private Company on the European Community: A Comparative Analysis of German, United Kingdom and French “Close corporation problem” (1997) 30 Cornell Int'1 LJ 381.

Millon, David. “Theories of the corporation” (1990) 1990 Duke LJ 201.

Milnes, Robert E \& Kathleen M. Ritchie. Directors' and Officers' Duties and Liabilities, online: Gowling Henderson Lafleur $<$ http://www.gowlings.com/resources/PublicationPDFs/MilnesR_DirectorsMemo 10.pdf $>$.

Moll, Douglas K. "Shareholder Oppression \& Dividend Policy in the Close Corporation", (2003) 60 Wash \& Lee L Rev 841.

Olin John \& Ronald J. Gilson. "Controlling Shareholders and Corporate Governance: Complicating the Comparative Taxonomy”, online: Social Science Research Network $<$ http://www.ssrn.com $>$.

Porta, R La et all. "Law and Finance" (1998) 106 J Pol Econ 1113.

Posner, Richard A. "The Ethical and Political Basis of the Efficiency Norm in Common Law Adjudication" (1980) 8 Hofstra L Rev 487.

Raice, Shaydi. "Facebook Sets Historic IPO", online: The Wall Street Journal $<$ http://online.wsj.com>. 
Reese, William A, Jr \& Michael S Weisbach. Protection of Minority Shareholder Interests, Cross-listings in the United States, and Subsequent Equity Offerings, online: Social Science Research Network <http://www.ssrn.com>.

Roe, Mark. "The Shareholder Wealth Maximization Norm and Industrial Organization" (2001) 149 U Pa L Rev 2063.

Scogin, Hugh. "Withdrawal and Expulsion in Germany: A Comparative Perspective on the "Close Corporation Problem" (1993) 15 Mich J Int'l L 127.

Standard and Poor's. General rules of ratings criteria to assess a company, Rating criteria, online: Standard and Poor's $<$ http://www.standardandpoors.com>.

Stout, Lynn A. "Bad and not-so-bad Arguments for Shareholder Primacy", (2002) 75 Southern Cal L Rev 1189.

Stout, Lynn A. "The Mythical Benefits of Shareholder Control”, online: Harvard Law School $<$ http://www.law.harvard.edu/faculty/bebchuk/pdfs/07_response_Stout.pdf $>$.

Tax Jurisdictions, Liechtenstein: Types of Company, online: LOWTAX: Global Tax \& Business Portal $<\mathrm{http}: / /$ www.lowtax.net/lowtax $/ \mathrm{html} / \mathrm{jlicos}$.html\#trust $>$.

United Nations Conference on Trade and Development, World Investment Report 2012: Towards a New Generation of Investment Policies, online: UNCTAD $<$ http://unctad.org $>$. 
Vasudev, P M. Stakeholders in the CBCA: An Appraisal and Some Proposals, online: Social Science Research Network <http://www.ssrn.com>.

Vinnik, O, "On the Question about the Improvement of the Business Associations in Ukraine" (2000) 9 Pravo Ukraini 39 [translated by author].

Watson, Alan. "Aspects of Reception of Law” (1996) 44 Am J Comp L 335 at 335.

Weiner, Joseph. "The Berle-Dodd Dialogue on the Concept of the Corporation" (1964) 64 Colum L Rev 1458.

Worstall, Tim. Chinese Workers Get Only \$8 From Each Apple iPad 2, online: Forbes $<$ http://www.forbes.com>. 